\title{
New species of Araceae from the Río Cenepa region, Amazonas Department, Perú
}

\author{
Thomas B. Croat ${ }^{1,2}$, Anne Swart ${ }^{3}$ \& Emily D. Yates $^{1}$
}

\begin{abstract}
(New species of Araceae from the Río Cenepa region, Amazonas Department, Perú) New species from the Department of Amazonas in Peru are described as new in preparation for the treatment of the Araceae for the Flora del Cenepa y Areas Adyacentes Amazonas Peru. New species include: Anthurium apanui Croat, A. atamainii Croat, $A$. baguense Croat, $A$. brent-berlinii Croat, $A$. ceronii Croat, $A$. chinimense Croat, $A$. diazii Croat, A. galileanum Croat, A. huampamiense Croat, $A$. huashikatii Croat, $A$. kayapii Croat, $A$. kugkumasii Croat, $A$. kusuense Croat, $A$. leveauii Croat, $A$. lingulare Croat, $A$. mostaceroi Croat, $A$. penae Croat, A. quipuscoae Croat, A. rojasiae Croat, A. shinumas Croat, $A$. tsamajainii Croat, $A$. tunquii Croat, $A$. yamayakatense Croat, Dieffenbachia wurdackii Croat, Monstera aureopinnata Croat, M. cenepensis Croat, M. vasquezii Croat, Philodendron ampamii Croat, $P$. ancuashii Croat, $P$. barbourii Croat, $P$. brent-berlinii Croat, $P$. condorcanquense Croat, $P$. avenium Croat, $P$. huashikatii Croat, $P$. palaciosii Croat, $P$. reticulatum Croat, $P$. swartiae Croat, Rhodospatha acosta-solisii Croat, $R$. brent-berlinii Croat, $R$. katipas Croat, $R$. piushaduka Croat, Spathiphyllum barbourii Croat, S. brent-berlinii Croat, S. buntingianum Croat, S. diazii Croat, Stenospermation ancuashii Croat, S. parvum Croat \& A. P. Gómez, Xanthosoma baguense Croat. Key-words: Araceae, new species, Río Cenepa, Perú, Amazonas Department.

Resumo

(Novas espécies de Araceae da região do rio Cenepa, Departamento de Amazonas, Peru) Durante a elaboração da flora de Araceae do rio Cenepa e áreas adjacentes, Amazonas, Peru, várias novas espécies foram encontradas e são aqui descritas. São elas: Anthurium apanui Croat, $A$. atamainii Croat, $A$. baguense Croat, A. brent-berlinii Croat, $A$. ceronii Croat, $A$. chinimense Croat, $A$. diazii Croat, A. galileanum Croat, $A$. huampamiense Croat, $A$. huashikatii Croat, $A$. kayapii Croat, $A$. kugkumasii Croat, $A$. kusuense Croat, $A$. leveauii Croat, A. lingulare Croat, A. mostaceroi Croat, A. penae Croat, A. quipuscoae Croat, A. rojasiae Croat, A. shinumas Croat, A. tsamajainii Croat, A. tunquii Croat, A. yamayakatense Croat, Dieffenbachia wurdackii Croat, Monstera aureopinnata Croat, M. cenepensis Croat, M. vasquezii Croat, Philodendron ampamii Croat, $P$. ancuashii Croat, $P$. barbourii Croat, $P$. brent-berlinii Croat, $P$. condorcanquense Croat, $P$. avenium Croat, $P$. huashikatii Croat, $P$. palaciosii Croat, $P$. reticulatum Croat, $P$. swartiae Croat, Rhodospatha acosta-solisii Croat, $R$. brent-berlinii Croat, $R$. katipas Croat, $R$. piushaduka Croat, Spathiphyllum barbourii Croat, S. brent-berlinii Croat, S. buntingianum Croat, S. diazii Croat, Stenospermation ancuashii Croat, S. parvum Croat \& A. P. Gómez, Xanthosoma baguense Croat.

Palavras-chave: Araceae, espécies novas, rio Cenepa, Peru, Amazonas.
\end{abstract}

\section{INTRODUCTION}

New species of Araceae, in the genera Anthurium, Dieffenbachia, Monstera, Philodendron, Rhodospatha, Spathiphyllum, Stenospermation, and Xanthosoma, are described as new from the area of the Río Cenepa and Río Santiago drainages in northwestern Peru. Included are 48 new species described in preparation for the treatment of the Araceae for the Flora del Cenepa y Areas Adyacentes Ama- zonas Peru (Croat et al., in press). The Río Cenepa flora area lies between the Río Cenepa and the Río Santiago in Bagua or Condorcanqui provinces at $\mathrm{ca} .4^{\circ} 00^{\prime} \mathrm{S}$ to $5^{\circ} 30^{\prime} \mathrm{S}$ and $77^{\circ} 30^{\prime} \mathrm{W}$ to $78^{\circ} 30^{\prime} \mathrm{W}$ at ca. 500 $1500 \mathrm{~m}$ elevation. This area encompasses the following life zones based on the Holdridge Life Zone system (Holdridge 1971): Premontane rain forest (P-rf), Tropical wet forest (T-wf), and Premontane moist forest

Artigo recebido em 11/2004. Aceito para publicação em 06/2005.

${ }^{1}$ Missouri Botanical Garden. P.O. Box 299. St. Loius, MO 63166-0299, USA.

${ }^{2}$ e-mail: Thomas.Croat@mobot.org

${ }^{3}$ Washington University, St. Louis, MO. 
transitioning to Tropical moist forest (P-mf/ T).

Anthurium apanui Croat, sp. nov. Type: Perú. Amazonas: Bagua, Imaza, Marañon, Yamayakat, Kusu-Chapi, Río Marañon, permanent area $500 \times 500 \mathrm{~m}$, parcel "E," $4^{\circ} 55^{\prime} \mathrm{S}, 78^{\circ} 19^{\prime} \mathrm{W}, 550 \mathrm{~m}$, Feb. 1995, $R$. Vasquez, N. Jaramillo, R. Apanu \& R. Kugkumas 20067 (holotype, MO-05002341). Fig. 1a.

Planta epiphytica; internodia brevia, 8 mm diam. in sicco; cataphylla $5.5 \mathrm{~cm}$ longa; petiolis $18-19 \mathrm{~cm}$ longus; laminae oblongae vel oblongato-ellipticae, $33.5-34.5 \mathrm{~cm}$ longae, $7.3-7.6 \mathrm{~cm}$ latae; nervis primariis lateralibus 5-6 utroque; pedunculus $22 \mathrm{~cm}$ longus, 1-2 mm diam. in sicco; spatha viridis; spadice viridis, cylindricus, $4 \mathrm{~cm}$ longus, ca. $4 \mathrm{~mm}$ diam. in sicco.

Epiphytic plant; internodes short, drying $8 \mathrm{~mm}$ diam.; cataphylls $5.5 \mathrm{~cm}$ long, drying tan, weathering to fine longitudinal fibers near apex, a reticulum near base at upper nodes, then deciduous. Petioles 18-19 $\mathrm{cm}$ long, drying 2-3 $\mathrm{mm}$ diam., dark yellowish brown; blades oblong to oblongelliptic, narrowly acuminate at apex (acumen ca. $3.5 \mathrm{~cm}$ long), cuneate at base, 33.5-34.5 $\times 7.3-7.6 \mathrm{~cm}, 4.5-4.6$ times longer than broad, green-tinged with brown or gray above, brown-tinged with yellow below; midrib convex, brown above, convex, concolorous below; primary lateral veins 56 per side, arising at a $42-50^{\circ}$ angle from midrib; collective veins arising from margin near base, 4-5 $\mathrm{mm}$ from margin. Inflorescence with peduncle $22 \mathrm{~cm}$ long, drying 1-2 mm diam.; spathe green; spadix green, cylindrical, erect, $4 \mathrm{~cm}$ long, drying ca. $4 \mathrm{~mm}$ diam. Flowers $2.2-2.3 \times 2.1-2.2$ $\mathrm{mm}, 3$ visible per spiral; lateral tepals $1 \mathrm{~mm}$ wide.

Anthurium apanui is endemic to the type locality in northern Perú at $550 \mathrm{~m}$ in Tropical wet forest (T-wf) or Premontane rain forest (P-rf) life zones (Holdridge 1971). It is a member of section Porphyrochitonium and is characterized by oblong-elliptic, bicolorous blades and a green spadix with only three flowers per spiral. Anthurium apanui is similar to A. tunquii Croat (also published in this manuscript), but the latter species has more, closer primary lateral veins, longer cataphylls, and a red spadix.

This species is named for one of the collectors of the type specimen, Ricardo Apanu Nampin, a chief at Yamayakat Aguruna community along the Marañon river. $\mathrm{He}$ was an assistant plant collector with Rodolfo Vasquez in northern Peru from 1995-1996.

Anthurium atamainii Croat, sp. nov. Type: Perú. Amazonas: Bagua, Imaza, Aguaruna Putuim, anex Yamayakat, zone of high hills $24^{\circ}$ SW of Putuim, 660-760 m, 21 Sep. 1994, C. Díaz, A. Peña, P. Atamain 7179 (holotype, MO-05095096; isotypes, K, US, USM).

Fig. $1 b$.

Planta terrestris; internodia brevia, $0.6-$ $1 \mathrm{~cm}$ diam.; cataphylla 7-9.5 cm longa; petiolis 22.5-38.4 cm longi, 3-4 mm diam.; laminae ovatae vel ovatae-ellipticae, attenuatae ad basim, 27.5-36 cm longae, 7.5$10.8 \mathrm{~cm}$ latae; nervis primariis lateralibus 12-17 utroque; pedunculus 25-34 cm longus; spatha oblonga, 3.7-5.5 cm longa; spadice viridis, cylindroideus, 3.9-7 cm longus, 3-4 mm diam. in sicco.

Terrestrial; internodes short, drying $0.6-1 \mathrm{~cm}$ diam.; cataphylls $7-9.5 \mathrm{~cm}$ long, drying dark reddish brown, lanceolate, persisting at upper internodes, weathering to tan longitudinal fibers near apex, and a reticulum of fibers near base. Petioles 22.5$38.4 \mathrm{~cm}$ long, averaging $30.4 \mathrm{~cm}$, drying 3-4 $\mathrm{mm}$ diam., sulcate adaxially, darkened or grayish brown, sometimes yellow-tinged; geniculum slightly thicker than petiole, sometimes blackened, 1-2 cm long, drying 2-4 mm wide; blades ovate to ovate-elliptic, rarely weakly falcate, sometimes markedly arched along midrib, sometimes inequilateral (one side up to $1 \mathrm{~cm}$ wider than the other), gradually long-acuminate at apex (acumen 2$4 \mathrm{~cm}$ long), base slightly attenuate, $27.5-36$ 

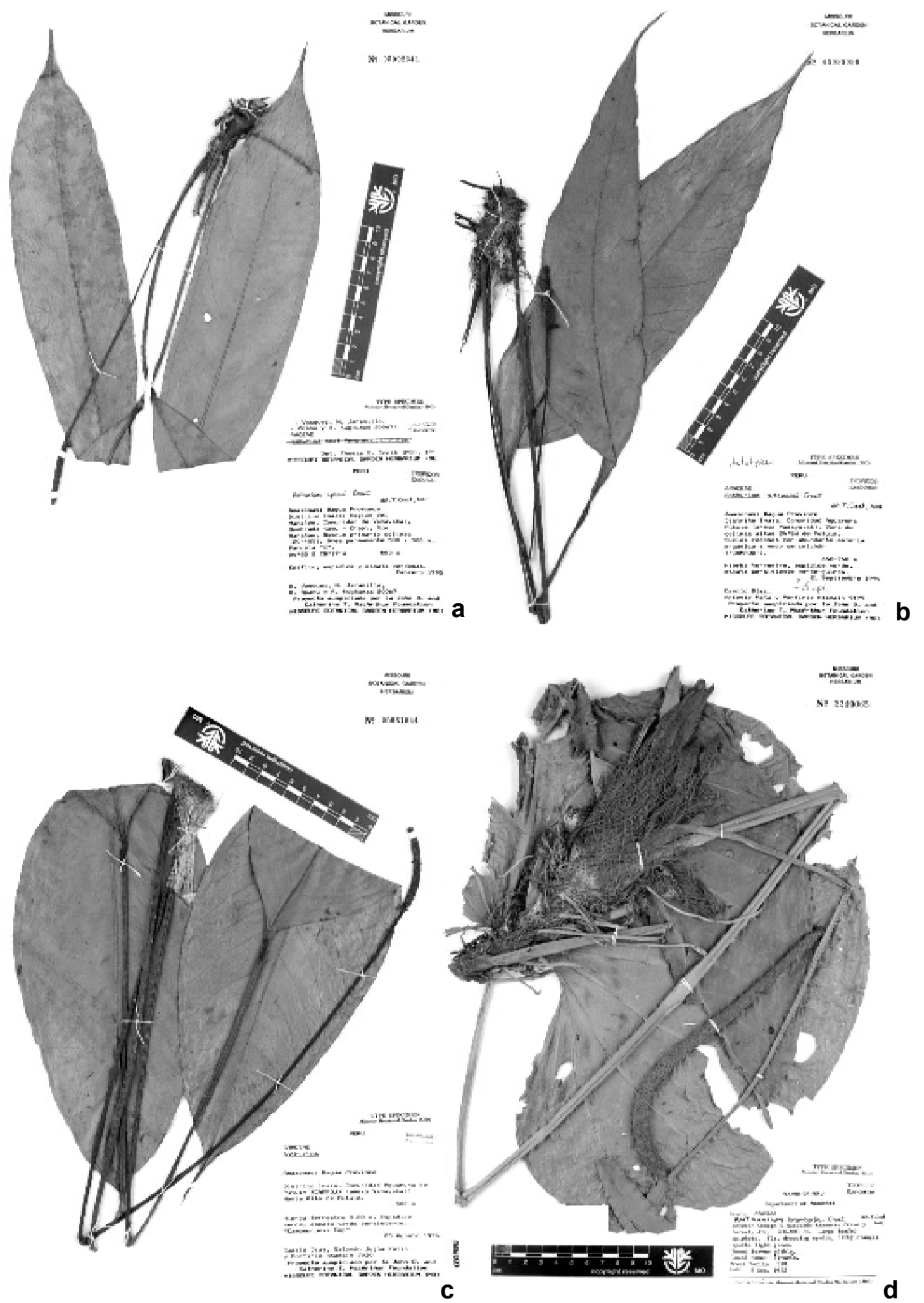

Figure 1 - a. Anthurium apanui Croat. Type specimen. (Vásquez et al. 20067); b. Anthurium atamainii Croat. Type specimen. (Díaz et al. 7179); c. Anthurium baguense Croat. Type specimen. (Díaz et al. 7030); d. Anthurium brentberlinii Croat. Type specimen. (Berlin 518) 
cm long (averaging $31.2 \mathrm{~cm}$ ), $7.5-10.8 \mathrm{~cm}$ wide, 3-4.4 times longer than wide, blade 0.8-1.1 times longer than petiole, revolute at margins, drying eglandular, brownish green above, densely but somewhat faintly glandular-punctate, semi-glossy, grayish brown below; midrib broadly convex, drying 2-4 $\mathrm{mm}$ diam., sometimes slightly wider towards base, concolorous or slightly darker above, convex to narrowly convex, drying $2-3 \mathrm{~mm}$ wide, sometimes slightly wider towards base, concolorous or slightly paler below; primary lateral veins $12-17$ per side, $1-3 \mathrm{~cm}$ apart, departing midrib at a $55-65^{\circ}$ angle, sometimes arising at an acute angle and then spreading, somewhat loop-connected, concolorous above, concolorous and prominent below; collective veins usually arising from base, more prominent than primary lateral veins, $2-7 \mathrm{~mm}$ from margin. Inflorescence with peduncle $25-34 \mathrm{~cm}$ long (averaging $30 \mathrm{~cm}$ ), drying 2-3 mm diam., 0.81.1 times the length of the petiole, medium to light brown; spathe spreading to reflexedspreading, green to green-red, oblong, 3.7$5.5 \mathrm{~cm}$ long, abruptly acuminate; spadix green, cylindroid, sometimes very slightly tapered, erect, sometimes with a slight curve toward the spathe, 3.9-7 cm long, drying 3-4 $\mathrm{mm}$ diam. Flowers $2.7-2.8 \times 2.1-2.8 \mathrm{~mm}, 3-$ 4 visible per spiral; lateral tepals $1.2 \mathrm{~mm}$ wide, outer margins 2-sided.

Anthurium atamainii is known from northern Perú at 430-800 m in Premontane wet forest (P-wf) and Tropical moist forest (T-mf) life zones (Holdridge 1971). It is a member of section Porphyrochitonium and is characterized by ovately shaped blades with a very long acumen. Anthurium atamainii is similar to A. yamaykatense Croat (published herein), but that species has very prominently loop-connected collective veins, longer cataphylls, and a more elliptic blade.

Diaz et al. $7725 \mathrm{~A}$ differs from other collections of $A$. atamainii in having a narrower blade, yet is likely to also be this species and we have included it here. An undetermined collection (C. Diaz et al. 1359) from Loreto, Alto Amazonas, is similar to $A$. atamainii, however, it likely represents another new species.

Anthurium atamainii is named in honor of Porfirio Atamain, an indigenous Aguaruna Indian, and one of the collectors of the type specimen. This specimen was collected while he was an assistant plant collector for the Flora of Río Cenepa project with Rodolfo Vasquez from 1995-1997.

Paratypes: PERU. AMAZONAS: Bagua, Imaza, Aguaruna Putuim, anex Yamayakat, "campou," $24^{\circ} \mathrm{SW}$ of Putuim, $28.5^{\circ} \mathrm{SW}$ of Yamayakat, 700-750 m, Díaz et al. 7725A (MO, USM); Tayu Mujaji, Comunidad de Wawas, $5^{\circ} 15^{\prime} 25^{\prime \prime} \mathrm{S}, 78^{\circ} 21^{\prime} 41^{\prime \prime} \mathrm{W}, 800 \mathrm{~m}$, Rojas et al. 399 (AAU, MO, NY, USM); Quebrado El Almendro, 5०14'40"S, 78²1'24"W, $430 \mathrm{~m}$, van der Werffet al. 14568 (MO, USM).

Anthurium baguense Croat, sp. nov. Type: Perú. Amazonas: Bagua, Imaza, Aguaruna de Putuim "campou", anex Yamayakat, Monte Alto de Putium, 500 m, 25 Aug. 1994, C. Diaz, S. J. Katip \& P. Atamain 7030 (holotype, MO05081044; isotypes, B, F, K, US, USM).

Fig. 1c.

Planta terrestris, 60-80 cm; internodia brevia, 1.5-2 cm diam.; cataphylla $7-10 \mathrm{~cm}$ longa, persistens in fibras; petioli (18) 3445 (54) cm longi, ca. $5 \mathrm{~mm}$ diam.; laminae ovato-ellipticae, raro lanceolatae, $21-32 \mathrm{~cm}$ longae, $4.3-13.3 \mathrm{~cm}$ latae; nervis primariis lateralis 7-10 utroque; pedunculus (21)27$38(52) \mathrm{cm}$ longus, 3-4 mm diam. in sicco; spatha viridis, lanceolata (1.7)3.5-5.3 cm longa, 3-7 mm lata; spadice viridis, $2-6.3 \mathrm{~cm}$ longus.

Terrestrial, $60-80 \mathrm{~cm}$ tall; internodes short, $1.5-2 \mathrm{~cm}$ diam., cataphylls $7-10 \mathrm{~cm}$ long, soon decomposing to pale brown reticulum of fibers. Petioles (18) 34-45 (54) $\mathrm{cm}$ long, ca. $5 \mathrm{~mm}$ diam., subterete, drying blackened, geniculum $1.5-2.5 \mathrm{~cm}$ long, drying blackened; blades ovate-elliptic or rarely lanceolate, $21-32 \times 4.3-13.3 \mathrm{~cm}$, narrowly acuminate at apex, acute and weakly attenuate at base, dark green and almost matte above, 
drying yellow-green to gray-green, slightly paler and semi-glossy below, drying dark gray-brown; midrib narrowly raised above, convex below, drying somewhat darker than surface; primary lateral veins $7-10$ per side, departing at $45-55^{\circ}$ angle, weakly curved to margin, flat on upper surface, drying weakly raised and less conspicuous than collective veins, convex below; collective veins arising from base, 4- $8 \mathrm{~mm}$ from margin; interprimary veins often present; tertiary veins weakly raised on drying. Inflorescence erect, peduncle (21) 27-38 (52) cm long, drying 3$4 \mathrm{~mm}$ diam., spathe green to reddish green, lanceolate (1.7) $3.5-5.3 \mathrm{~cm} \times 3-7 \mathrm{~mm}$, acuminate at apex, inserted at ca. $45^{\circ}$ angle at base and decurrent for up to $7 \mathrm{~mm}$ on peduncle; spadix $2.0-6.3 \mathrm{~cm}$ long, weakly tapered toward apex, yellowish green to green. Flowers 4-5 visible per spiral, square, 1.7$2.3 \mathrm{~mm}$ long and wide, tepals drying 1-1.2 mm diam., outer margin 2-, or less frequently, 3-4-sided, inner margin concave, style drying button-shaped, $0.5-0.6 \mathrm{~mm}$ diam., $0.2 \mathrm{~mm}$ thick.

Local Aguaruna name: "campounumia eep". Anthurium baguense is known only from Amazonas Department, Bagua Province (hence the name "baguense") at 450-700 m in Premontane wet forest transition to Tropical (P-wf/T) life zones. It is a member of section Porphyrochitonium and is characterized by short internodes, mostly pale-drying, semi-organized cataphyll fibers, narrowly ovate to ovate-lanceolate, blackdrying leaf blades that are semiglossy on the lower surface and have prominent primary lateral veins and a prominently acuminate apex.

Anthurium baguense is similar to $A$. penae Croat, also occuring at the type locality, but $A$. penae differs in having thicker elliptic blades drying yellowish brown, more obscure primary lateral veins, and intact cataphylls that dry darker brown, rather than turning into pale brown fibers as in A. baguense.

Paratypes: PERU. AMAZONAS: Bagua,
Distrito Imaza, Aguaruna de Putuim, 455'S, $78^{\circ} 19^{\prime} \mathrm{W}, 780 \mathrm{~m}, 13$ June 1996, E. Rodríguez et al. 1004 (MO, USM); anex Yamayakat, Monte Alto de Putium, 450 m, Diaz et al. 7008 (COL, F); Communidad zona de Colinas altas, $24^{\circ} \mathrm{SW}$ of Patuim, $660-760 \mathrm{~m}$, Diaz et al. 7179 (MO, QCNE); $7196 A$ (MO).

Anthurium brent-berlinii Croat, sp. nov. Type: Perú. Condorcanqui, Río CenepaKayamas, 213-244 m, 9 Dec. 1972, B. Berlin 518 (holotype, MO-2249065, isotype, USM). Fig. 1d.

Planta epiphytica, internodia brevia, 2$3 \mathrm{~cm}$ diam. in sicco; cataphylla ad $14 \mathrm{~cm}$ longa; persistens in fibris; petioli 70-85 cm longi, $0.5-1.3 \mathrm{~cm}$ diam. in sicco; laminae plerumque cordatae, interdum subhastatae, obpyriformes, $63-67 \mathrm{~cm}$ longae, $48-56 \mathrm{~cm}$ latae; nervis primariis lateralibus 7-10 utroque; pedunculus 39-48 cm longus; spatha pallide viridis, lanceolata vel oblonga, 9.5$19.5 \mathrm{~cm}$ longa, 2-2.8 cm lata; spadice pallide aurantiacus, pendens, $23 \mathrm{~cm}$ longus, $8 \mathrm{~cm}$ diam. in sicco.

Epiphytic; internodes short, drying 2-3 cm diam.; cataphylls up to $14 \mathrm{~cm}$ long, at least 1-ribbed, possibly weakly 2-ribbed, drying reddish brown, lanceolate or oblong, persisting only at upper internodes as a large reticulum of coarse reddish brown fibers (with some longitudinal fibers), eventually deciduous, acute to weakly acuminate at apex. Petioles 70-85 cm long, drying $0.5-1.3 \mathrm{~cm}$ diam., prominently sulcate near base, drying pale grayish brown sometimes tinged with red; geniculum shaped like petiole, concolorous or slightly darker, $1.5-3 \mathrm{~cm}$ long, drying 5-6 mm diam.; blades usually cordate, sometimes weakly subhastate, obpyriform, somewhat abruptly acuminate (acumen 1.5$2 \mathrm{~cm}$ long), 63-67 × 48-56 cm, ca. 1.1-1.3 times longer than wide, drying gray-green above and gray-brown faintly tinged with red below; anterior lobe 48-50 $\times 20-22 \mathrm{~cm}$ at midpoint; posterior lobes $24.5-26.5 \times 14.5-$ $18 \mathrm{~cm}$ at midpoint; sinus parabolic, $15-20 \mathrm{~cm}$ 
deep, 9.5-11 cm wide at midpoint; midrib thicker than broad, concolorous to gray-brown above, narrowly rounded, sometimes drying with a rib, concolorous to slightly paler below; primary lateral veins $7-10$ per side, $2.5-6.5$ $\mathrm{cm}$ apart, departing midrib at a $55^{\circ}-70^{\circ}$ angle, straight or slightly arching towards collective vein, concolorous, somewhat prominent; lesser veins usually faint to obscure; basal veins 6-8 per side, 1 st and 2 nd free to the base, $5^{\text {th }}$ and $6^{\text {th }}$ coalesced to $4.5-5.5 \mathrm{~cm}$, concolorous or slightly paler than surface, raised; posterior rib naked for $5.5-6.5 \mathrm{~cm}$ along sinus; collective veins faint, arising from $1^{\text {st }}$ basal vein, much less prominent than primary lateral veins, 3-11 $\mathrm{mm}$ from margin. Inflorescence with peduncle $39-48 \mathrm{~cm}$ long, drying 3-10 $\mathrm{mm}$ diam., drying grayish to reddish gray; spathe erect to erect-spreading, light green, lanceolate to oblong, 9.5-19.5 $\times$ $2-2.8 \mathrm{~cm}$, acuminate at apex, spadix orange, slightly tapered to apex, slightly stipitate (stipe 4-10 mm long), pendent, $23 \mathrm{~cm}$ long, drying $8 \mathrm{~cm}$ diam. Flowers $2.8-3 \times 2.6-2.8 \mathrm{~mm}, 7$ to 8 visible per spiral; lateral tepals $1.5 \mathrm{~mm}$ wide, 2-sided. Infructescence to $56 \mathrm{~cm}$ long, drying to $1.4 \mathrm{~cm}$ diam.; berries white.

Local Aguaruna name: ináimas.

Anthurium brent-berlinii is known only from northern Perú (Amazonas) at 200-800 $\mathrm{m}$ in Tropical wet forest ( $\mathrm{T}-\mathrm{wf}$ ) and Premontane wet forest transition to Tropical $(\mathrm{P}-\mathrm{wf} / \mathrm{T})$ life zones. It is a member of section Belolonchium and is characterized by large, usually cordate, sometimes obpyriform blades; thick internodes, and large, dark cataphylls. It is most similar to A. kugkumasii Croat, which also has thick internodes, and similarly shaped blades, but $A$. kugkumasii has a smaller, purple spadix, and its blades are less constricted toward the apex and have a more convex margin.

The species is named in honor of Dr. Brent Berlin, anthropologist at the University of Georgia, previously at the University of California, Berkeley, who worked with the Aguaruna and Huambisa Indian tribes of the Amazonas Department, and who collected the type specimen. Berlin's anthropological studies along the Río Marañón enabled numerous new species in many plant families to be collected.

Paratypes: PERU. AMAZONAS: N of Quebrada Huampami, 244-260 m, 13 Dec. 1972, Berlin 522 (MO); Río Santiago, $1 \mathrm{~km}$ behind Caterpiza, E of Quebrada Caterpiza, $200 \mathrm{~m}$, 10 Sep. 1979, Huashikat 503 (MO).

Anthurium ceronii Croat, sp. nov. Type: Ecuador. Napo, $5.7 \mathrm{~km} \mathrm{~W}$ of Tena at Río Tena, $0^{\circ} 01^{\prime} \mathrm{S}, 77^{\circ} 51^{\prime} \mathrm{W}$, ca. $500 \mathrm{~m}$, T. B. Croat 58849 (holotype, MO-3154535; isotypes, AAU, NY, QCA, US).

Planta epiphytica; internodia brevia, usque ad $1 \mathrm{~cm}$ lata; cataphylla $5-8 \mathrm{~cm}$ longa; laminae oblongae-anguste ellipticae, 30 $60 \mathrm{~cm}$ longae, $2-4.5 \mathrm{~cm}$ latae, nervis primaries lateralibus 12-18 utroque; pedunculus 16-25 cm longus, $3 \mathrm{~mm}$ latus, pallide viridis; spatha effusa, luteus-viridis, $6-10 \mathrm{~cm}$ longa, $1-1.5 \mathrm{~cm}$ lata; spadice olivaceus 6-13 cm longa, 4 mm lata ad basum.

Epiphyte; stems pendent, ca. $20 \mathrm{~cm}$ long; internodes short, to $1 \mathrm{~cm}$ diam.; cataphylls 5-8 cm long, green, 1-ribbed and acuminate at apex, persisting more or less intact at upper nodes, drying brown into brittle fibers at lower nodes. Petioles spreading-pendent, sheathed to between $1 / 2$ and $3 / 4$ their length, geniculum upturned, thicker and drying darker than petiole; blades oblong-narrow elliptic, 4-8 times longer than petiole, $30-60 \times 2-4.5 \mathrm{~cm}$, broadest at $2 / 3$ to $3 / 4$ its length from base, moderately coriaceous, narrowly acuminate (acumen 2-4 cm), attenuate at base, both surfaces matte, upper surface dark green, drying gray, lower surface much paler, drying more brown; midrib convexly raised above, convex and much larger below; primary lateral veins $12-18$ per side, departing midrib at $35^{\circ}$ angle, raised slightly more below than above; interprimary veins only slightly less prominent than primary veins; collective veins arising from the base with same prominence as primary lateral veins, $2-5 \mathrm{~mm}$ from margin. Inflorescence spreading, shorter than leaves; 
peduncle $16-25 \mathrm{~cm} \times 3 \mathrm{~mm}$, pale green, quadrangular, the margins winged; spathe spreading, subcoriaceous, yellow-green, linear or narrowly lanceolate, $6-10 \times 1-1.5 \mathrm{~cm}$, broadest near base, inserted at a $60^{\circ}$ angle on petiole, acuminate at apex, acumen inrolled and $5 \mathrm{~mm}$ long, spathe base margins meeting acutely at $50^{\circ}$ angle, stipe $12-20 \mathrm{~mm}$ long in back; spadix olive at anthesis, paler prior to anthesis, long-ellipsoid, bluntly tapered at apex, curved upwards away from spathe, 6 $13 \mathrm{~cm}$ long, $4 \mathrm{~mm}$ diam. at base and at middle, $3 \mathrm{~mm}$ diam. at apex, turning red with age. Flowers slightly rhombic, $2.8 \times 2.2-2.4 \mathrm{~mm}$, 5 in principal spiral, 3 in alternate spiral, the sides nearly straight to slightly sigmoid; tepals matte pre-anthesis, $1.2 \mathrm{~mm}$ wide, inner margins rounded, outer margins 2-sided, pistils raised before stamens emerge, green, stigma slitlike, raised, droplets appearing several days before anthesis, $0.5 \mathrm{~mm}$ long, slightly papillate; stamens emerge in unusual manner, the alternates preceeding laterals by 2 spirals, barely emerging above tepal level, closely circling pistil but not obscuring pistil; anthers white; $0.6-0.7 \times 0.4 \mathrm{~mm}$; thecae $0.2-$ $0.3 \mathrm{~mm}$ wide; pollen white; berries white.

Local Aguaruna name: ináimas, mánkamák.

This species occurs in the Tropical wet forest (T-wf), Premontane wet forest (P-wf), and Premontane rain forest (P-rf) life zones at $400-500 \mathrm{~m}$.

Anthurium ceronii is named for Carlos Cerón who collected this species in the Napo Province of Ecuador.

Paratypes: ECUADOR. NAPO: Est. Biol. Jatun Sacha, $8 \mathrm{~km}$ E of Misahualli, $400 \mathrm{~m}$, $1^{\circ} 04^{\prime} \mathrm{S}, 7^{\circ} 36^{\prime} \mathrm{W}$, Cerón 1475 (MO). PERU. AMAZONAS: Río Cenepa region, Quebrada Aintami, Berlin 351 (US, USM); trail E of Hampami to Shaim, Berlin 1903 (USM).

Anthurium chinimense Croat, sp. nov. Type: Perú. Amazonas: Bagua, Imaza, Aguaruna de Wanás, km 92 Carretera Bagua-Imacita, Cerros Chinim, rocky borders of creek, 650750 m, 27 Aug. 1997, C. Díaz, A. Peña, L. Tsamajain \& M. Roca 7987 (holotype, MO-
04922228; isotypes, K, US, USM). Fig. 2a.

Planta terrestris; internodia ca. $1.5 \mathrm{~cm}$ longa, $1.3 \mathrm{~cm}$ diam. in sicco; cataphylla $5.5-$ $9 \mathrm{~cm}$ longa; petioli $20.6-34.5 \mathrm{~cm}$ longi, 3-4 $\mathrm{mm}$ diam. in sicco; laminae ovatae, 26-31.3 $\mathrm{cm}$ longae, $10.3-12.4 \mathrm{~cm}$ latae; nervis primariis lateralibus $8-10$ utroque; pedunculus $25-35.5 \mathrm{~cm}$ longus; spatha viridis, ca. $7 \mathrm{~mm}$ longa, 1-1.2 cm lata; spadice viridis, 7.5-8.5 cm longus, 3-5 mm diam.

Terrestrial; internodes ca. $1.5 \mathrm{~cm}$ long, drying ca. $1.3 \mathrm{~cm}$ diam.; cataphylls $5.5-9 \mathrm{~cm}$ long, finely ridged, oblong to lanceolate, persisting at upper internodes, remaining intact, then weathering to a reticulum of coarse tan fibers. Petioles 20.6-34.5 cm long, drying 3-4 mm diam., sometimes grooved near base, grayish brown to medium brown, finely ridged; geniculum shaped like petiole; slightly darkened, 1-2 cm long, drying 3-4 mm diam.; blades ovate, long-acuminate at apex (acumen $2-2.8 \mathrm{~cm}$ long), attenuate at base, $26-31.3 \mathrm{~cm}$ long (averaging $29 \mathrm{~cm}$ ), $10.3-12.4 \mathrm{~cm}$ wide (averaging $11.5 \mathrm{~cm}$ ), 2.4-2.5 times longer than wide, 0.9-1.3 times longer than petiole, drying olive to brownish green, weakly glossy, sometimes matte above, eglandular, slightly paler, weakly glossy to semi-glossy, densely glandular-punctate below; midrib 1-2 $\mathrm{mm}$ wide, concolorous to darker, convex to narrowly convex above; brown, narrowly rounded below; primary lateral veins $8-10$ per side, $1-3 \mathrm{~cm}$ apart, departing midrib at a $55-60^{\circ}$ angle (occasionally arising at an acute angle and then spreading to $55-60^{\circ}$ angle), slightly curved to the collective vein, concolorous and almost obscure above, concolorous to brown and somewhat prominent below; collective veins usually 2 , both arising at an acute angle from near base, the $2^{\text {nd }}$ collective vein beginning to spread toward margin about 1$1.5 \mathrm{~cm}$ before the $1^{\text {st }}$, both more prominent than primary lateral veins, the $1^{\text {st }}$ collective vein $0.5-2.5 \mathrm{~cm}$ from the margin, the $2^{\text {nd }} 5-1$ $\mathrm{mm}$ from margin near base, less than $1 \mathrm{~mm}$ from margin near middle and apex of blade. Inflorescences with peduncle $25-35.5 \mathrm{~cm}$ long, drying 2-3 $\mathrm{mm}$ diam., drying grayish 
brown or darkened; spathe reflexedspreading, green, linear, ca. $7 \mathrm{~mm} \times 1-1.2 \mathrm{~cm}$; spadix green, more or less erect, $7.5-8.5 \mathrm{~cm}$ $\times 3-5 \mathrm{~mm}$. Flowers $2-2.5 \times 1.9-2 \mathrm{~mm}, 5$ visible per spiral; lateral tepals $1.2-1.4 \mathrm{~mm}$ wide, 2-sided.

Anthurium chinimense is known only to northern Perú (Amazonas, Bagua) at 430-650 $\mathrm{m}$ in Premontane wet forest (P-wf) and Tropical moist forest (T-mf) life zones. This species is a member of Anthurium section Porphyrochitonium and is characterized by ovate blades, dark olive-green to green-brown drying blades, and two prominent collective veins. It is similar to $A$. weberbauerii Engl. in that both species have somewhat ovate blades with two prominent collective veins. However, $A$. weberbauerii has blades that dry a more yellow-brown color and are only acute or even rounded at the apex.

The species is named for the type locality, Cerros Chinim, in the Imaza District, Bagua Province, Amazonas Department, Peru. Paratypes. PERU. AMAZONAS: Bagua, Quebrado El Almendro, 5¹4'40"S, $78^{\circ} 21^{\prime} 24^{\prime \prime} \mathrm{W}, 430 \mathrm{~m}$, van der Werff et al. 14548 (B, NY).

Anthurium diazii Croat, sp. nov. Type: Perú. Amazonas: Bagua, Imaza, Aguaruna de Wanás (km 92 Carretera Bagua-Imacita), Chinim hills, 650-750 m, 27 Aug. 1996, C. Díaz, A. Peña, L. Tsamajain \& M. Roca $7987 A$ (holotype, MO-04922229). Fig. 2b.

Planta terrestris; internodia brevia, $1 \mathrm{~cm}$ diam. in sicco; cataphyllae $12.5 \mathrm{~cm}$ longae; petioli 22-37.5 cm longi, 3-5 mm diam. in sicco; laminae $31-33 \mathrm{~cm}$ longae, $6.3-7 \mathrm{~cm}$ latae, nervis primariis lateralibus (11-)1315 utroque; pedunculus $37 \mathrm{~cm}$ longus, ca. 2 mm diam. in sicco; spatha viridis, $6.5 \mathrm{~cm}$ longa, $5 \mathrm{~mm}$ lata in sicco; spadice viridis, $11 \mathrm{~cm}$ longus, $6 \mathrm{~mm}$ lata in sicco.

Terrestrial; internodes short, drying ca. $1 \mathrm{~cm}$ diam.; cataphylls $12.5 \mathrm{~cm}$ long, drying pale tan, weathering to longitudinal fibers near apex, to a reticulum of finer fibers near base, at upper nodes, eventually deciduous. Petioles
22-37.5 cm long, drying 3-5 mm diam., medium brown-tinged with gray; blades $+/-$ elliptic, narrowly acuminate at apex (acumen $2-2.6 \mathrm{~cm}$ long), slightly attenuate at base, $31-$ $33 \mathrm{~cm}$ long, $6.3-7 \mathrm{~cm}$ wide, 4.7-4.9 times longer than wide, drying matte, greenish brown above, weakly to semiglossy, brown faintly tinged with yellow and dark glandular-punctate below; midrib slightly raised, concolorous above, narrowly rounded, concolorous below; primary lateral veins (11-)13-15 per side, scarcely more prominent than interprimary veins; collective veins arising from near base, prominent above and below, 3-8 $\mathrm{mm}$ from margin. Inflorescence with peduncle $37 \mathrm{~cm}$ long, drying ca. $2 \mathrm{~mm}$ diam.; spathe spreading, green, oblong to oblong-elliptic, $6.5 \mathrm{~cm}$ long, drying $5 \mathrm{~mm}$ wide at widest part near base, furled; spadix (post-anthesis) green, tapered near apex, 11 $\mathrm{cm}$ long, drying $6 \mathrm{~mm}$ wide. Flowers 2.8-3 $\mathrm{mm}$ long, 2.2-3.2 $\mathrm{mm}$ wide, (2-) 3-4 visible per spiral; lateral tepals $1.2-1.5 \mathrm{~mm}$ wide, outer margin 2-sided, inner margins not straight, concave at center with its lateral edges forming an acute angle with the sides of the tepal.

Anthurium diazii is endemic to the type locality in northern Perú (Bagua, Imaza) at 650-750 $\mathrm{m}$ in Tropical wet forest (T-wf) or Premontane rain forest (P-rf) life zones. This species is characterized by its darkened, elliptic to oblong-elliptic blades that are almost five times longer than wide. It is most closely related to $A$. lingulare, which also has blades somewhat longer than wide and a long spadix. However, A. lingulare is epiphytic, has strap-shaped blades 9 to 10 times longer than wide, and a maroon spadix.

The species is named in honor of Camilo Diaz, a prominent Peruvian collector and part of the group of botanists who collected the type specimen.

Anthurium galileanum Croat, sp. nov. Type: Perú. Amazonas: Río Santiago, vic. of Galilea, 180 m, 20 Aug. 1979, V. Huashikat 79 (holotype, MO-2773365). Fig. 2c. 

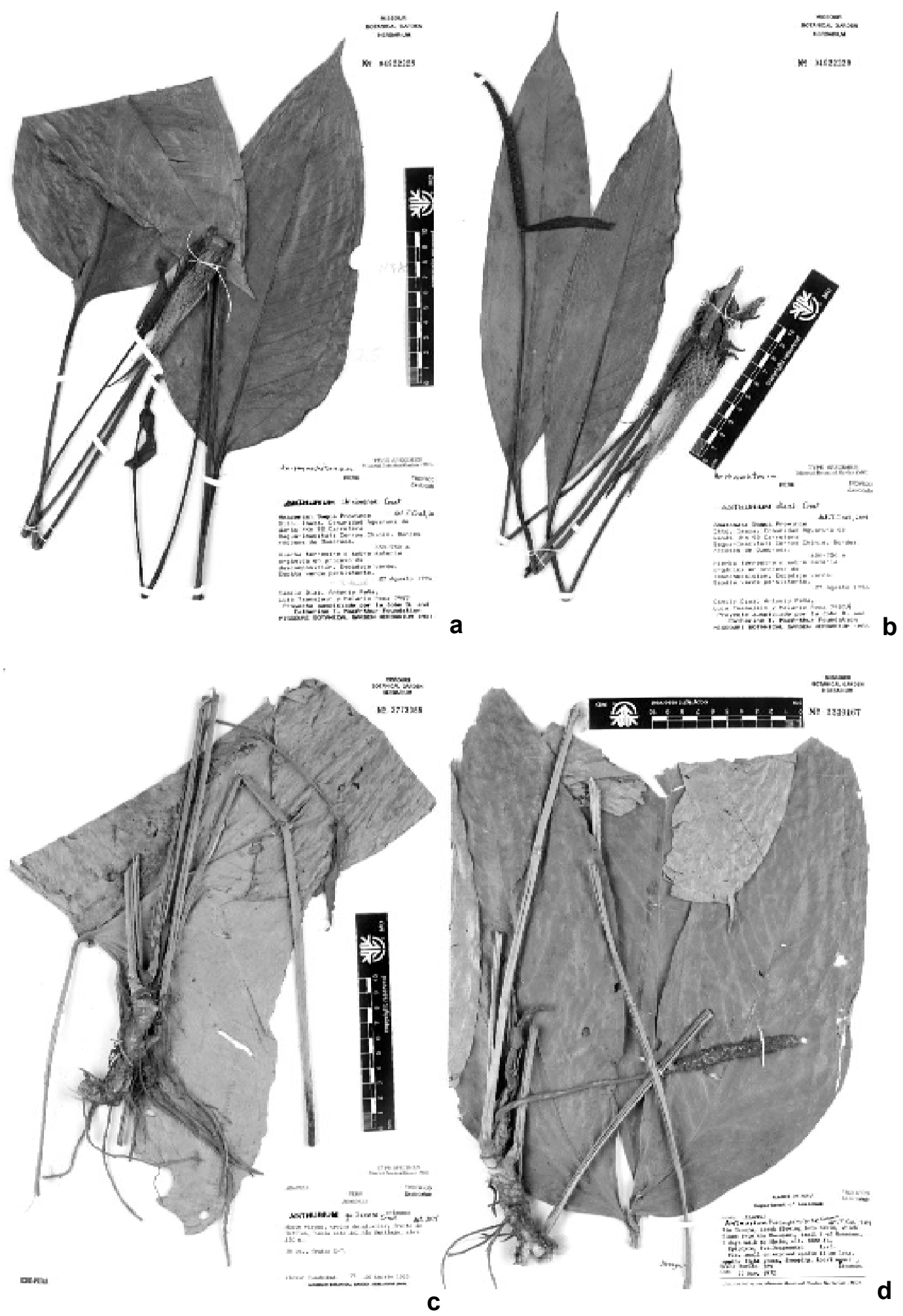

Figure 2 - a. Anthurium chinimense Croat. Type specimen. (Díaz et al. 7987); b. Anthurium diazii Croat. Type specimen. (Díaz et al. 7987A); c. Anthurium galileanum Croat. Type specimen. (Huashikat 79); d. Anthurium huampamiense Croat. Type specimen. (Berlin 389) 
Planta terrestris; internodia brevia, 1.2 $2 \mathrm{~cm}$ diam.; cataphylla persistens intacta; petioli ca. $43 \mathrm{~cm}$ longi; laminae triangularishastatae, $43 \mathrm{~cm}$ longae, $40 \mathrm{~cm}$ latae; lobulae posterioris $20.5 \mathrm{~cm}$ longae, $11 \mathrm{~cm}$ latae; pedunculus $28 \mathrm{~cm}$ longi; spatha $7.5 \mathrm{~cm}$ longa, $0.9 \mathrm{~cm}$ lata; spadice ca. $6 \mathrm{~cm}$ longus, 5 mm diam. in sicco.

Terrestrial; internodes short, drying $1.2-2 \mathrm{~cm}$ diam., grayish brown; cataphylls ca. $5.5 \mathrm{~cm}$ long, drying pale reddish gray or reddish brown, oblong or lanceolate, persisting intact at upper internodes only, sometimes starting to weather to pale longitudinal fibers, then quickly deciduous. Petioles ca. $43 \mathrm{~cm}$ long, drying 4-6 $\mathrm{mm}$ diam., sulcate at least near base, drying smooth, reddish gray; geniculum red, $1.5 \mathrm{~cm}$ long, drying $4 \mathrm{~mm}$ diam., minutely ridged and warty on drying; blades triangular-hastate, bluntly acute and shortly acuminate at apex, prominently lobed at base, $43 \times 40 \mathrm{~cm}$, drying gray, tinged with green, semi-glossy above, drying grayish green, matte to weakly glossy below; anterior lobe $38.5 \mathrm{~cm}$ long, $12 \mathrm{~cm}$ wide at midpoint, $+/$ - straight at margins; posterior lobe $20.5 \times 11 \mathrm{~cm}$, sinus broadly parabolic, $4.5 \mathrm{~cm}$ deep; midrib narrowly rounded with an acute medial rib, +/- concolorous below; primary lateral veins ca. 8 per side, $1.5-3.5$ $\mathrm{cm}$ apart, departing midrib at a ca. $50^{\circ}$ angle, essentially straight to a collective vein, bluntly and narrowly raised above, concolorous to slightly paler and bluntly acute below; basal veins ca. 4 per side, $1^{\text {st }}$ almost free to base,

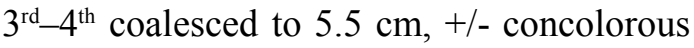
below, weakly raised; posterior rib naked 5 $\mathrm{cm}$ long along the sinus; collective veins arising from one of the lower basal veins, about equally as prominent as primary lateral veins, 7-10 $\mathrm{mm}$ from margin. Inflorescence with peduncle $28 \mathrm{~cm}$ long, drying 1-2 mm diam., pale reddish brown tinged with gray; spathe erect, drying reddish brown tinged with gray, lanceolate, $7.5 \times 0.9 \mathrm{~cm}$, gradually acuminate at apex; spadix drying reddish brown, somewhat tapered, erect, somewhat curved, ca. $6 \mathrm{~cm}$ long, drying $5 \mathrm{~mm}$ diam.
Flowers $1.6-1.9 \times 1.8-2.1 \mathrm{~mm}, 4-5$ visible per spiral; tepals minutely granular and frosted white; lateral tepals $0.8-1.1 \mathrm{~mm}$ wide, inner margins broadly rounded, outer margins 3sided.

Local Aguaruna name: shinumas.

Anthurium galileanum is known only from the type locality in northern Perú at 180 $\mathrm{m}$ in the Tropical moist forest (T-mf) life zone. It is a member of section Cardiolonchium and is characterized by triangular-hastate blades drying pale gray-green with pale or concolorous venation. It is similar to $A$. breviscapum in drying color of the blades and spadix, but $A$. breviscapum is a hemiepiphytic climber, with cordate blades with convex margins, and internodes typically longer than broad with a smooth, moderately pale, finely striate epidermis. In contrast, A. galileanum has short internodes and triangular-hastate blades.

The species is named for the type locality, the village of Galilea along the Río Santiago.

Anthurium huampamiense Croat, sp. nov. Perú. Amazonas: creek flowing into Nahim, flowing into the Huampami, trail E of Huampami, 1-day walk to Shaim, 550 m, 27 Nov. 1972, B. Berlin 389 (isotype, MO2249167). Fig. $2 d$.

Planta epiphytica; internodia brevia, 1.5 cm diam.; cataphylla $10.5 \mathrm{~cm}$ longa; petioli 60-69 cm longi, 4-6 mm diam. in sicco; laminae trisectae, $35-43.5 \mathrm{~cm}$ longae, griseoviridis in sicco; lobulae mediae obovatae vel late ellipticae, 35-43.5 cm longae, 18-19.5 cm latae; nervibus primariis lateralibus 7-9 utroque; pedunculus $14.5 \mathrm{~cm}$ long, $4 \mathrm{~mm}$ diam. in sicco; spatha lanceolata, ca. $10 \mathrm{~cm}$ longa, $2.4 \mathrm{~cm}$ lata; spadice cylindroideus, 6$12 \mathrm{~cm}$ longus, 5-8 mm diam. in sicco.

Epiphytic; internodes short, smooth, less than $1 \mathrm{~cm}$ long, drying ca. $1.5 \mathrm{~cm}$ diam., tan; cataphylls $10.5 \mathrm{~cm}$ long, drying light red, $+/$-linear, persisting intact at upper internodes, then quickly deciduous. Petioles $60-69 \mathrm{~cm}$ long, drying 4-6 mm diam., drying light 
reddish gray; geniculum slightly darker than petiole, ca. $1 \mathrm{~cm}$ long, drying ca. $5 \mathrm{~mm}$ diam., wrinkled; blades trisect, broader than long, drying gray-green to light red-brown and weakly glossy to semi-glossy above, yellowish green to pale orange-brown and semi-glossy below; segments entire, median segment obovate to broadly elliptic, 35-43.5 $\times 18-19.5 \mathrm{~cm}$, abruptly acuminate (acumen ca. $2 \mathrm{~cm}$ long), acute to attenuate at base; midrib narrowly convex, thicker than broad, drying ca. $1 \mathrm{~mm}$ diam., surface densely marked with minute, brown irregular lines on magnification, light brown to light red brown above, light brown below; primary lateral veins 7-9 pairs, $2.5-4 \mathrm{~cm}$ apart, departing midrib at a $40-50^{\circ}$ angle; interprimary veins almost as prominent as primary veins; collective veins arising from near base, almost as prominent as primary lateral veins, $0.6-1.2$ $\mathrm{cm}$ from margin; lateral segments somewhat ovate to broadly elliptic, markedly inequilateral (one side up to $1.5 \mathrm{~cm}$ longer than the other), 30-37 × 13-14 cm, directed upward and outward, rounded at apex; midrib slightly less prominent than on median segment, brown to almost concolorous above, not extending to apex of segment but merging with collective vein on outer side of the segment; 1-2 prominent veins near base on one side of midrib only, then 5-7 less conspicuous veins per side, $2-5 \mathrm{~cm}$ apart, departing midrib at a $35-45^{\circ}$ angle, slightly curved to a collective vein, concolorous to slightly paler above, the less conspicuous veins sometimes more raised and prominent on outer side of the midrib than the inner side; collective veins 1 or 2 arising from prominent primary lateral veins on outer side of midrib ( 2 collective veins only on the side of midrib with 2 prominent primary lateral veins, still only 1 collective vein on the other side), arising from near base on the other side, as prominent or slightly less prominent than primary lateral veins, $1^{\text {st }}$ collective vein 0.5 $1.2 \mathrm{~cm}$ from margin, $2^{\text {nd }}$ collective vein $2-4$ $\mathrm{cm}$ from margin. Inflorescence with peduncle $14.5 \mathrm{~cm}$ long, drying $4 \mathrm{~mm}$ diam., medium reddish brown; spathe erect-spreading, light green, lanceolate, ca. $10 \mathrm{~cm}$ long, $2.4 \mathrm{~cm}$ wide, gradually acuminate at apex (acumen curled, ca. $8 \mathrm{~mm}$ long); spadix (post anthesis) cylindroid, erect, 6-12 cm long, drying 5-8 $\mathrm{mm}$ diam. Flowers $1.9-2 \times 2-2.1 \mathrm{~mm}, 7-8$ visible per spiral; lateral tepals $1-1.2 \mathrm{~mm}$ diam., 2-sided.

Anthurium huampamiense is known only from the type locality in Perú at $550 \mathrm{~m}$ in Premontane wet forest transitioning to Tropical $(\mathrm{P}-\mathrm{wf} / \mathrm{T})$ life zone. It is characterized by broad, trisect blades with lateral segments and midribs that do not reach all the way to the apex of the segment. It is closely related to $A$. triphyllum in blade shape, size and venation, but $A$. triphyllum has blades that dry more brown and lack the minute, irregular lines on the surface.

This species is named for the village Huampami, near the type collection locality.

Anthurium huashikatii Croat, sp. nov. Type: Perú. Amazonas: Bagua, Río Santiago valley, ca. $65 \mathrm{~km} \mathrm{~N}$ of Pinglo, Quebrada Caterpiza, 2-3 km behind Caterpiza, $200 \mathrm{~m}, 13 \mathrm{Feb}$. 1980, V. Huashikat 2089 (holotype, MO2828544). Fig. 3a.

Planta epiphytica; internodia brevia, $1-$ $1.3 \mathrm{~cm}$ diam. in sicco; cataphyllae ca. $6.5 \mathrm{~cm}$ longae; petioli $18.5-46.5 \mathrm{~cm}$ longi, 2-4 $\mathrm{mm}$ diam. in sicco; lamina anguste oblanceolatae, $37-38 \mathrm{~cm}$ longae, $6.2-7 \mathrm{~cm}$ latae; nervis primariis lateralibus 12-13 utroque; pedunculus $30 \mathrm{~cm}$ longus; spatha reflexa, ca. $3 \mathrm{~mm}$ lata; spadice stipitatus $1.5-1.8 \mathrm{~cm}, \mathrm{ca}$. $10 \mathrm{~cm}$ longus.

Epiphytic, internodes short, drying 1$1.3 \mathrm{~cm}$ diam.; cataphylls ca. $6.5 \mathrm{~cm}$ long, pale tan, weathering to coarse longitudinal fibers, persistant at upper nodes, then eventually deciduous. Petioles 18.5-46.5 cm long, drying 2-4 mm diam., yellowish brown; blades narrowly oblanceolate, somewhat narrowly acuminate at apex (acumen $3-3.5 \mathrm{~cm}$ long), $37-38 \times 6.2-7 \mathrm{~cm}$, greenish brown above, eglandular, paler below with dark punctations; midrib slightly raised, concolorous above, 
rounded, concolorous below; primary lateral veins $12-13$ per side, slightly more prominent than interprimary veins, arising at a $35-40^{\circ}$ angle from the midrib; collective veins arising from near base, more prominent than primary veins, $3-5 \mathrm{~mm}$ from margin. Inflorescences with peduncle $30 \mathrm{~cm}$ long; spathe reflexed, about $3 \mathrm{~mm}$ wide where it attaches to base, otherwise lost; spadix slightly tapered, prominently stipitate (stipe $1.5-1.8 \mathrm{~cm}$ long), ca. $10 \mathrm{~cm}$ long. Flowers 1.9 $2 \times 1.1-1.5 \mathrm{~mm}, 3-4$ visible per spiral; lateral tepals $0.9-1.1 \mathrm{~mm}$ wide, outer margins twosided. Infructescence $12 \mathrm{~cm}$ long, drying $6 \mathrm{~mm}$ wide, setting fruit in lower 3/4 only.

Local Aguaruna name: yakiya sugkip.

Anthurium huashikatii is endemic to the type locality in northern Perú (Santiago river valley) at $200 \mathrm{~m}$ in Tropical moist forest (T$\mathrm{mf}$ ) and Premontane wet forest (P-wf) life zones. This species is a member of section Porphyrochitonium and is characterized by a very long stipe and narrowly oblanceolate blades. It is similar to $A$. tunquii, but that species has a much shorter stipe and more oblong-elliptic blades.

The species is named in honor of Victor Huashikat, an indigenous plant collector who assisted Brent Berlin with anthropological studies among the Aguaruna and Huambisa Indians in the State of Amazonas, Perú. Huashikat collected many excellent specimens and discovered many new species.

Anthurium kayapii Croat, sp. nov. Type: Perú. Loreto: Alto Amazonas, Andoas, left margin of Río Pastaza, Campameto OXI, $2^{\circ} 55^{\prime} \mathrm{S}, 7^{\circ} 25^{\prime} \mathrm{W}, 4$ June 1981, R. Vasquez \& N. Jaramillo 1880 (holotype, MO-3097485; isotypes, K, USM). Fig. 3b.

Planta epiphytica; internodia brevia, 1 $1.5 \mathrm{~cm}$ diam; cataphyllae $7-10.3 \mathrm{~cm}$ longae; petioli $19 \mathrm{~cm}$ longi, 3-4 mm diam. in sicco; laminae oblanceolatae, $36.8-49 \mathrm{~cm}$ longae, $5.1-8 \mathrm{~cm}$ latae; pedunculus 23-44 cm longus, 2-3 mm diam. in sicco, atrobrunneolus; spatha 7.5-10 cm longa, 4-8 mm lata; spadice viridis vel subroseus, $9.5-18.5 \mathrm{~cm}$ longus, 2
$4 \mathrm{~mm}$ diam.

Epiphytic; internodes short, $1-1.5 \mathrm{~cm}$ diam.; cataphylls $7-10.3 \mathrm{~cm}$ long, persisting as fine fibers in a semi-intact network or moderately disorganized. Petioles subterete, $19 \mathrm{~cm}$ long, drying 3-4 mm diam.; blades narrowly oblanceolate, $36.8-49 \times 5.1-8 \mathrm{~cm}$, 4.3-7.8 times longer than wide, $1.8-3.1$ times longer than petioles, gradually longacuminate at apex, narrowly acute at base, subcoriaceous, drying weakly glossy to semiglossy, dark yellow-brown to gray-brown above, slightly paler and yellow-brown below, margin curled under; midrib drying convex to $+/$-acute and finely and irregularly several-ridged and concolorous above, narrowly raised and finely many-ridged, slightly darker than surface below; primary lateral veins $9-12$ per side, arising at $25-40^{\circ}$ angle, moderately more conspicuous than the interprimary veins and about as prominent as the collective veins; collective veins arising from the base and mostly $2-5 \mathrm{~mm}$ from the margins; tertiary veins moderately prominent on the lower surface. Inflorescence erect, about as long as or shorter than the leaves; peduncle $23-44 \mathrm{~cm}$ long; drying $2-3 \mathrm{~mm}$ in diam., dark yellow-brown; spathe $7.5-10 \mathrm{~cm}$ $\times 4-8 \mathrm{~mm}$, oblong-ligulate, green to white, narrowly acuminate, (soon falling on most herbarium material); spadix green to pink, narrowly linear-tapered, $9.5-18.5 \mathrm{~cm} \times 2-4$ $\mathrm{mm}$, drying dark brown. Flowers $1.5-1.6 \mathrm{~mm}$ long and wide, 5-6 visible per spiral, sides straight parallel to the spirals, smoothly sigmoid perpendicular to the spirals; lateral tepals $0.8 \mathrm{~mm}$ wide, broadly rounded on inner margin, 2-sided on outer margin; berries lavender (B\&K purple 2.5/6), +/- globose, $3-$ $4 \mathrm{~mm}$ diam., drying dark yellow-brown with subglobular, white cellular inclusions in pericarp; seeds 3 or more per berry, ca. 1.4 $\mathrm{mm}$ long.

Local Aguaruna name: eep.

Anthurium kayapii is apparently endemic to Perú in Amazonas and Loreto Departments at 210-650 $\mathrm{m}$ in Premontane wet forest transition to Tropical (P-wf/T) and Tro- 

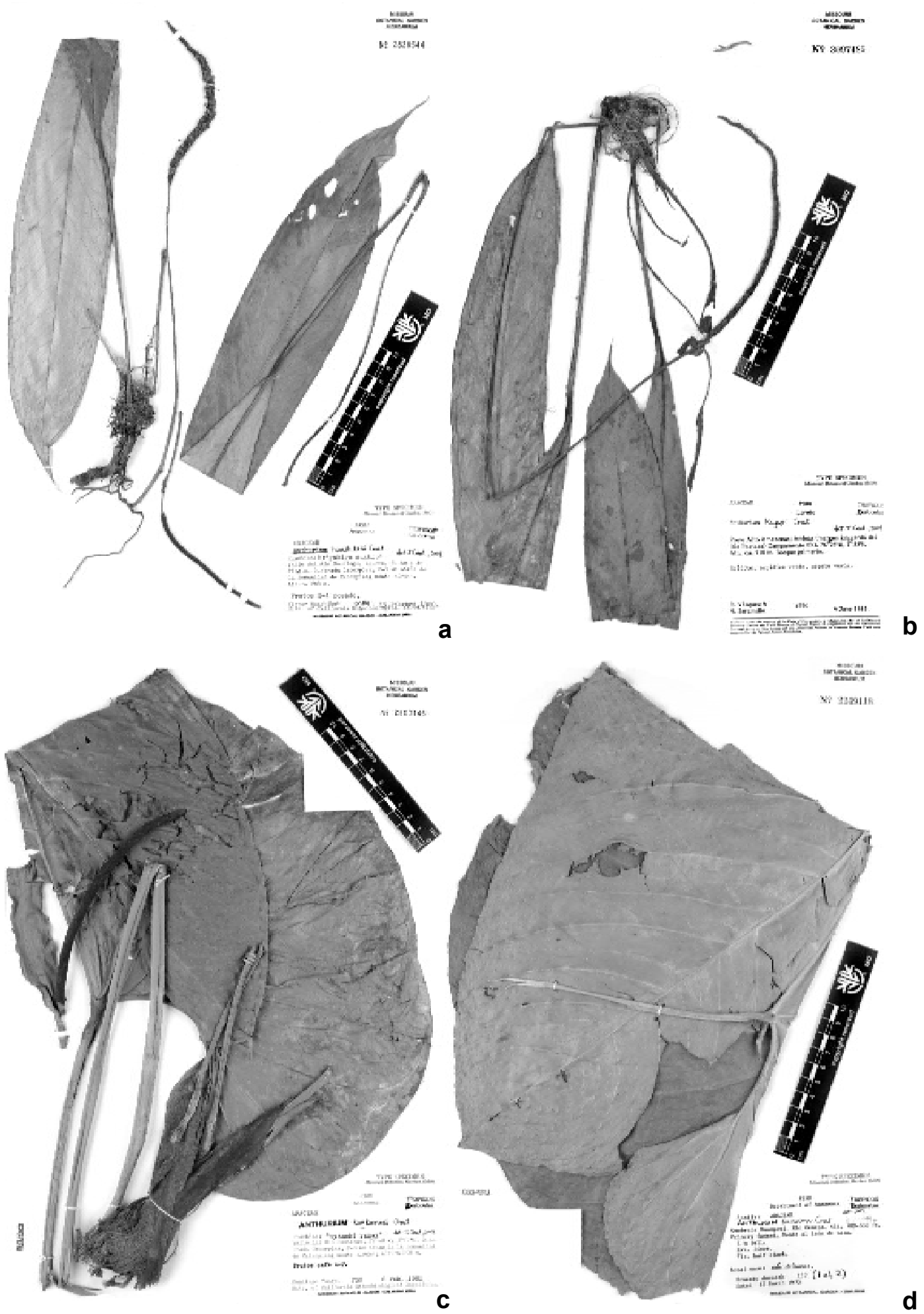

Figure 3 - a. Anthurium huashikatii Croat. Type specimen. (Huashikat 2089); b. Anthurium kayapii Croat. Type specimen. (Vásquez \& Jaramillo 1880); c. Anthurium kugkumasii Croat. Type specimen. (Tunqui 730); d. Anthurium kusuense Croat. Type specimen. (Ancuash 137) 
pical moist forest (T-mf) life zones. It is a member of section Porphyrochitonium and is recognized by short internodes, persistent pale cataphyll fibers, moderately long petioles, narrowly oblanceolate brownish yellowdrying blades with widely spaced primary lateral veins and by a long, slightly tapered spadix and small, globose, lavender berries.

Anthurium kayapii is similar to $A$. apanui, but differs in having narrower, more oblanceolate, darker yellow-brown leaf blades (5.5-7.8 times longer than wide versus 4.6-4.7 times longer than wide in A. apanui) with 8-11 primary lateral veins (versus 5 for A. apanui), and longer cataphylls $(8-11 \mathrm{~cm}$ long versus less than $6 \mathrm{~cm}$ for $A$. apanui).

The species is named in honor of Rubio Kayap, Peruvian botanist collecting with Brent Berlin, who made the first collection of the species in January, 1973 at Quebrada Chigkishinuk in Amazonas, Perú.

Paratypes: PERU. AMAZONAS: Chigkishinuk, monte al lado de Chigkishinuk, 31 Jan. 1973, R. Kayap 285 (MO); LORETO: Alto Amazonas, Manseriche, Pongo de

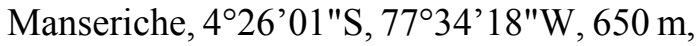
25 Nov. 1997, R. Rojas et al. 647 (MO).

Anthurium kugkumasii Croat, sp. nov. Type: Perú. Amazonas: Huambisa, Río Santiago valley, $2-3 \mathrm{~km}$ behind Caterpiza, $77^{\circ} 40^{\prime} \mathrm{W}$, 350'S, 200 m, 6 Feb. 1980, S. Tunqui 730 (holotype, MO-2900146; isotype, USM).

Fig. 3c.

Planta terrestris; internodia brevia, 3$3.5 \mathrm{~cm}$ diam. in sicco; cataphylla $9.5-15 \mathrm{~cm}$ longa; petioli 71-74 cm longus, 5-7 mm diam. in sicco; laminae late cordatae, $59-61.5 \mathrm{~cm}$ longae, 39-43 cm latae; lobulae posterior, 20-22 cm longae, $14-15 \mathrm{~cm}$ latae; nervis primariis lateralibus 6-8 utroque; pedunculus $28-31 \mathrm{~cm}$ longus, ca. $5 \mathrm{~mm}$ diam. in sicco; spatha viridis, lanceolata, 10.5-15.5(-19) cm longa, 2-2.4(-5.3) cm lata; spadice atropurpureus, $9.5-16 \mathrm{~cm}$ longus, $6-7 \mathrm{~mm}$ diam. in sicco.

Terrestrial; internodes shorter than broad, drying 3-3.5 cm diam.; cataphylls 9.5-
$15 \mathrm{~cm}$ long, unribbed, drying dark red-brown, persisting at upper internodes as dense, coarse, dark, mostly longitudinal fibers. Petioles 71$74 \mathrm{~cm}$ long, drying 5-7 mm diam., sulcate at least near base, drying gray, sometimes pale grayish green near base; geniculum 1.8-2.5 x $5-9 \mathrm{~cm}$, concolorous or sometimes brown-red, sometimes minutely ridged or wrinkled; blades cordate with margins broadly convex; somewhat narrowly acuminate at apex (acumen 1.3-2.5 cm long), 59-61.5 × 39-43 $\mathrm{cm}, 1.3-1.5$ times longer than broad, ca. 0.8 times the length of the petiole, drying graygreen above, reddish gray below; anterior lobe $42.5-45 \times 19-23 \mathrm{~cm}$ at midpoint; posterior lobe $20-22 \times 14-15 \mathrm{~cm}$; sinus broadly spathulate, $15-16 \mathrm{~cm}$ deep; midrib narrowly rounded, drying 1-2 $\mathrm{mm}$ wide, slightly paler above, thicker than broad, sometimes acute, concolorous to slightly darker below; primary lateral veins $6-8$ per side, $2-5 \mathrm{~cm}$ apart, departing midrib at a $\left(40^{\circ}-\right) 50^{\circ}-60^{\circ}$ angle, +/- straight or slightly arching to a collective vein, somewhat prominent above, prominent below; basal veins 7-9 per side, $1^{\text {st }}$ pair free or almost free to base, $6^{\text {th }}$ and $7^{\text {th }}$ coalesced to $5.5-6.5 \mathrm{~cm}$; posterior rib naked $5.5-7.5 \mathrm{~cm}$ along sinus; collective veins sometimes arising from one of the lower basal veins, sometimes from about the middle of the blade, somewhat less prominent than primary lateral veins, 3-7 $\mathrm{mm}$ from margin. Inflorescence with peduncle $28-31 \mathrm{~cm}$ long, drying ca. $5 \mathrm{~mm}$ diam., drying grayish red or yellow-brown; spathe erect, green, lanceolate, $10.5-15.5(-19) \times 2-2.4(-5.3) \mathrm{cm}$; spadix dark purple, curved away from spathe, slightly stipitate (stipe 5-6 mm long), 9.5-16 cm long, drying 6-7 mm diam. Flowers 1.7-2 × 1.8 $\mathrm{mm}, 6-7(-8)$ visible per spiral; lateral tepals $1.2-1.5 \mathrm{~cm}$ wide, 2 -sided.

Local Aguaruna name: uyanchi yakay.

Anthurium kugkumasii occurs in Perú (Amazonas) at 180-200 $\mathrm{m}$ in Premontane wet forest transition to Tropical (P-wf/T) life zone. It is a member of section Belolonchium and is characterized by a dark purple spadix, large cordate blades with broadly convex margins, 
and a spathulate sinus. Anthurium kugkumasii is similar to A. brent-berlinii, but that species has a larger, orange spadix and blades with a constricted anterior lobe.

The species is named in honor of Rubel Kugkumas, an indigenous Aguaruna Indian who was an assistant plant collector for the Flora of Río Cenepa project with Rodolfo Vasquez in 1995-1997. Rubel lives in the Río Cenepa area.

Paratypes: PERU. AMAZONAS: Bagua, Yamayakat, Kusu-Chapi, Imaza, Río Marañon, area permanente $500 \times 500 \mathrm{~m}$, parcel 'E”, 4'55'S, 78 ${ }^{\circ} 19^{\prime} \mathrm{W}, 550 \mathrm{~m}$, Feb. 1995, Vasquez et al. 19769 (MO). HUANUCO: ca. 46 km NNE of HuánucoTingo María, tunnel at Carpish pass, $2600 \mathrm{~m}$, 14 July 1981, Dillon 2589 (F).

Anthurium kusuense Croat, sp. nov. Type: Peru. Amazonas: Huampami, Río Cenepa, 213-244 m, 12 Mar. 1973, E. Ancuash 137 (holotype, MO-2249118, MO-2239373).

Figs. 3d, 4a.

Planta terrestris vel epiphytica; internodia brevia, $1.5-2 \mathrm{~cm}$ longa, $2.7-3.5 \mathrm{~cm}$ lata; cataphylla (6.5) 8.5-9.2(10) cm longa; petioli $78.6-92.5(111) \mathrm{cm}$ long, $6-11 \mathrm{~mm}$ diam.; laminae ovatae vel late ovatae, profunde cordatae, 63-65.5 cm longae, 38$58 \mathrm{~cm}$ latae; nervis primariis lateralibus 7-8 utroque; pedunculus (21.8)28-43.2 cm longus, 2-8 $\mathrm{mm}$ diam.; spatha pallida virido vel viridis, (7) $9.5-12.7 \mathrm{~cm}$ longa, $1.9-2.6 \mathrm{~cm}$ lata; spadice $5.6-9.4 \mathrm{~cm}$ longus, $4-8 \mathrm{~mm}$ diam., albus vel pallide viridis.

Terrestrial or epiphytic, to $1 \mathrm{~m}$, stems erect, $16 \times 2.7-3.5 \mathrm{~cm}$, drying brownish gray, woody; leaf scars conspicuous, hippocrepiform, 1-2 cm deep, 1.4-1.9 cm wide; internodes short, $1.5-2 \times 2.7-3.5 \mathrm{~cm}$, roots adventitious, emerging from nodes of the erect stem, drying brownish gray, scurfy, to $16 \mathrm{~cm}$ long, roots $2.5-3 \mathrm{~mm}$ diam.; cataphylls ribbed, (6.5) 8.5-9.2 (10) cm long, lanceolate, acute at apex, subcoriaceous, drying grayish brown, persisting semi-intact, dilacerating as coarse, yellow-brown linear fibers with the apex occasionally remaining intact. Petioles 78.6-92.5(111) cm × 6-11 mm, erect, sulcate, purple when fresh, drying gray-green, weakly striate to speckled; blades subcoriaceous, ovate to widely ovate, acute at apex, deeply cordate at base, $63-65.5 \times 38-58 \mathrm{~cm}$, broadest at point of petiole attachment, margins entire, convex; anterior lobes $31.2-45.6 \times 38-58 \mathrm{~cm}$; posterior lobes $17.3-21.9 \times(12) 17-17.2 \mathrm{~cm}$, bicolorous, abaxially paler, matte on both surfaces; midrib narrowly rounded above to narrowly convex below; primary lateral veins 7-8 per side, recurved ascending to the collective vein, straight, curving toward margin, narrowly convex, darker than lower surface, departing midrib at $45^{\circ}-60^{\circ}$ angle; basal veins $5-8$ pairs, fused $1^{\text {st }}-5^{\text {th }}$ or $6^{\text {th }}$ to the basal ribs; interprimary and secondary veins conspicuously prominent below, slightly sunken above; collective veins arising from $4^{\text {th }}$ to $6^{\text {th }}$ pair of basal veins, marginal or to 0.3 $\mathrm{mm}$ from the margins. Inflorescence erect to erect-spreading; peduncle (21.8) $28-43.2 \mathrm{~cm}$ $\times 2-8 \mathrm{~mm}, 0.4-0.5$ longer than the petiole; drying brownish green, ribbed; spathe erect, subcoriaceous, light green to green, drying yellow-brown and weakly striate, lanceolate, (7) $9.5-12.7 \times 1.9-2.6 \mathrm{~cm}$, broadest just above the base, acuminate at apex, obtuse at base, margins forming $40^{\circ}-60^{\circ}$ angle on peduncle; spadix drying light reddish brown, cylindric to slightly tapered, erect, $5.6-9.4 \mathrm{~cm} \times 4-8$ $\mathrm{mm}$ diam., white to light green; stipe light reddish brown, $3 \mathrm{~mm}$ long in front, $2 \mathrm{~mm}$ long in back, $2 \mathrm{~mm}$ diam. Flowers rhombic, 1-1.5 $\times 1-1.5 \mathrm{~mm}$. Infructescence with berries purple tinged, white base, along twisting spadix.

Local Aguaruna names: ináimes, chinumas, or mun chinumas, muun eep, and migkáya eep.

Anthurium kusuense is known only from the Bagua and Condorcanqui Provinces (Amazonas) at 250-100 $\mathrm{m}$ in Premontane wet forest transition to Tropical (P-wf/T) life zones. The species is a member of section Cardiolonchium and is distinguished by having semi-intact cataphylls with numerous loose fibers, dark gray-green-drying, ovate- 
cordate, deeply lobed blades with collective veins not apparent and not running evenly along the margin, as well as by a spadix with 9-10 flowers per spiral. Anthurium kusuense is similar to A. shinumas, but A. shinumas differs in having intact persistent cataphylls, smaller leaf blades (less than $54 \mathrm{~cm}$ long), collective veins extending all along the margin and 4-6 $\mathrm{mm}$ from the margin, and a spadix with only 5-6 flowers pers spiral.

Anthurium kusuense is named for the collecting locality, the village of Kusu, where it was first discovered by Dr. Brent Berlin, University of California, Berkely, in March 1973.

Paratypes: PERU. AMAZONAS: Bagua, Río Cenepa, Huampami, ca. $5 \mathrm{~km}$ E of Chávez Valdívia, 4³0’S, 78³0’ W, 200-250 m, 11 July 1978, Berlin 2058 (MO); 1978, Kujikat 313 (MO); Condorcanqui, Río Cenepa, vic. of Huampami, ca. $5 \mathrm{~km}$ E of Chávez Valdivia, Quebrada Apigkan entsa, 4³0'S, 78 $30^{\circ} \mathrm{W}$, 200-250 m, 3 Aug. 1978, Kujikat 144 (MO); Chigkan entsa, Quebrada Aintami, 17 Aug. 1978, Kujikat 416 (MO); Quebrada Sasa, 250 m, 14 June 1973, Ancuash 639 (MO); village of Kusu, Río Numpatakai (tributary of Río Cenepa), 1100-1300 m, 10 Mar. 1973, Berlin 918 (MO); S of Huampami trail to house of Theodora, S of Río Cenepa, 800-850 m, 17 July 1974, Berlin 1670 (MO); trail E of Huampami to Shaim, 1 Aug. 1974, 600-1750 m, Berlin 1919 (MO); Quebrada Huampami, 640 m, 5 July 1974, Kayap 1062 (MO).

Anthurium leveauii Croat, sp. nov. Type: Perú. Amazonas: Río Santiago, ca. 65 km N de Pinglo, $1 \mathrm{~km}$ behind Caterpiza, $3^{\circ} 50^{\prime} \mathrm{S}$, 7740'W, 200 m, 7 Sep. 1979, V. Huashikat 459 (holotype, MO-2800123-4; isotype, USM). Fig. 4b.

Planta epiphytica; internodia brevia, $1-$ $1.5 \mathrm{~cm}$ diam.; cataphylla (7.7)9-12 cm longa; lamina $36.5-58.7 \mathrm{~cm}$ longa, $5.7-8.2 \mathrm{~cm}$ lata, anguste oblanceolata, anguste acuta ad basim; nervis primariis lateralibus (6)7-9(12) utroque; pedunculus $28-40 \mathrm{~cm}$ longus, 2.5-3 mm diam.; spatha ad 6-10 cm longa, viridis,
$7 \mathrm{~mm}$ lata; spadice 9-12 cm longus, 3-4 mm diam.; baccae ovoideae vel globosae, ca. 3 mm diam., roseae vel rubrae.

Epiphytic; internodes short, $1-1.5 \mathrm{~cm}$ diam.; cataphylls (7.7)9-12 cm long, persisting as $+/$ - parallel pale fibers, reddish brown at base. Petioles (8)14-17(21) cm long, terete, semiglossy, drying finely striate; geniculum 1-2 cm long, much darker than the petiole; blades $36.5-58.7 \times 5.7-8.2 \mathrm{~cm}$, (4.6)6.3-7.7(9) times longer than wide, 3.4 times longer than petioles, narrowly oblanceolate, caudate-acuminate at apex, narrowly acute at base, subcoriaceous, drying yellowish green or yellow-brown above, yellow-brown below; midrib drying concolorous and $+/$ - acute above, convex and finely ridged, slightly darker below; primary lateral veins (6)7-9(12) pair, arising at 30$35(40)^{\circ}$ angle, bluntly acute on lower surface on drying; collective veins arising from the base, $+/$ - straight to the margin, 3-6 $\mathrm{mm}$ from the margin, only weakly loop-collecting at the primary lateral veins, scarcely more prominent than the interprimary veins, more prominent than the primary lateral veins, sunken above, drying weakly raised below; upper surface minutely granular on magnification; lower surface densely glandular-punctate. Inflorescence peduncle $28-40$ $\mathrm{cm} \times 2.5-3 \mathrm{~mm}$, spathe linear, green, 10-16 $\mathrm{cm} \times 7 \mathrm{~mm}$, thin, nearly always missing in age; spadix long and slender, 9-12 cm $\times 3-4$ $\mathrm{mm}$, elongating to $41 \mathrm{~cm}$ long in fruit; green to purplish violet, drying dark brown; berries ovoid to globose, ca. $3 \mathrm{~mm}$ diam. pinkish to red.

Local Aguaruna names: úshap sugkíp, saukáp, sugkíp.

Anthurium leveauii is known only from Amazonas Department of Perú in Bagua and Condorcanqui Provinces at $180-400 \mathrm{~m}$ in Premontane wet forest transition to Tropical (P-wf/T) and Tropical moist forest (T-mf) life zones. The species is a member of section Porphyrochitonium and is characterized by a small stem, short internodes, persistent network of pale loose cataphyll fibers, long 


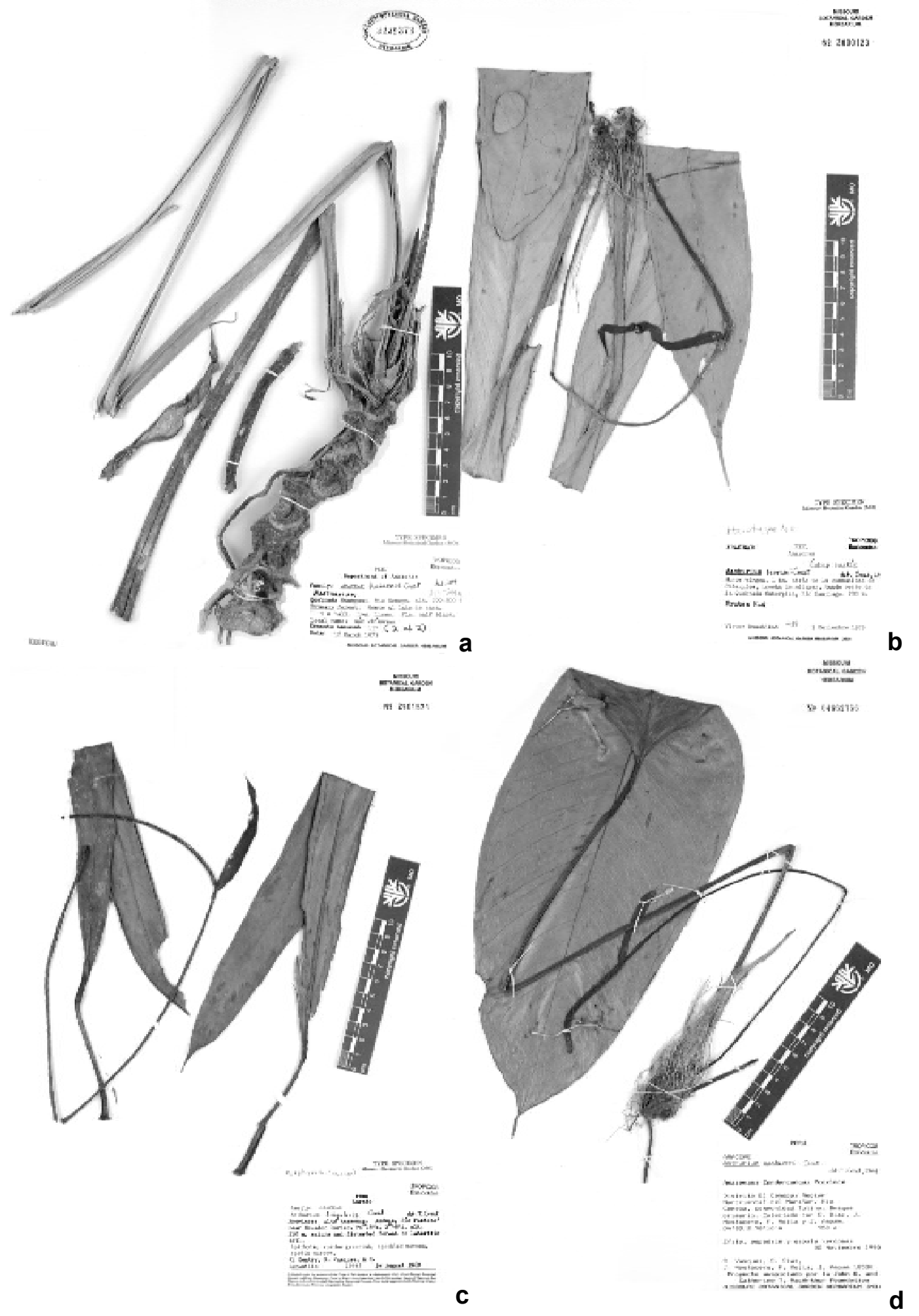

Figure 4 - a. Anthurium kusuense Croat. Type specimen. (Ancuash 137); b. Anthurium leveauii Croat. Type specimen. (Huashikat 459); c. Anthurium lingulare Croat. Type specimen. (Gentry et al. 29695); d. Anthurium mostaceroi Croat. Type specimen. (Vasquez et al. 18530) 
oblanceolate caudate-acuminate blades which dry somewhat yellowish brown and have more conspicuous collective veins than primary lateral veins on drying. In addition, the species has a slender ephemeral green spathe, a slender, scarcely tapered green to purplish violet spadix, and small globular reddish berries.

The species is very similar in leaf blade shape and drying color to $A$. huashikatii Croat, but that species has primary lateral veins that dry as conspicuous as the collective veins and has a prominently stipitate spadix. Anthurium leveauii keys out near A. apaporanum R. E. Schult., but that species has blades which are more typically oblong-elliptic, broadest in the middle with more primary lateral veins that are scarcely perceptible. In addition, $A$. apaporanum has a thicker, shorter spadix and spathe.

The species is named after José Asuncíon Leveau, a collector working with Brent Berlin on anthropological and linguistic studies with the Aguaruna and Huambisa Indians of Peru. He was the first to collect this species near the Río Santiago.

Paratypes: PERU. AMAZONAS: Bagua, Imaza, Río Marañon, Yamakat, 455'S, 78¹9’W, 320 m, 24 Nov. 1993, Vasquez et al. 18560 (MO, USM); 9 Aug. 1994, Jaramillo et al. 358 (MO, USM); 6 Oct. 1995, Jaramillo \& Katip 788A (MO); Río Kusu, 455'S, 78¹9’W, 350 m, 14 Oct. 1995, Rodrígues 502 (MO); Río Santiago, Galilea, 180 m, 16 Aug. 1979, Leveau 198 (MO); 1 km below La Poza, 180 m, 22 Aug. 1979, Leveau 263 (MO); Condorcanqui, El Cenepa, Mamayaque, 4³4'49"S, 78¹4'01"W, 400 m, 9 Aug. 1997, Rojas et al. 214 (MO, USM); Tutino, 433'05"S, 78¹2'54"W, 340, 28 July 1999, Vasquez et al. 24482 (MO, USM).

Anthurium ligulare Croat, sp. nov. Type: Perú. Loreto: Alto Amazonas, Andoas, Río Pastaza near Ecuador border, $76^{\circ} 28^{\prime} \mathrm{W}, 2^{\circ} 48^{\prime}$ S, 210 m, 14 Aug. 1980, A. Gentry, R. Vasquez \& N. Jaramillo 29695 (holotype, MO2901571). Fig. 4c.
Planta epiphytica; petioli $9.5-10.5 \mathrm{~cm}$ longi, 3-4 mm in sicco; laminae ligularis, 34$39.5 \mathrm{~cm}$ longae, 3-3.7 cm latae, cuneatae ad basim; nervis primariis lateralibus 10-12 utroque; pedunculus $38 \mathrm{~cm}$ longus; spatha viridis, lanceolata, $8.5 \mathrm{~cm}$ longa, ca. $1 \mathrm{~cm}$ lata; spadice rubiginosus, stipitatus $2 \mathrm{~mm}$, $12.5 \mathrm{~cm}$ longus, ca. $3 \mathrm{~mm}$ diam. in sicco.

Epiphytic; petioles $9.5-10.5 \mathrm{~cm}$ long, drying 3-4 mm diam.; blades strap-shaped, acuminate at apex (acumen ca. $2 \mathrm{~cm}$ long), cuneate at base, 34-39.5 × 3-3.7 cm, 9.9-11 times longer than wide, incurled at margins; upper surface eglandular, drying dark yellowish brown and matte; lower surface inconspicuously dark glandular-punctate with widely scattered warty excrescences, drying paler than above and weakly glossy; midrib concolorous, prominently raised near base, becoming flatter near apex on both surfaces, slightly darker below; primary lateral veins 10-12 per side, only slightly more prominent than interprimary veins; collective veins arising from near base, much more prominent than primary lateral veins, almost as prominent as midrib near apex, noticeably sunken above, 3-4 $\mathrm{mm}$ from margin. Inflorescence with peduncle $38 \mathrm{~cm}$ long, drying 2-3 mm diam.; spathe erect, greenish, speckled maroon, lanceolate, $8.5 \mathrm{~cm}$ long, ca. $1 \mathrm{~cm}$ wide at widest portion near base, narrowly acuminate; spadix maroon, stipitate $2 \mathrm{~mm}$, arching away from spathe to almost a $90^{\circ}$ angle, $12.5 \mathrm{~cm}$ long, drying ca. $3 \mathrm{~mm}$ diam. Flowers $1.5-1.9 \times 1.1-1.3 \mathrm{~mm}, 3$ visible per spiral; lateral tepals $0.8-1 \mathrm{~mm}$ wide, outer margins 2-sided.

Anthurium ligulare is known only from the type locality in northern Perú in the Province of Alto Amazonas, Loreto Department at $210 \mathrm{~m}$ in Premontane wet forest (P-wf) and Tropical moist forest (T-mf). It is likely to be found in Amazonas Department as well. It a member of section Porphyrochitonium and is characterized by its strap-shaped blades (hence the epithet "ligulare") with prominently sunken collective veins on the upper surface and its 
long slender spathe. It is closest to A. diazii, which is also somewhat longer than wide and has a fairly long spathe. However, A. diazii is terrestrial, has much more elliptic blades, and a green spathe and spadix.

Anthurium mostaceroi Croat, sp. nov. Type: Perú. Amazonas: Condorcanqui, El Cenepa, Región Nororienatal del Marañon, Río Cenepa, Tutino, $4^{\circ} 33^{\prime} \mathrm{S}, 78^{\circ} 10^{\prime} \mathrm{W}, 750 \mathrm{~m}, 22$ Nov. 1993. R. Vasquez, C. Diaz, J. Mostacero, F. Mejia \& J. Ampam 18530 (holotype, MO04662756, isotype, USM). Fig. 4d.

Planta epiphytica; internodia brevia, 1.5 $\mathrm{cm}$ diam. in sicco; cataphylla $13 \mathrm{~cm}$ longa; petioli $52.7 \mathrm{~cm}$ longi, $3 \mathrm{~mm}$ diam. in sicco; laminae late ovatae, attenuatae ad basim, 37 $\mathrm{cm}$ longae, $15 \mathrm{~cm}$ latae; nervis primariis lateralibus 15-18 utroque; pedunculus $32 \mathrm{~cm}$ longus, $1 \mathrm{~mm}$ diam. in sicco; spatha viridis, 5.7 $\mathrm{cm}$ longa, $1.1 \mathrm{~cm}$ lata; spadice viridis, $8 \mathrm{~cm}$ longus, $4 \mathrm{~cm}$ diam. in sicco.

Epiphytic, internodes short, drying 1.5 $\mathrm{cm}$ diam.; cataphylls $13 \mathrm{~cm}$ long, tan, persisting as linear fibers. Petioles $52.7 \mathrm{~cm}$ long, drying $3 \mathrm{~mm}$ wide, grayish brown; geniculum darkened, $2.5 \times 3 \mathrm{~cm}$; blades broadly ovate, slightly inequilateral, one side up to $1 \mathrm{~cm}$ wider, abruptly and narrowly acuminate at apex, attenuate at base, $37 \times 15$ $\mathrm{cm}, 2.5$ times longer than broad, 0.7 times the length of the petiole, drying olive green, weakly glossy, eglandular above, paler and more brownish, semi-glossy, glandularpunctate below; midrib narrowly convex, drying $1 \mathrm{~mm}$ diam., brownish above, convex, darker than blade surface below; primary lateral veins $15-18$ per side, $1-2 \mathrm{~cm}$ apart, departing from the midrib at a $50-60^{\circ}$ angle, concolorous above, slightly darker than surface below, somewhat prominent on both surfaces; collective veins arising from near base, prominently loop-connected, as equally prominent as primary veins, $1 \mathrm{~cm}$ from margin to less than $1 \mathrm{~mm}$ from margin near apex. Inflorescences with peduncle $32 \mathrm{~cm}$ long, drying $1 \mathrm{~mm}$ diam., darkened; spathe reflexed-spreading, green, linear, $5.7 \times 1.1 \mathrm{~cm}$,
0.2 times the length of peduncle, abruptly and narrowly acuminate at apex, apex $3 \mathrm{~mm}$ long; spadix green, cylindrical, erect, $8 \mathrm{~cm}$ long, drying $4 \mathrm{~cm}$ diam. Flowers $2 \times 1.8 \mathrm{~mm}, 4-5$ visible per spiral; lateral tepals $1 \mathrm{~mm}$ wide, two-sided.

Anthurium mostaceroi is endemic to the type locality in northern Perú at $750 \mathrm{~m}$ in Premontane wet forest (P-wf) or Tropical moist forest (T-mf) life zones. It is a member of section Porphyrochitonium and is characterized by its long cataphylls and large, broad, ovate blades. It is similar to $A$. quipuscoae Croat, also published in this manuscript, but that species has smaller cataphylls, is broader with respect to length, and more abrupt at the apex.

The species is named in honor of $\mathrm{J}$. Mostacero one of the collectors of the type specimen. Mr. Mostacero was a collector for Dr. Brent Berlin's Río Marañón expeditions in the Río Santiago and Río Cenepa areas.

Anthurium penae Croat, sp. nov. Type: Perú. Amazonas: Bagua, Imaza, Aguaruna Putuim, anexo Yamayakat, Zona de Colinas altas $24^{\circ} \mathrm{SW}$ of Putuim, 700-820 m, 23 Sep. 1994, C. Díaz, A. Peña \& P. Atamain 7204 (holotype, MO-05095094, isotypes, K, US, USM). Fig. 5a.

Planta epiphytica; internodia brevia, $1-1.5 \mathrm{~cm}$ diam. in sicco; cataphylla 4.2-8.2 cm longa; petioli $4.5-18.5 \mathrm{~cm}$ longi, $2-3 \mathrm{~mm}$ diam. in sicco; laminae ellipticae, $14-22 \mathrm{~cm}$ longae, $4.4-8.9 \mathrm{~cm}$ latae; nervis primariis lateralibus 6-7 utroque; pedunculus 17.5-26 cm longus; spatha oblonga, $2.8-3.5 \mathrm{~cm}$ longa, 5-7 mm lata; spadice purpureus vel atroruber, cylindricus, 7-14.5 cm longus, 5$9 \mathrm{~mm}$ diam.

Epiphytic; stems drying dark brown; leaf scars $5-6 \mathrm{~mm} \times 1-1.5 \mathrm{~cm}$; internodes short, drying $1-1.5 \mathrm{~cm}$ diam.; cataphylls $4.2-8.2 \mathrm{~cm}$ long, drying reddish brown, persisting at upper nodes as almost intact to pale linear fibers near apex, as a reticulum near base, eventually deciduous, acute to acuminate at apex. Petioles $4.5-18.5 \mathrm{~cm}$ long, drying $2-3 \mathrm{~mm}$ 
diam., sharply sulcate above, drying light green to brown-yellow; geniculum slightly thicker than petiole, darkened, 7-12 mm long, drying 3-4 mm diam.; blades +/- elliptic, obtuse to rounded or emarginate at apex, cuneate to slightly attenuate at base, 14-22 $\mathrm{cm}$ long, averaging $17.9 \mathrm{~cm}, 4.4-8.9 \mathrm{~cm}$ wide, averaging $6.2 \mathrm{~cm}, 2.5-3.1$ times longer than broad, averaging 2.9 times longer, broadest at or slightly above middle, revolute at margins; upper surface drying yellowish green; lower surface brownish green, tinged with gray, glandular-punctate; midrib convex, sometimes flat, sometimes sunken above, drying ca. $0.5-1 \mathrm{~mm}$ diam., concolorous, narrowly convex below, drying 1-2 mm wide, concolorous; primary lateral veins $6-7$ per side, about $1.2-2.2 \mathrm{~cm}$ apart where they arise from the midrib, arsing at a $30^{\circ}-35^{\circ}$ angle from the midrib, straight to the collective vein, concolorous, sometimes drying sunken with an irregular ridge along both margins, sometimes slightly raised above, slightly loop-connected above and below; interprimary veins almost as conspicuous as primary veins, usually one, sometimes two between each primary vein; collective veins arising from near base, concolorous, more prominent than primary veins, 5-11 $\mathrm{mm}$ from margin. Inflorescence with peduncle $17.5-26 \mathrm{~cm}$ long, averaging $22.8 \mathrm{~cm}$, drying 1-4 $\mathrm{mm}$ diam., reddish brown; spathe reflexed-spreading to reflexed, red or purple, sometimes tinged with green, oblong, $2.8-3.5 \mathrm{~cm} \times 5-7 \mathrm{~mm}$, held at a $155^{\circ}-$ $180^{\circ}$ angle on peduncle, acute or apiculate at apex; spadix purple or dark red, cylindrical, curved away from spathe, spreading to $45^{\circ}$ $90^{\circ}$ angle, $7-14.5 \mathrm{~cm} \times 5-9 \mathrm{~mm}$. Flowers ca. $3 \times 2 \mathrm{~mm}, 3-4$ visible per spiral, lateral tepals $2 \mathrm{~mm}$ wide, margins 2 -sided. Infruvtescences $8.6 \mathrm{~cm}$ long, drying $1.6 \mathrm{~cm}$ diam., setting berries in lower $1 / 2$ to $3 / 4$ of its length, berries pink.

Anthurium penae is known only to northern Perú at $430-800 \mathrm{~m}$ in Premontane wet forest transitioning to Tropical $(\mathrm{P}-\mathrm{wf} / \mathrm{T})$ life zone. It is a member of section
Porphyrochitonium and is characterized by small, yellowish green, elliptic blades with rounded to emarginate apices and prominent collective veins. It is very similar to $A$. tsamajainii, which also has small, yellowish green, elliptic blades, but that species has blades that are narrowly acute or even weakly acuminate at the apex.

The species is named in honor of Antonio Peña, Peruvian plant collector and excellent parataxonomist, who was part of the team working with Rodolfo Vasquez in Oxapampa, Peru, that collected the type specimen.

Paratypes: PERU. AMAZONAS: Condorcanqui, El Cenepa, Region Nororiental del Marañon, Río Cenepa, Tutino, 4³3'S, $78^{\circ} 10^{\prime} \mathrm{W}, 750 \mathrm{~m}, 22$ Nov. 1993, Vasquez et al. 18533 (MO); Bagua, Imaza, Tayu Mujaji,

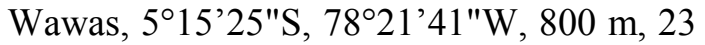
Oct. 1997, Rojas et al. 461 (MO); Aguaruna de Wanás, km 92 Carretera Bagua-Imacita, Cherros Chunim, 700-800 m, 29 Aug. 1996, Diaz et al. 8070 (MO); Quebrado E1 Almendro, along creek and on sandstone, $5^{\circ} 14^{\prime} 40^{\prime \prime} \mathrm{S}, 7^{\circ} 21$ '24"W, $430 \mathrm{~m}, 9$ Mar. 1998, van der Werff et al. 14576 (MO).

Anthurium quipuscoae Croat, sp. nov. Type: Perú. Amazonas: Bagua, Imaza, Yamayakat, NE of Marañon RENOM, rd. to Putuín, $4^{\circ} 55^{\prime}$ 'S, $78^{\circ} 19^{\prime} \mathrm{W}, 350-430 \mathrm{~m}, 17$ Oct. 1995, V. Quipuscoa S. 288 (holotype, MO05053799, isotype, USM). Fig. 5 b.

Planta terrestris; internodia $2 \mathrm{~cm}$ diam. in sicci; cataphylla $8 \mathrm{~cm}$ longa; petiolus 54 cm longus; lamina late ovata vel late elliptica; $31 \mathrm{~cm}$ longa, $19 \mathrm{~cm}$ lata; nervis primariis lateralibus 15 utroque; pedunclus $33.5 \mathrm{~cm}$ longus; spatha rubra; spadice cylindricus, 4.4 longus, $4 \mathrm{~mm}$ diam. in sicco.

Terrestrial; internodes drying $2 \mathrm{~cm}$ diam.; cataphylls $8 \mathrm{~cm}$ long, pale tan, persisting at upper internodes as longitudinal fibers. Petioles $54 \mathrm{~cm}$ long, drying $3 \mathrm{~mm}$ wide, dark yellowish brown; geniculum approximately same shape as petiole, slightly darkened, $1.5 \mathrm{~cm} \times 4 \mathrm{~mm}$; blades broadly 

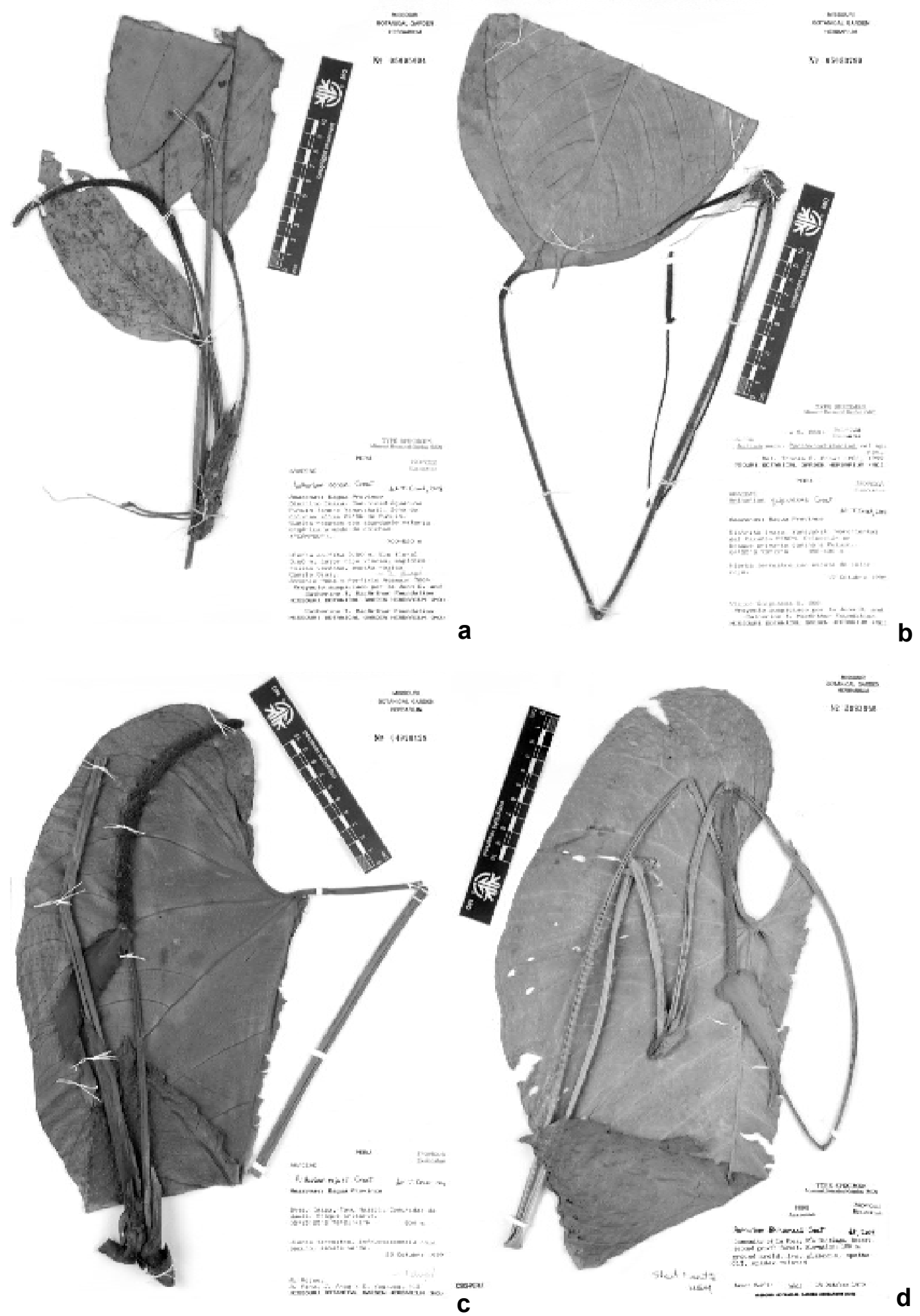

Figure 5 - a. Anthurium penae Croat. Type specimen. (Díaz et al. 7204); b. Anthurium quipuscoae Croat. Type specimen. (Quipuscoa 288); c. Anthurium rojasiae Croat. Type specimen. (Rojas et al. 413); d. Anthurium shinumas Croat. Type specimen. (Berlin 3602) 
ovate to broadly elliptic, very abruptly acuminate at apex (acumen $2.7 \mathrm{~cm}$ long), cuneate to rounded at base, $31 \times 19 \mathrm{~cm}, 1.6$ times longer than wide, 0.57 times length of petiole, drying light brownish green, matte to weakly glossy, eglandular above, pale brown, semi-glossy, glandular-punctate below; midrib drying broadly convex to convex, concolorous to slightly darker below; primary lateral veins 15 per side, $1.2-2.5 \mathrm{~cm}$ apart, departing midrib at a $45-50^{\circ}$ angle, concolorous above, concolorous to slightly darker than surface below; collective veins arising from near base, equally prominent as primary veins, $4-7 \mathrm{~mm}$ from margin. Inflorescence with peduncle 33.5 $\mathrm{cm}$ long, drying $2 \mathrm{~mm}$ diam., drying dark reddish brown; spathe red; spadix cylindrical, erect, 4.4 $\mathrm{cm}$ long, drying $4 \mathrm{~mm}$ diam. Flowers $2.5 \times 2$ cm, 4-5 visible per spiral; lateral tepals $1 \mathrm{~cm}$ wide, outer margins 2-sided.

Anthurium quipuscoae is endemic to the type locality in northern Perú at 350-430 m in Premontane rain forest (P-rf) life zone. It is a member of section Porphyrochitonium and is characterized by large, extremely broad ovate or elliptic blades that are only 1.6 times longer than wide and a very abruptly acuminate apex. The species keys out near $A$. mostaceroi, but that species differs in having ovate-elliptic blades which are 2.5 times longer than wide versus ovate-elliptic and 2.5 times longer than wide in A. quispuscoae.

The species is named in honor of Victor Quispuscoa S., a Peruvian collector who collected the type specimen.

Anthurium rojasiae Croat, sp. nov. Type: Perú. Amazonas: Bagua, Río Cenepa, Imaza, Tayu Mujaji, Wawas, 5०15'25"S, 78²1'41"W, 800 m, 23 Oct. 1997, R. Rojas, A. Peña, J. Anag \& E. Yagkuag 413 (holotype, MO-04920428; isotypes, AMAZ, HUT, USM).

Fig. 5c.

Planta terrestris; internodia brevia, $1-$ $1.8 \mathrm{~cm}$ diam.; cataphylla $10.5-16 \mathrm{~cm}$ longa; petioli 39-64 cm longi, 5-8 $\mathrm{mm}$ diam.; laminae late ovato-cordatae, $35-42.2 \mathrm{~cm}$ longae, $26.5-36 \mathrm{~cm}$ latae; lobulae posteriores, $13.5-17 \mathrm{~cm}$ longae, $12-13.5 \mathrm{~cm}$ latae; nervis primariis lateralibus 4-5 utroque; pedunculus $15.5-20 \mathrm{~cm}$ longus, 3-5 mm diam. in sicco; spatha viridis vel crema, oblongaelliptica, $10-13.5 \mathrm{~cm}$ longa, $1.8-2.7 \mathrm{~cm}$ wide; spadice rubrus, $15-18 \mathrm{~cm}$ longus, $7-8 \mathrm{~mm}$ diam. in sicco.

Terrestrial; internodes short, drying 1$1.8 \mathrm{~cm}$ diam.; cataphylls $10.5-16 \mathrm{~cm}$ long, weakly ribbed, drying brown to reddish brown, lanceolate, persisting at upper internodes intact, acute at apex. Petioles 39$64 \mathrm{~cm} \times 5-8 \mathrm{~mm}, 1.1-1.4$ times longer than blades, drying reddish brown; geniculum as broad as or thicker than petioles, blackened or concolorous, $2-3 \mathrm{~cm}$ long, drying $4-5 \mathrm{~cm}$ diam.; blades broadly ovate-cordate, acuminate (acumen 1-1.3 cm long with short apiculum ca. $1 \mathrm{~mm}$ long), 35-42.2 × 26.5-36 $\mathrm{cm}, 1.1-1.3$ times longer than wide, drying dark yellowish brown, weakly glossy above, medium-dark reddish brown, semi-glossy, dark punctate below; anterior lobe 27-32.5 $\mathrm{cm}$ long, broadest above the petiole attachment, broadly convex alng margins; posterior lobes $13.5-17 \times 12-13.5 \mathrm{~cm}$, directed downwards; midrib broadly convex to convex with acute margins, drying to $1 \mathrm{~mm}$ wide, concolorous above, broadly convex to convex, prominently raised with an acute medial rib, $+/$ - concolorous below; primary lateral veins $4-5$ per side, $2.5-4.5 \mathrm{~cm}$ apart, departing midrib at a $45^{\circ}-55^{\circ}$ angle and extending nearly straight to a collective vein, flat to broadly convex below, raised above, conspicuous and drying concolorous, more prominent than interprimary veins on both surfaces; basal veins $5-6$ per side, $1^{\text {st }}$ and usually the $2^{\text {nd }}$ pairs free to base, $4^{\text {th }}$ and $5^{\text {th }}$ coalesced to 2-3.8 cm; basal rib naked for 1.5$2.5 \mathrm{~cm}$ along sinus; collective veins arising from $1^{\text {st }}$ pair of basal veins but often weakly loop-connected with the $2^{\text {nd }}$ or $3^{\text {rd }}$ pair of basal veins, $1-3 \mathrm{~mm}$ from margin, less prominent than primary lateral veins; reticulate veins prominently raised. Inflorescence erect; peduncle $15.5-20 \mathrm{~cm}$ long, drying $3-5 \mathrm{~mm}$ 
diam., drying reddish brown; spathe reflexedspreading, green or creamy white, narrowly oblong-elliptic, $10-13.5 \times 1.8-2.7 \mathrm{~cm}$, acuminate at apex (acumen inrolled, ca. 4-5 $\mathrm{mm}$ long); spadix red, cylindroid-tapered, erect, $15-18 \mathrm{~cm}$ long, drying 7-8 $\mathrm{cm}$ diam. Flowers $1.8 \times 1.4 \mathrm{~mm}, 10-11$ visible per spiral; lateral tepals $1 \mathrm{~mm}$ wide, broadly rounded on inner margin, 2-sided on outer margin.

Anthurium rojasiae is only known from the type locality in northern Perú at $800 \mathrm{~m}$ in Premontane wet forest transition to Tropical (P-wf/T), and Tropical Lower Montane wet forest (TLM-wf) life zones. It is a member of section Calomystrium that is characterized by its dark red spadix and large reddish browndrying, punctate blades with only 4-5 primary lateral veins.

The species can be compared with $A$. grande N. E. Br. which differs from $A$. rojasiae in having blades 1.9 times longer and a greenish yellow spadix, in contrast to leaf blades 1.1-1.3 times longer than wide, and a red spadix for $A$. rojasiae.

This species is named for the collector, Rosie Rojas, Peruvian botanist and wife of Rodolfo Vasquez, who made many collections of Araceae in the Río Cenepa region and collected the type specimen.

Anthurium shinumas Croat, sp. nov. Type: La Poza, Río Santiago, 180 m, 15 Oct. 1979, B. Berlin 3602 (holotype, MO-2893958; isotype, USM). Fig. 5d.

Planta terrestris vel rarius epiphytica; internodia $0.5-1.5 \mathrm{~cm}$ longa, $1.1-2.8 \mathrm{~cm}$ diam.; cataphylla 6-11(-18) cm longa; petioli (25.5-) $38.5-82 \mathrm{~cm}$ longi, 3-5 mm diam. in sicco; lamina ovato-cordata, lobulata ad basim, $32.5-$ $54 \mathrm{~cm}$ longa, $22-33 \mathrm{~cm}$ lata; nervis primariis lateralibus $7-10$ utroque; pedunculus 20-48.5 cm longus; spatha $8-12.5 \mathrm{~cm}$ longa, $0.8-2.1 \mathrm{~cm}$ lata; spadice 5.5-12.5 cm longus, 4-7 mm diam. in sicco.

Terrestrial or rarely epiphytic; internodes usually less than $5 \mathrm{~mm}$ long at lower internodes, sometimes up to $1.5 \mathrm{~cm}$ at uppermost internodes, drying $1.1-2.8 \mathrm{~cm}$ diam., tan; cataphylls 6-11 (-18) cm long, unribbed or weakly 1-ribbed, drying reddish or greenish gray, lanceolate, persisting intact at upper internodes only, then quickly deciduous or remaining as small fragments. Petioles (25.5-) 38.5-82 cm long (averaging $56 \mathrm{~cm}$ ), drying 3-5 mm diam., drying deeply grooved, gray, faintly tinged with red or green, sometimes sulcate adaxially; geniculum terete (or at least not grooved), often slightly darkened, $1.5-2.5 \mathrm{~cm}$ long, drying 3-4 mm diam., smooth; blades +/- ovate-cordate, gradually acuminate to acute at apex, often apiculate, lobed at base, $32.5-54 \mathrm{~cm}$ long (averaging $41.2 \mathrm{~cm}$ ), 22-33 $\mathrm{cm}$ wide (averaging $25.3 \mathrm{~cm}$ ), 1.5-1.7 times longer than wide, $0.6-1(-1.3)$ times the length of the petiole, usually broadest at or just above the point of petiole attachment, drying dark graygreen, occasionally faintly tinged with red above, paler, light gray-green below; anterior lobe $25-39 \mathrm{~cm}$ long, $14-27 \mathrm{~cm}$ wide at midpoint, 1.3-2 times longer than wide, 1.9$2.3(-2.6)$ times longer than posterior lobe, broadest near base, convex to straight along margins; posterior lobes rounded, 11-17 × 6$11 \mathrm{~cm}$, sometimes broadest at base, sometimes broadest near middle, directed more or less inward; sinus hippocrepiform to spathulate, $7.5-15 \mathrm{~cm}$ deep; midrib almost flat to broadly convex, drying 1-2 mm wide, concolorous or sometimes slightly paler than surface above, narrowly convex, thicker than broad, prominently raised, white, conspicuously paler than surface, sometimes ridged, speckled below; primary lateral veins $7-10$ per side, $1-3.5(-4.5) \mathrm{cm}$ apart, departing midrib at a $35^{\circ}-50^{\circ}$ angle, concolorous to slightly paler than surface, convex to narrowly rounded above, much paler, raised below, curving towards margins; basal veins 5-7 per side, with first and second free to base, $4^{\text {th }}$ and higher coalesced $2.5-4 \mathrm{~cm}$, conspicuously paler below; posterior rib naked $2.5-4.5 \mathrm{~cm}$ along sinus; collective veins not conspicuous (or if there is one, it arises from the middle of the blade and is then less than $1 \mathrm{~mm}$ form 
margin). Inflorescence with peduncle 20-48.5 $\mathrm{cm}$ long, drying 3-4 mm wide, gray to grayish red; spathe usually spreading to reflexed; sometimes green, lanceolate to oblong, 8-12.5 $\times 0.8-2.1 \mathrm{~cm}$, generally acute at apex; spadix purple or brown, often somewhat tapered, sometimes slightly stipitate (with stipe less than $2 \mathrm{~mm}$ ), often curved, $5.5-12.5 \mathrm{~cm}$ long, drying 4-7 mm diam., 9.7-25 times longer than wide (usually more than 15 times longer than wide). Flowers 2-2.6 × 1.8-1.9 mm, 56 visible per spiral; lateral tepals $1-1.2 \mathrm{~mm}$ wide, 3-sided, shield shaped.

Local Aguaruna names: shinumas, shinúmas éep.

Anthurium shinumas is known only to northern Perú in the Río Cenepa-Río Santiago region at 180-200 (-700) $\mathrm{m}$ in Premontane wet forest transition to Tropical (P-wf/T), and likely Tropical wet forest (T-wf) as well. It is characterized by greenish-gray drying blades, very pale venation on the lower blade surfaces, and posterior lobes directed more or less inward.

The species is similar to A. kusuense, in the shape and color of the blade and venation, but $A$. kusuense has cataphylls that weather to fibers instead of persisting intact, much longer petioles, wider blades, and spadices with more flowers visible per spiral. One collection, Berlin 3699, could possibly be $A$. shinumas because its blades have a similar drying color with somewhat pale white venation beneath and a white spadix with somewhat similarly shaped lateral tepals. However, the posterior lobes of the blades of Berlin 3699 are directed more or less outward instead of inward as in A. shinumas.

The species is named for the common Aguaruna Indian name for the species, "shinumas".

Paratypes: PERU. AMAZONAS: Bagua, Río Cenepa region, Monte del isla, la isla $1 \mathrm{~km}$, bajo de La Poza, 180 m, 8 Aug. 1979, Leveau 8 (MO); Condorcanqui, above Quebrada Tuhusik, 5 min. down river from Chavez Valdivia, 213-244 m, 16 Dec. 1972, Berlin 579 (MO); Río Santiago, 180 m, Huashikat
1237 (MO); ca. 65 km al N de Pinglo, 200 m, 12 Feb. 1980, Huashikat 2051 (MO); 2 km below Caterpiza, Río Santiago, 200 m, 13 Sep. 1979, Huashikat 606 (MO); $1 \mathrm{~km}$ behind La Poza, 180 m, 12 Nov. 1979, Tunqui 12 (MO); Río Santiago valley, ca. $65 \mathrm{~km} \mathrm{~N}$ de Pinglo, 2-3 km behind Caterpiza, $200 \mathrm{~m}, 15 \mathrm{Feb}$. 1980, Huashikat 2094 (MO).

Anthurium tsamajainii Croat, sp. nov. Type: Perú. Amazonas: Bagua, Imaza, Aguaruna Putuim, annex Yamayakat, zona de Colinas altas $24^{\circ}$ SW de Putuim, 700 m, 22 Sep. 1994 , C. Díaz, A. Peña \& P. Atamain 7196 (holotype, MO-05095095; isotypes, USM). Fig. 6a.

Planta epiphytica vel terrestris, ca. 0.5 $m$ alta; internodia brevia, $8-10 \mathrm{~mm}$ in sicco; cataphylla 3-5.5 cm longa; petioli 4.5-17.5 $\mathrm{cm}$ longi, $1-2 \mathrm{~mm}$ diam. in sicco; laminae ellipticae, 10-23.5 cm longae, $2.5-6.1 \mathrm{~cm}$ latae; nervis primariis lateralibus 4-6(-7) utroque; pedunculus 15-29.5 cm longus; spatha 2-3.5 cm longa, ca. $4 \mathrm{~mm}$ lata; spadice viridis, ca. $7 \mathrm{~cm}$ longus, $4 \mathrm{~mm}$ diam. in sicco.

Epiphytic or terrestrial ca. $0.5 \mathrm{~m}$ tall; internodes short, drying $8-10 \mathrm{~mm}$ diam.; cataphylls 3-6 (-9) cm long, drying usually red to brown, lanceolate, persisting at upper nodes as a reticulum of fibers, apex sometimes remaining intact. Petioles $4.5-17.5 \mathrm{~cm}$ long (averaging $11 \mathrm{~cm}$ long), drying 1-3 (-4) $\mathrm{mm}$ diam., yellow-brown, sulcate above; geniculum slightly thicker than petiole, darkened, 5-20(-30) × 2-5 mm; blades elliptic to oblong elliptic, acute to gradually acuminate at apex, (acumen 0.5-2 cm long), cuneate or slightly attenuate at base, (8-) 10 $23.5 \mathrm{~cm}$ long, (averaging $17.9 \mathrm{~cm}$ long), $2.5-$ $7.5 \mathrm{~cm}$ wide (averaging $4.5 \mathrm{~cm}$ wide), $2.4-5$ times longer than broad, 1.2-3.4 times longer than petiole, broadest near middle, margins slightly revolute; upper surface drying grayish green to yellow green; lower surface drying brownish green, tinged with gray and sometimes reddish brown; midrib fairly uniform throughout on both surfaces, broadly convex, sometimes sunken, drying less than 

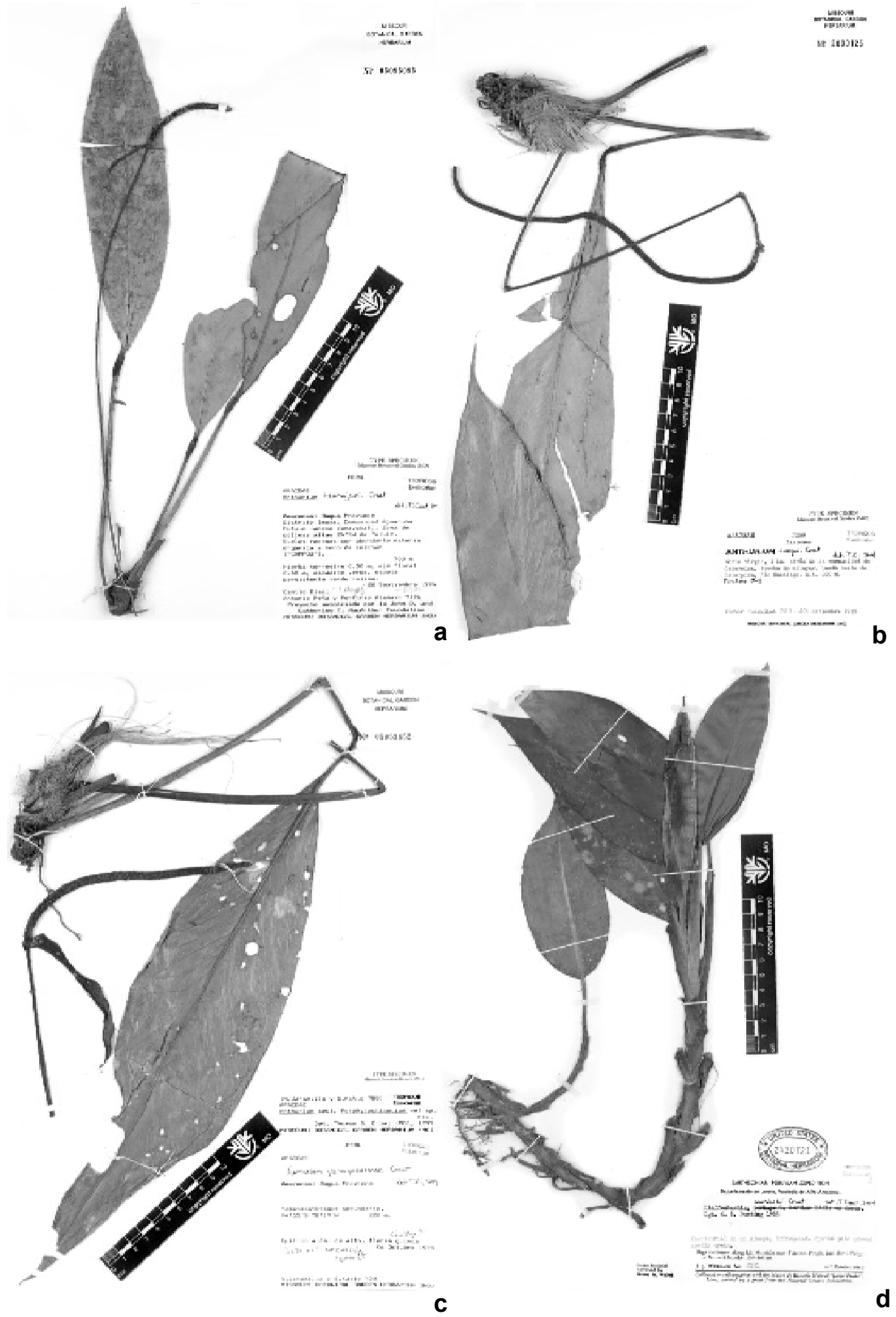

Figure 6 - a. Anthurium tsamajainii Croat. Type specimen. (Díaz et al. 7196); b. Anthurium tunquii Croat. Type specimen. (Huashikat 723); c. Anthurium yamayakatense Croat. Type specimen. (Jaramillo \& Katip 788); d. Dieffenbachia wurdackii Croat. Type specimen. (Wurdack 2131) 
$1 \mathrm{~mm}$ diam., and concolorous above, narrowly raised and concolorous to slightly paler below; primary lateral veins $4-6(-7)$ per side, ca. $2 \mathrm{~cm}$ apart, arising at a $20-40^{\circ}$ angle from the midrib, straight, loop-connected to the collective veins, concolorous, sometimes scarcely more prominent than interprimary veins, sometimes drying sunken with an irregular ridge extending along both margins, sometimes bluntly raised; collective veins arising from base, as prominent as primary lateral veins, $3-11 \mathrm{~mm}$ from margin. Inflorescence with peduncles $15-29.5 \mathrm{~cm}$ long, drying 1-3 mm diam., 1.3-2.2 times longer than petiole, drying dark reddish brown; spathe erect when immature, becoming reflexed-spreading to reflexed, red to purple, sometimes pink, green or tinged with green, linear, sometimes with a subapical apiculum $2 \mathrm{~mm}$ long, sometimes furled inward, 2-3.5 cm long, ca. 2-4 mm wide, ca. $0.11-0.13$ times the length of peduncle, 0.5 times length of spadix, sharply acuminate; spadix green to pink (red on infructescence), sometimes purple, curved away from spathe, spreading to an almost $90^{\circ}$ angle, ca. 6-9 cm long, drying $4 \mathrm{~mm}$ diam. Flowers $2.5 \times 2 \mathrm{~mm}$, $3-5$ visible per spiral, lateral tepals $1 \mathrm{~mm}$ long, outer margins 2-sided, concave.

Anthurium tsamajainii ranges from Ecuador (Sucumbios, Napo, Pastaza, Morona-Santiago) to northern Peru (Amazonas) at 300-1300 $\mathrm{m}$ in the Premontane wet forest transitioning to Tropical (P-wf/T) life zone.

The species is a member of $A$. sect. Porphyrochitonium, and is characterized by small, yellowish green to grayish green elliptic blades and long peduncles. In addition, the spadix is usually reddish. Although the cataphylls are typically reddish to brownish, one specimen, Madison et al. 3310, from Cordillera de Cutucú, was found to have very light tan colored cataphylls. Finally, we note that the spadix of $A$. tsamajainii is green while the spathe is purple. However, the herbarium label for Freire \& Santi 3315, from Pastaza has these colors reversed with the spadix purple and the spathe green. It is unclear if this is a mistake or if $A$. tsamajainii can actually have a purple spadix and a green spathe.

It is very close to $A$. pennae, but that species has rounded to emarginated blades, somewhat shorter peduncles, and a more prominent collective vein.

The species is named for L. Tsamajain who collected along with C. Díaz, A. Peña, and M. Roca in the Río Cenepa area, and has contributed extensively to collection of specimens in this area.

Paratypes. ECUADOR. MORONA-SANTIAGO: Cordillera de Cutucú, Madison et al. 3310 (SEL). NAPO: Cantón Archidona, Carretera Hollín Loreto, Rio Huataraco, Cerón et al. 7625 (QCNE); Tena, Jatun Sacha, Delinks \& Suarez 194 (MO); 230 (MO); Palacios 2454 (MO); 4329 (QCNE); Cerón 771 (QCNE); Cerón 1630 (QCNE); Palacios et al. 5138 (QCNE); Rio Napo, $14 \mathrm{~km}$ al E de Puerto Napo, $9 \mathrm{~km}$ al E de Atahualpa, Palacios et al. 1551 (MO); Sumaco, Cerón et al. 5302 (MO); $10 \mathrm{~km} \mathrm{~N}$ of Lago Agrio on road to Rio San Miguel, Oldeman et al. 36 (QCA, US). PASTAZA: Cantón Arajuno, Freire et al. 3315 (MO). PERU. AMAZONAS: Bagua, Imaza, Aguaruna de Wanás, km 92 Carretera Bagua-Imacita, Cerros Chinim, Díaz et al. 8119 (MO, USM); Condorcanqui, El Cenepa, Mamayaque, Cerro Sakee-gaig, Vásquez et al. 22592 (MO).

Anthurium tunquii Croat, sp. nov. Type: Perú. Amazonas: $1 \mathrm{~km}$ W of Caterpiza, W of Caterpiza, Río Santiago, 200 m, 20 Sep. 1979, V. Huashikat 723 (holotype, MO-2800125; isotype, USM). Fig. 6 b.

Planta epiphytica; internodia brevia, 1.2-2 cm diam. in sicco; cataphylla 9.5-14 cm longa; petioli $21.5-25.5 \mathrm{~cm}$ longi, 2-5 mm in sicco; laminae oblonga vel oblongoelliptica, 37-40 (-46) cm longae, $7.5-8 \mathrm{~cm}$ latae; nervis primariis lateralibus $10-13$ utroque; pedunculus 28-39 (-50) cm longus; spatha $4.5-5 \mathrm{~cm}$ longa, $6 \mathrm{~mm}$ lata; spadice 5-8 (-21) cm longus, 3-4 mm diam. in sicco. 
Epiphytic; internodes short, drying 1.2$2 \mathrm{~cm}$ diam.; cataphylls $9.5-14 \mathrm{~cm}$ long, tan, weathering to a large reticulate mass with some longitudinal fibers closer to the apex. Petioles 21.5-25.5 cm long, drying 2-5 mm diam., yellowish brown; blades oblong to oblong-elliptic, acuminate (acumen $2.5-3 \mathrm{~cm}$ long), cuneate to attenuate at base, 37-40 (46) $\times 7.5-8 \mathrm{~cm}$, eglandular, pale to medium brownish green, sometimes more yellowish brown above, closely dark glandular-punctate, yellowish brown tinged with gray below; midrib convex, brown to concolorous above, convex and slightly more raised, concolorous below; primary lateral veins $10-13$ per side, scarcely more prominent than interprimary veins; collective veins arising from near base, as prominent as primary lateral veins, $4-6 \mathrm{~mm}$ from margin, sometimes a very faint, short, secondary collective vein exists, ending about $1.3 \mathrm{~cm}$ from base. Inflorescences with peduncle 28-39 (-50) cm long, drying 2-3 $\mathrm{mm}$ diam.; spathe erect or reflexed-spreading, oblong-elliptic, $4.5-5 \mathrm{~cm} \times 6 \mathrm{~mm}$ at widest part near base unfurled, acuminate; spadix reddish brown, cylindrical, erect but sometimes arching to a $90^{\circ}$ angle, 5-8 (-21) $\mathrm{cm}$ long, drying 3-4 mm diam. Flowers 1.6$1.9 \times 1.2-1.3 \mathrm{~mm}, 4-5(-6)$ visible per spiral; lateral tepals $0.9 \mathrm{~mm}$ wide, outer margins 2 sided.

Local Aguaruna name: idaimas.

Anthurium tunquii is known from northern Perú from 200-300 $\mathrm{m}$ in Tropical wet forest (T-wf), Premontane wet forest (Pwf) and Tropcial moist forest (T-mf) life zones. It is a member of section Porphyrochitonium and is characterized by large cataphylls, long oblong to oblongelliptic shaped blades, and red spadix.

It is closest to $A$. apanui Croat, but that species has smaller cataphylls, fewer, more distinct primary veins spaced farther apart, and a green spadix. One specimen from Amazonas, Huashikat 723 , is probably A. tunquii, but it has a longer spadix and cataphylls that are bushier at the base.
This species is named for Santiago Tunqui, who collected many species of Araceae in Amazonas while working on Brent Berlin's anthropological Río Marañón expeditions in Peru.

Paratypes. PERU. AMAZONAS: Río Cenepa, vic. of Huampami, ca. $5 \mathrm{~km} \mathrm{E}$ of Chávez Valdívia, ca. $78^{\circ} 30^{\prime} \mathrm{W}, 4^{\circ} 30^{\prime} \mathrm{S}, 200-$ 250 m, 8 Feb. 1978, Ancuash 1259 (MO); Condor-canqui, El Cenepa, San Antonio, Río Cenepa, 429'30"S, 78¹0’30"W, 300 m, 16 June 1997, Vásquez et al. 24038 (MO).

Anthurium yamayakatense Croat, sp. nov. Type: Perú. Amazonas: Bagua, Yamayakat, 4'55' S, 78¹9' W, 6320 m, Oct. 1995, N. Jaramillo \& S. Katip 788 (holotype, MO05053652, isotype, USM). Fig. 6c.

Planta epiphytica; internodia brevia, 1.2 cm diam. in sicco; cataphylla $7.5-16 \mathrm{~cm}$ longa; petioli $28.5 \mathrm{~cm}$ longi, $5 \mathrm{~mm}$ diam. in sicco; laminae oblongo-ellipticae, $40.5 \mathrm{~cm}$ longae, $11 \mathrm{~cm}$ latae; nervis primariis lateralibus 9 11 utroque. Flores $1.5 \mathrm{~mm}$ longa, $1.7 \mathrm{~mm}$ lata.

Epiphytic; internodes short, drying 1.2 $\mathrm{cm}$ diam.; cataphylls $7.5-16 \mathrm{~cm}$ long, drying brown, lanceolate to almost linear, persisting at upper internodes as a reticulum of fine, pale tan fibers. Petioles $28.5 \mathrm{~cm}$ long, drying $5 \mathrm{~mm}$ diam., yellowish brown, darkened near base; geniculum shaped like petiole, concolorous with petiole, $2 \mathrm{~cm}$ long, drying $4 \mathrm{~mm}$ wide; blades oblong-elliptic, slightly inequilateral, one side up to $5 \mathrm{~mm}$ wider, narrowly acuminate and apiculate at apex, narrowly attenuate at base, $40.5 \times 11 \mathrm{~cm}, 3.7$ times longer than wide, drying light grayish brown, weakly glossy, eglandular above, darker brown, semi-glossy, somewhat inconspicuously glandular-punctate below; midrib narrowly convex, concolorous; primary lateral veins 9-11 per side, $0.8-2$ $\mathrm{cm}$ apart, sometimes arising at an acute angle, then spreading to a $25-40^{\circ}$ angle, prominently loop connected, concolorous, prominulous; collective veins arising from base, equally 
prominent as primary veins, $6-11 \mathrm{~cm}$ from margin. Inflorescence with peduncle $38.5 \mathrm{~cm}$ long, drying $6 \mathrm{~cm}$ wide (flattened), brown slightly tinged with red; spathe reflexedspreading, linear, $12 \mathrm{~cm} \times 11 \mathrm{~mm}, 0.31$ times the length of peduncle, narrowly acuminate and aristate (to $7 \mathrm{~mm}$ ) at apex; spadix cylindrical, abruptly tapering near apex, erect at base, curving to a $90^{\circ}$ angle toward spathe, $17 \mathrm{~cm} \times 6 \mathrm{~mm}$. Flowers $1.5 \times 1.7 \mathrm{~mm}, 7-8$ visible per spiral; lateral tepals $0.8 \mathrm{~mm}$ wide, outside margins 2-sided.

Anthurium yamayakatense is endemic to the type locality in northern Perú at $320 \mathrm{~m}$ in Premontane rain forest (P-rf) life zone. The species is a member of section Porphyrochitonium and is characterized by long cataphylls, elliptic blades, prominulous primary veins, and prominently loopconnected collective veins.

It is similar to A. atamainii, but that species has shorter cataphylls, much more ovate blades, and less prominently loopconnected collective veins.

The species is named for the type locality, the village of Yamayakat in the Province of Bagua, Amazonas Department, Peru.

Dieffenbachia wurdackii Croat, sp. nov. Type: Perú. Loreto: high forest along Río Marañon near Teniente Pinglo, just above Pongo de Manseriche, 300-350 m, 4-7 Oct. 1962, J. Wurdack 2131 (holotype, US2430721; isotypes NY, USM). Fig. 6d.

Planta terrestris; ad $50 \mathrm{~cm}$ alta; internodia 1-26 cm longa, 8-10 cm diam. (in sicco); petioli 13-18 cm longus; vaginati 2/ 3-4/5 per totam longitudinem; lamina elliptica vel oblongo-elliptica, $11.5-18.5 \mathrm{~cm}$ longa, $4.2-7.8 \mathrm{~cm}$ lata, acuta vel rotunda ad basim; nervis primariis lateralis non manifestis; pedunculus $5-9.5 \mathrm{~cm}$ longus; spatha 9.5-14.5 cm longa; spadice 7.8-12.8 cm longus; parte pistillata $3.7-4.5 \mathrm{~cm}$ longus; pistili 18-20; pars staminibus sterilibus 9$11 \mathrm{~mm}$ longa.

Terrestrial or on old tree stumps, to 50 $\mathrm{cm}$ tall; internodes $1-2.6 \mathrm{~cm}$ long, drying 8-
$10 \mathrm{~mm}$ diam., medium yellow-brown to dark yellow-brown, matte, finely striate. Petioles 13-18 cm long, 0.8-1.3 times longer than blade, sheathed $10-12.5 \mathrm{~cm}, 2 / 3-4 / 5$ its length; sheath slender, decurrent to weakly rounded at apex, drying dark yellow-brown, the margins thin, often somewhat undulate; free portion $1.5 \mathrm{~mm}$ diam. at apex; blades elliptic to oblong-elliptic, $11.5-18.5 \times 4.2-$ $7.8 \mathrm{~cm}, 2.2-3.1$ times longer than wide, inequilateral, one side $0.4-0.7 \mathrm{~cm}$ wider, drying greenish yellow-brown above, slightly paler and yellow-green below, gradually acuminate at apex, slightly inequilateral, acute to rounded at apex; midrib drying weakly flatraised and finely striate, slightly paler above, flat, moderately paler and sparcely low-acutestriate below; primary lateral veins not obvious on either surface; minor veins close, fine, arising from midrib at $30-40^{\circ}$ angle. Inflorescences solitary; peduncle $5-9.5 \mathrm{~cm}$ long, drying 3-4 mm diam, medium-dark yellow-brown; spathe $9.5-14.5 \mathrm{~cm}$ long, drying $1.2-1.8 \mathrm{~cm}$ wide, scarcely constricted above, drying yellowish brown; spadix 7.8$12.8 \mathrm{~cm}$ long, pistillate spadix $3.7-4.5 \mathrm{~cm}$ long, pistils 18-20, moderately well-spaced, no more than 3 across the width of the spadix; sterile portion 9-11 mm long; fertile staminate portion $4.0-5.0 \mathrm{~cm}$ long; berries orange, globose, 6-7 $\mathrm{mm}$ diam.

Local Aguaruna name: shikapach sagkap.

Dieffenbachia wurdackii is endemic to Perú, known from Amazonas, Madre de Dios and Loreto Departments at 200-350 m in Tropical moist forest (T-mf) life zone. The species is recognized by its small stature, petioles about as long as blades and sheathed 2/3-4/5 their length, and especially by the more or less elliptic blades with no primary lateral veins.

The species has no clear relatives.

Dieffenbachia wurdackii is named in honor of the late John Wurdack, whose career included work at both the New York Botanical Garden and the Smithsonian Institution. He was perhaps the first to collect in the Río Santiago region and collected the type specimen of this species. 

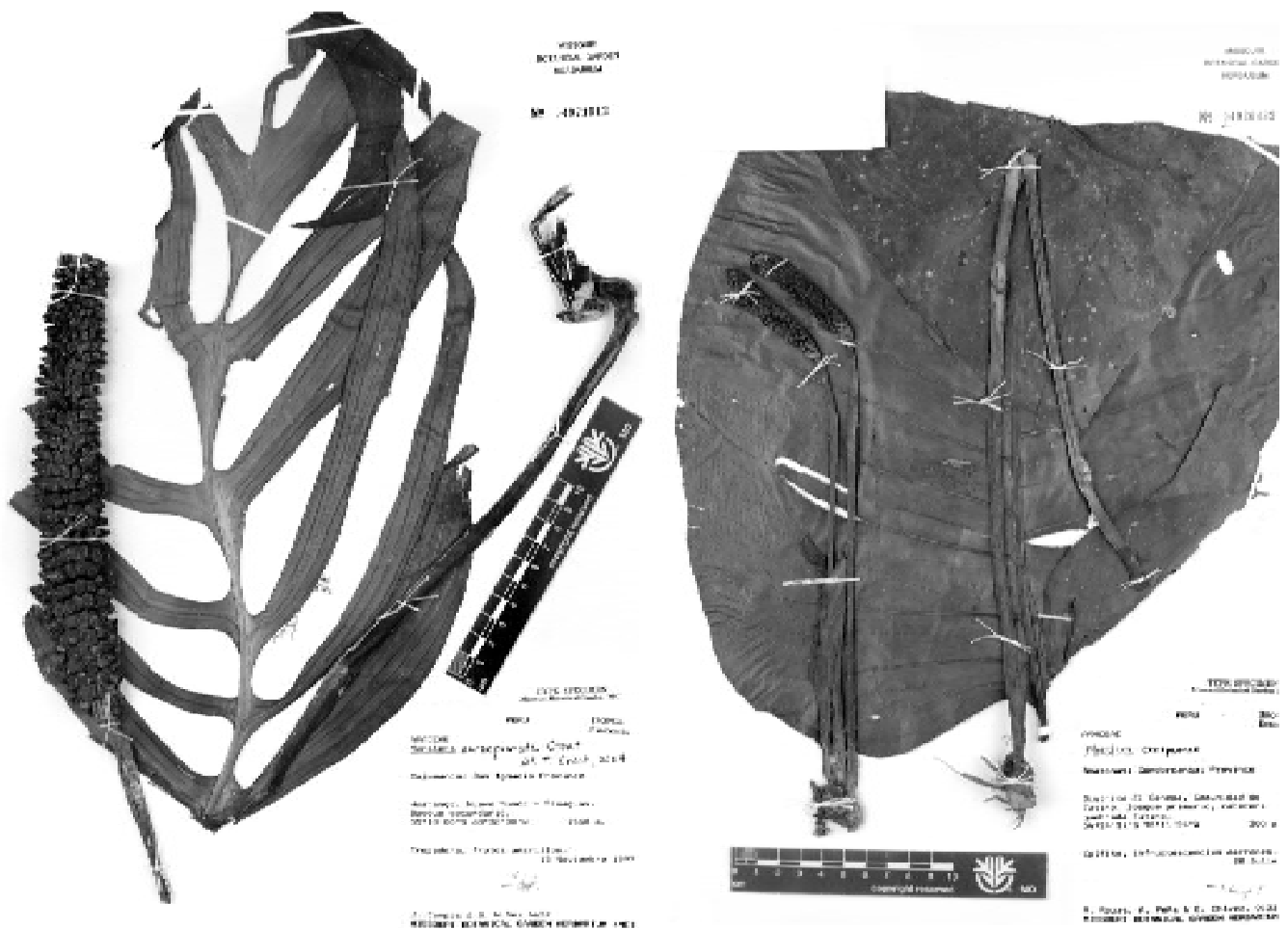

a

b
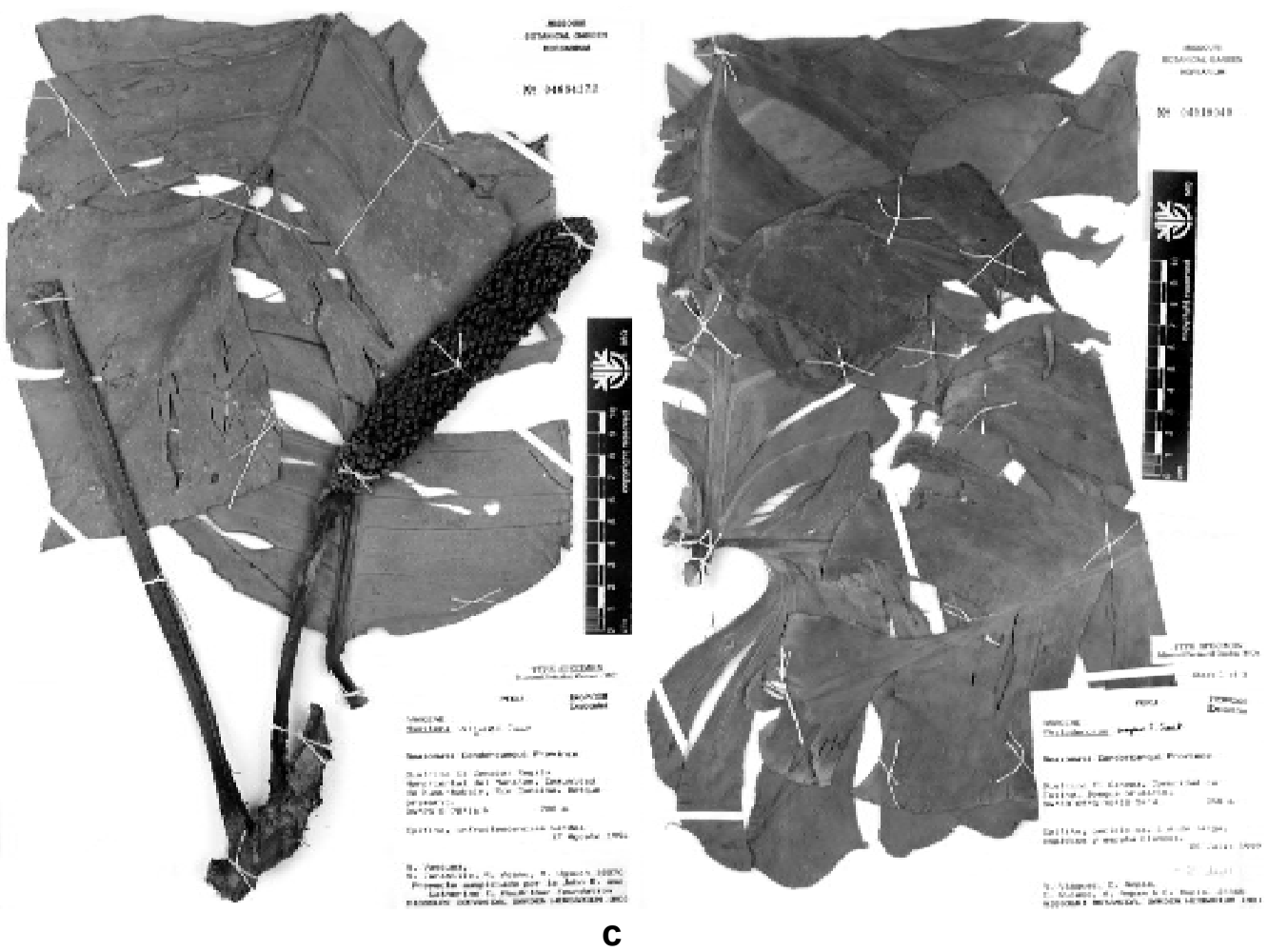

Figure 7 - a. Monstera aureopinnata Croat. Type specimen. (Campos \& Nuñez 4639); b. Monstera cenepensis Croat. Type specimen. (Rojas et al. 0133); c. Monstera vasquezii Croat. Type specimen. (Vasquez et al. 18870); d. Philodendron ampamii Croat. Type specimen. (Vasquez et al. 24488) 
Paratypes: PERU. AMAZONAS: Huambisa, Río Santiago, ca. $65 \mathrm{~km} \mathrm{~N}$ of Pinglo, Caterpiza, 200 m, 6 Feb. 1980, Huashikat 1971 (MO). Madre de Dios: Tambopata, 26 May 1986, Funk et al. 8211 (US).

Monstera aureopinnata Croat, sp. nov. Type: Perú. Amazonas: Cajamarca, San Ignacio, Huarango, Nuevo Mundo-Pisaguas, secondary forest, $5^{\circ} 10^{\prime} 00^{\prime \prime} \mathrm{S}, 68^{\circ} 32^{\prime} 00^{\prime \prime} \mathrm{W}, 13$ Nov. 1997, J. Campos \& S. Nuñez 4639 (holotype, MO-04971512; isotypes, F, K, US, USM). Fig. 7a.

Planta hemiepiphytica; internodia brevia, 2-2.5 cm diam.; petioli 29-44 cm longi; laminae pinnatipartitae, flavida (in sicco); pinnae 3-6 utroque, 1-7.1 cm latae; pedunculus 7.5-9 cm longus; spatha 12-22 cm longa; spadice aurantiacus, $9.5-15 \mathrm{~cm}$ longus.

Appressed-climbing hemiepiphytic; internodes shorter than broad on adult plants, to $2-2.5 \mathrm{~cm}$ diam., longer than broad and to 3 $\mathrm{cm}$ long on preadult plants, epidermis drying yellow-brown, semiglossy, conspicuously longitudinally folded-ridged and transversely fissured. Leaves erect-spreading with petioles thicker than broad, 29-44 cm long, drying finely ribbed, $6-8 \mathrm{~mm}$ thick on free portion, sulcate adaxially, greenish gray, grayish brown to dark yellow-brown, sheathed 13-26 $\mathrm{cm}, 0.36-0.78 \%$ its length; sheath persistent intact; geniculum $2.5 \mathrm{~cm}$ long, drying darker than the petiole; blades pinnately lobed, usually unevenly with an unequal number of pinnae or pinnae of much different widths, 44-58 × 19-26(40) cm, (1.4)2-2.6 times longer than wide, 1.3-1.9 times longer than petioles, drying gray to gray-green to yellowbrown above, usually pale to medium yellowbrown below, less frequently dark yellowbrown below; pinnae 3-6 pairs, $1-7.1 \mathrm{~cm}$ wide, the middle of the lobe 1.2 times wider than the constricted portion, broadly decurrent at base both up and down the rachis, the broadest portion of the pinnae always the very base (as measured from the 2 decurrent sides) this being up to twice the width of the broadest part of any portion distally; the lowermost pinnae sometimes bifurcated to near the base; primary lateral veins $1-4$ per pinnae, drying concolorous to slightly paler and weakly sunken above, narrowly raised and paler below; upper surface weakly and minutely granular, with major veins drying slightly paler, flat or weakly sunken; lower surface drying with minor veins, mostly closely parallel, with occasional oblique interconnectivity (especially toward margins), raphide cells clearly visible as raised lines between the minor veins with occasional short white linear cellular inclusions visible, weakly granular on high magnification. Inflorescence arising in clusters of up to 3; peduncles 7.5$9 \mathrm{~cm}$ long, drying 5-7 mm wide, dark to light yellow-brown, matte, finely striate; spathe 12-22 cm long, 1.4-2 times longer than spadix, drying yellow-brown to dark reddish brown; spadix yellow-orange (post-anthesis) 9.5-15 cm long; pistils ca. $3 \mathrm{~mm}$ long, drying with the ovary ca. $1 \mathrm{~mm}$ wide, the style 1.5 $\mathrm{mm}$ diam., dark brown, minutely papillategranular, matte, acute with the stigma borne at the apex and slightly wider than the dried style; stigma $0.6 \times 0.3 \mathrm{~mm}$, depressed medially with pale brown raised margin; stamens free, ca. $2 \mathrm{~mm}$ long on drying, the thecae $1.2 \mathrm{~mm}$ long, oblong, closely parallel, the filament flattened. Infructescence to $21 \times$ $3 \mathrm{~cm}$ on drying; berries obovoid, red to orange, acutely pointed, to $8 \times 4-5 \mathrm{~mm}$.

Local Aguaruna name: magkamak, katípas. Monstera aureopinnata is known from northeastern Peru, Brazil and Ecuador at 130$1550 \mathrm{~m}$ in Tropical wet forest (T-wf) and Premontane wet forest (P-wf) life zones. The species is characterized by yellowish browndrying, pinnately-lobed leaf blades (hence the epithet 'aureopinnata'), which are lobed to the base with the basal portions of the lobes prominently decurrent in both directions on the rachis. Also characteristic are the acute pistils and the orange to red berries.

Monstera aureopinnata has been confused with M. subpinnata (Schott) Engler and some of the paratypes were so annotated 
by Madison (1977). However, that species has leaf blades that dry blackened and have the pinnae more prominently constricted toward the base (the broadest portion of the pinnae up to 3.7-7.8 times wider than the constricted portion at the base with the total decurrent only $1.5-4 \mathrm{~cm}$ long), and are not so conspicuously decurrent in both directions on the rachis. In contrast, for $M$. aureopinnata the broadest portion of the pinnae is only 1.2 2 times as wide as the narrowest portion, and the total decurrent portion is $3.5-10.3 \mathrm{~cm}$ wide.

A single sterile collection from Brazil in Maranhao, Municipio Monçao along the Río Turiaçu has very similar leaf blades, but that collection dries with the stem dark brown, moderately smooth, and finely striate.

The species is also similar to Schultes \& Cabrera 19325 from Vaupes, Colombia, along the Río Vaupes at Cerro de Tipiaca, but that specimen has pistils truncate at the apex. Paratypes: BRAZIL. AMAZONAS: Río Jurua basin, near mouth of Río Embira (tributary of Río Tarauaca), $7^{\circ} 30^{\prime} \mathrm{S}, 7^{\circ} 15^{\prime} \mathrm{W}$, 10 June 1933, Krukoff 4752 (A). ECUADOR. NAPO: Lago Agrio-Baeza at $\mathrm{km} \mathrm{67.5,}$ $0^{\circ} 01^{\prime} \mathrm{N}, 77^{\circ} 19^{\prime} \mathrm{W}, 1180 \mathrm{~m}, 6$ Oct. 1980 , Croat 50465 (MO). PASTAZA: Finca El Valle de Muerte on Río Curaray, ca. $10 \mathrm{~km}$ E of Curaray (Jesus Pitishka), 200 m, 22 Mar. 1980, Harling 17647 (MO). PERU. San Antonio, Río Samiria. 23 Aug. 1983, Ayala \& Arévalo S. 4229 (MO). AMAZONAS: Yamayakat, Kusu-Chapi, Imaza, Región del Marañon, area permanente $500 \times 500 \mathrm{~m}$, Parcela “'E", 455'S, 78¹9'W, 550 m, Feb. 1995, Vasquez et al. 20066 (MO); 455' S, 78 $8^{\circ} 19^{\prime} \mathrm{W}$, 320 m, 23 Jan. 1996, N. Jaramillo et al. 963 (MO); Río Cenepa, vic. of Huampami, ca. 5 $\mathrm{km}$ E of Chávez Valdívia, 430'S, 78³0'W, 200-250 m, 3 Aug. 1978, Kujikat 148 (MO); $2 \mathrm{~km}$ bajo de La Poza, entrando por la trocha de la isla de La Poza, Río Santiago, 180 m, 16 Aug. 1979, Leveau 166 (MO); Condorcanqui, $\mathrm{S}$ of Huampami trail to house of Theodora, S of Río Cenepa, 240-260 m, 17 July 1974, Berlin 1673 (MO, USM); ridge above
Chikisinuk, a tributary of Huampami, entering from $\mathrm{S}$ about $5 \mathrm{~km}$ from confluence with Río Cenepa, 240-315 m, 21 Dec. 1972, Berlin 665 (MO, USM); Kachaig, 11 June 1973, Ancuash 618 (MO, USM); trail $\mathrm{N}$ of Río Cenepa to Tuhushiku Creek, 215-240 m, 30 July 1974, Berlin 1875 (MO); Bashuchunuk, Huampami, 17 Jan. 1973, Kayap 140 (MO); 1 km behind Caterpiza, E of Quebrada Caterpiza, Río Santiago, 180 m, 24 Nov. 1979, Huashikat 1397 (MO); Cajamarca, San Ignacio, Huarango, Nuevo Mundo-Pisaguas, $5^{\circ} 10^{\prime} 00^{\prime \prime} \mathrm{S}$, 68³2’00"W, 1550 m, 13 Nov. 1997, Campos \& Nuñez 4639 (MO). LORETO: $17 \mathrm{~km}$ SE of Iquitos; 25 July 1972, Croat 18483 (MO); Tigre, Río Corriente, Forestales (Shiviyacu), 25 Nov. 1979, Ayala 2370 (MO); Alto Amazonas, Andoas, Río Pastaza near Ecuador border, 230 m, 17 Nov. 1979, Gentry \& Diaz 28256 (MO); Maynas, Guarnición "Pijuayal", una hora de camino, trocha hacia la parte porterior del Cuartel Militar, $130 \mathrm{~m}$, 7 Sep. 1978, Díaz et al. 547 (MO); Iquitos, Aucaya, 130 m, 7 May 1973, Rimachi 308 (MO); Carretera de Zungaro Cocha a la qurbrada de Shushuna, 120 m, 5 Dec. 1985, Rimachi 8131 (MO); Allpahuayo, Est. Exp. Instituto de Investigaciones de la Amazonía Peruana (IIAP), transect 4, $120 \mathrm{~m}, 2$ June 1990, Vásquez \& Jaramillo 14014 (MO); Indiana, $115 \mathrm{~m}, 3^{\circ} 30^{\prime} \mathrm{S}, 72^{\circ} 58^{\prime} \mathrm{W}, 16 \mathrm{Dec} .1987$, Vásquez \& Jaramillo 10160 (MO); Allpahuayo, Est. Exp. del Instituto de Investigaciones de la Amazonia peruana (IIAP), $4^{\circ} 10^{\prime} \mathrm{S}, 7^{\circ} 30^{\prime} \mathrm{W}, 150-180 \mathrm{~m}, 21$ May 1991, Vasquez et al. 16235 (F, KYO, MO, NY); vic. of Iquitos, collection data lost, 120 m, 1977, Revilla 3676 (MO); Pacaya-Samiria, Res. Nac. Pacaya-Samiria, Est. Biol. Pithecia, Río Samiria, $3^{\circ} 18^{\prime} \mathrm{S}, 74^{\circ} 50^{\prime} \mathrm{W}, 130 \mathrm{~m}, 21$ Oct. 1990, Grández \& Jaramillo 2018 (MO); Requena, Saquena, Río Ucayali, trail from Quebrada de Aucayacu, above Genaro Herrera, 9 Feb. 1979, Rimachi 4278 (MO). SAN MARTÍN: Tingo María, 625-1100 m, 30 Oct.-19 Feb. 1950, Allard 21633 (US); 22436 (US); Mariscal Caceres; 650 m, Tocache Nuevo, Río de la Plata, cerca a la 
Chacra del Sr. Esteban Arévalo, 14 Sep. 1980, Schunke-Vigo 12284 (MO); Pebas, Quebrada Shishita, $10 \mathrm{~km}$ de Pebas, 14 May 1976, Revilla 606 (MO); hills above Chazuta, ridge to W of Chazuta, $6^{\circ} 34^{\prime} \mathrm{S}, 76^{\circ} 12^{\prime} \mathrm{W}, 200-300$ m, 21 Sep. 1986, Knapp 8358 (MO, USM); Río Huallaga basin, 150-350 m, Balsapuerto, 28-30 Aug. 1929, Killip \& Smith 28421 (US).

Monstera cenepensis Croat, sp. nov. Type: Peru. Amazonas: Condorcanqui, El Cenepa, Tutino, headwaters of Tutino, 434'31"S, 7811'34"W, 300 m, 22 July 1997, R. Rojas, A. Peña \& E. Chávez 133 (holotype, MO04920432; isotypes, K, USM). Fig. 7 b.

Planta hemiepiphytica; internodia, brevia, $1.2 \mathrm{~cm}$ diam.; petioli $48 \mathrm{~cm}$ longi, 6-7 mm diam. in sicco; laminae ovatae, $43.5 \mathrm{~cm}$ longae, $18.5 \mathrm{~cm}$ lata, infime subcordata; nervis primariis 12 utroque; pedunculus 19.5 $20 \mathrm{~cm}$ longus; spadice 5.6-6 cm longus, 10 $12 \mathrm{~mm}$ diam.

Hemiepiphytic; internodes short, 1.2 $\mathrm{cm}$ diam., drying blackened, matte, conspicuously warty. Petioles $48 \mathrm{~cm}$ long, drying 6-7 $\mathrm{mm}$ diam., 1.1 times longer than the blade, narrowly flattened adaxially with marginal ribs, becoming obtusely sulcate toward the apex, obtusely ribbed around the circumference, dark brown toward the base, in part pale yellow-brown, sheathed $7.5 \mathrm{~cm}$ long at base; geniculum $3 \mathrm{~cm} \times 5 \mathrm{~mm}$, drying blackened; blades ovate, $43.5 \times 18.5 \mathrm{~cm}, 1.5$ times longer than wide, semiglossy, drying thinly coriaceous, blackened above, dark brown below, inequilateral and acute at apex, weakly subcordate and inequilaterally weakly attenuate at base, inequilateral, one side 1.5 times wider; midrib weakly raised and slightly darker above, thicker than broad, obtusely several-ribbed, minutely granular, slightly darker than the surface; primary lateral veins 12 per side, arising at an acute angle then spreading at $30-50^{\circ}$ angle in upper half of the blade, $70-85^{\circ}$ toward the base, convex and concolorous above, convex and paler below; minor veins arising from both the midrib and the primary lateral veins, becoming subparallel and mostly unbranched in the proximal $1 / 2$ of the blade, but with frequent branching toward margins, very weakly raised and concolorous on lower surface; sinus shallow, ca. $2.5 \mathrm{~cm}$ deep, broadly arcuate. Inflorescence with peduncles 19.5-20 cm long, drying dark yellow-brown, matte; prophyll $11 \mathrm{~cm}$ long, drying dark brown; spathe not seen, spadix $5.6-6 \mathrm{~cm} \times$ 10-12 mm; pistils $1.6-2 \mathrm{~mm}$ long, less than $1 \mathrm{~mm}$ diam.; style dark brown-black, matte, densely papillate, ellipsoid to subrounded 2.8$3.2 \times 2.6-3.0 \mathrm{~mm}$; stigma $2.2-2.4 \times 0.2-0.3$ $\mathrm{mm}$, the margins raised and pale brown; stamens $1.4 \mathrm{~mm}$ long, thecae $0.4 \mathrm{~mm}$ wide. Infructescence brown.

Monstera cenepensis is known only from the type locality in the Río Cenepa region (hence the epithet "cenepense") at $300 \mathrm{~m}$ in the Premontane wet forest (P-wf) life zone.

The species is perhaps most closely related to $M$. adansonii var. laniata, but that species has shorter, thicker peduncles that are proportionately much shorter than those of $M$. cenepensis. In addition, the leaf blades of $M$. adansonii var. laniata typically dry much more green. 
Monstera vasquezii Croat, sp. nov. Type: Perú. Amazonas: Condorcanqui, El Cenepa, Kusu-kubaim, Río Conaina, $4^{\circ} 25^{\prime} \mathrm{S}$, 78¹6'W, 17 Aug. 1994, R. Vasquez, R. Apanu, and M. Ugkuch 18870 (holotype, MO04664172). Fig. 7c.

Planta hemiepiphytica; internodia ad 2.5 $\mathrm{cm}$ longa, $1.8 \mathrm{~cm}$ diam. in sicco; petioli 29 $\mathrm{cm}$ longi, 8-9 $\mathrm{mm} \times 5-6 \mathrm{~m}$ lata; laminae anguste ovatae, $56 \mathrm{~cm}$ longae, $26 \mathrm{~cm}$ latae, rotundata ad basim; nervis primariis lateralibus 14 utroque; pedunculus $13 \mathrm{~cm}$ longus; spadice $17 \mathrm{~cm}$ longus, $3.1 \mathrm{~cm}$ latus (in sicco).

Hemiepiphytic climber; internodes to $2.5 \mathrm{~cm}$ long, drying $1.8 \mathrm{~cm}$ diam., epidermis semiglossy, drying medium gray-brown, frequently peeling free, the underlying stem drying blackened, matte, weakly \& closely ribbed. Petioles $29 \mathrm{~cm}$ long, thicker than broad, $8-9 \mathrm{~mm}$ thick, to $1 \mathrm{~cm}$ wide at the base, 5-6 $\mathrm{mm}$ wide toward the apex, drying matte, gray-brown, narrowly sulcate adaxially with the margins raised, sheathed throughout most of its length, the margin promptly deciduous with a few brown fibers persisting; blades entire, narrowly ovate, $56 \times 26 \mathrm{~cm}, 2.1 \mathrm{~cm}$ longer than wide, acuminate at apex, rounded at base, yellowish gray-green above and below; midrib broadly raised and weakly paler above, narrowly rounded and paler below, drying yellow-brown, matte; primary lateral veins 14 per side, arising at an acute angle, then spreading at $70-85^{\circ}$ angle, drying flattened and darker than surface, finely and minutely ridged; minor veins reticulate throughout the region between the midrib and the margin but moderately obscure on lower surface. Inflorescence solitary; peduncle 13 $\mathrm{cm}$ long, drying blackened, $6 \mathrm{~mm}$ diam.; spadix $17 \mathrm{~cm}$ long, drying $3.1 \mathrm{~cm}$ wide; pistil $1.2 \times 2.2-2.5 \mathrm{~mm}$; stigma $3.2-3.6 \times 3.8-3.0$ $\mathrm{mm}$, dark brown, matte, irregularly oblong to rounded or hexagonal; stigma oblong, 3-3.4 $\mathrm{mm}$ long, $1 \mathrm{~mm}$ wide, deeply sunken medially with a brown raised rim.

Monstera vasquezii is known only from the Río Cenepa region at $700 \mathrm{~m}$ in Premontane wet forest (P-wf) life zone. The species is a member of section Monstera, most closely related to M. dubia because of similar blade shape and drying color. Monstera dubia differs in having a more or less subcordate blade base and conspicuously reticulate tertiary veins. In contrast, $M$. vasquezii has merely rounded blades at the base, and much less conspicuous reticulate venation. In addition, $M$. dubia typically has 1-2 rows of perforations on both sides of the midrib, whereas M. vasquezii is not obviously perforate.

The species is named after Rodolfo Vasquez, Missouri Botanical Garden, preeminent Peruvian botanist and the collector of the type specimen.

Philodendron ampamii Croat, sp. nov. Type: Perú. Amazonas: Condorcanqui, El Cenepa, Tutino, 4³3'05'S, 78¹2'54"W, 28 July 1997, R. Vasquez, D. Amam, E. Quiaco, A. Ampam \& C. Dupis 24488 (holotype, MO04919049; isotypes K, US, USM). Figs. 7d, $8 \mathrm{a}$.

Planta epiphytica; internodia brevia, 3.5 $\mathrm{cm}$ diam. in sicco; petioli ca. $1 \mathrm{~m}$ longi; laminae profunde 3-lobatae, $72 \mathrm{~cm}$ longae, $75 \mathrm{~cm}$ latae; lobus medius $51.5-57.5 \mathrm{~cm}$ longus, $30-40 \mathrm{~cm}$ latus; lobas posterioribus 32-41 cm longus, 17.5-26 cm latus; nervis primariis lateralibus 5-7 utroque. Inflorescentia 5 in quoque axilo; pedunculus $5-8.5 \mathrm{~cm}$ longus, $3 \mathrm{~mm}$ diam. in sicco; spatha alba, 12.5-17.5 cm longa, 2-3 cm diam. in sicco; spadice $15.6 \mathrm{~cm}$ longus; parte pistillata $7.2 \mathrm{~cm}$ longa; parte staminata $8.6 \mathrm{~cm}$ longa.

Large, epiphytic; internodes short, drying $3.5 \mathrm{~cm}$ diam., yellow-brown, coarsely and irregularly acute-ridged; cataphylls not seen, but promptly deciduous. Petioles to ca. $1 \mathrm{~m}$ long, subterete near apex, drying narrowly and deeply sulcate toward the based, broadly flattened near the base, finely to coarsely ribbed abaxially, drying dark reddish brown, matte; blades deeply 3-lobed, $72 \times$ $75 \mathrm{~cm}$, subcoriaceous, drying dark yellowish gray-brown above, paler and 
reddish brown below; medial lobe 51.5-57.5 $\times 30-40 \mathrm{~cm}$; posterior lobes $32-41 \times 17.5-$ $26 \mathrm{~cm}$, spreading laterally, the lower margin straight or prominently sinuate; basal veins 18 pairs, the 1 st pair free to the base, the remaining variously united into a posterior rib which extend straight to the tip of the blade, 11-12 veins basioscopic, 7 acroscopic; midrib broadly convex and slightly paler above, more nearly convex and finely ribbed below, drying yellow-brown and paler than the surface; primary lateral veins 5-7 per side, arising at $60-70^{\circ}$ angle; minor veins drying weakly raised, concolorous, arising from both the midrib and the primary lateral veins. Inflorescence 5 per axil, white, drying dark red-brown; peduncle $5-8.5 \mathrm{~cm}$ long, drying flattened, $3 \mathrm{~mm}$ diam., finely ridged; spathe white, $12.5-17.5 \times 2-3 \mathrm{~cm}$ on drying, matte, minutely granuliform and covered sparsely with minute white globular protrusions (not capable of being scraped free without disintegrating); spadix $15.6 \mathrm{~cm}$ long; pistillate portion $7.2 \mathrm{~cm}$ long; staminate portion $8.6 \mathrm{~cm}$ long; pistils $2 \times 1 \mathrm{~mm}$ on drying; style $1.2 \mathrm{~mm}$ diam., drying pale brown; 0.8-0.9 mm diam.; locules 5; ovules 1 per locule.

Philodendron ampamii is known only from Amazonas, Peru at ca. 340 m elevation, and occurs in the Premontane wet forest (Pwf) life zone.

This new species is characterized by deeply 3-lobed blades that are dark brown on the upper surface and dark yellow-brown on the lower surface with major veins convex on the lower surface. The spathe is white and the peduncles dry slender and blackened. It is closely related to $P$. brent-berlinii Croat, which shares similarly deeply 3 -lobed blades with prominent lateral auricles. Philodendron brent-berliniii differs in having blades that dry yellowish gray on both surfaces and major veins that dry bluntly acute on the lower surface. Philodendron brent-berlinii also differs in having the spathe tinged orange or reddish brown with the peduncles thicker. 

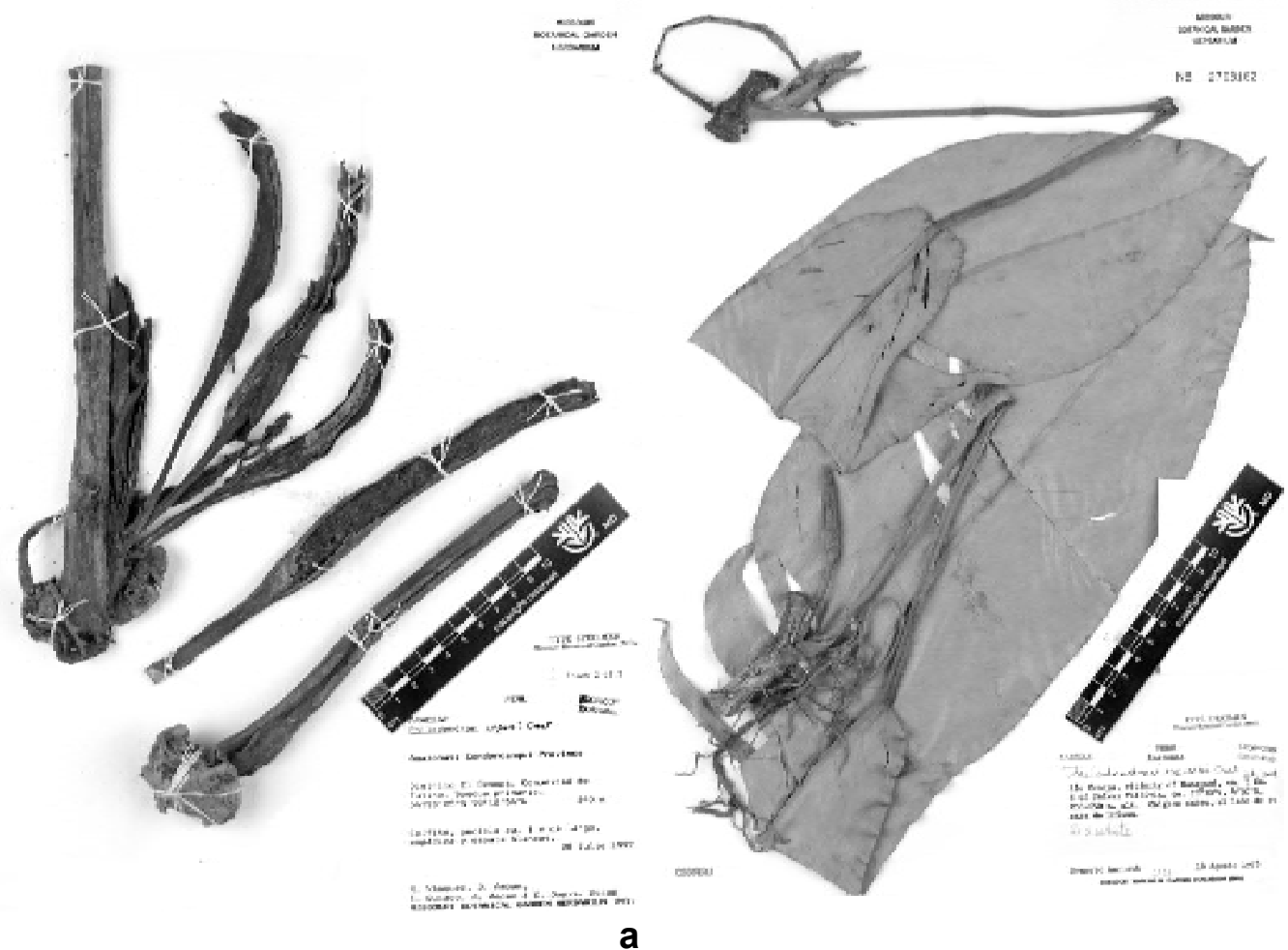

a

b

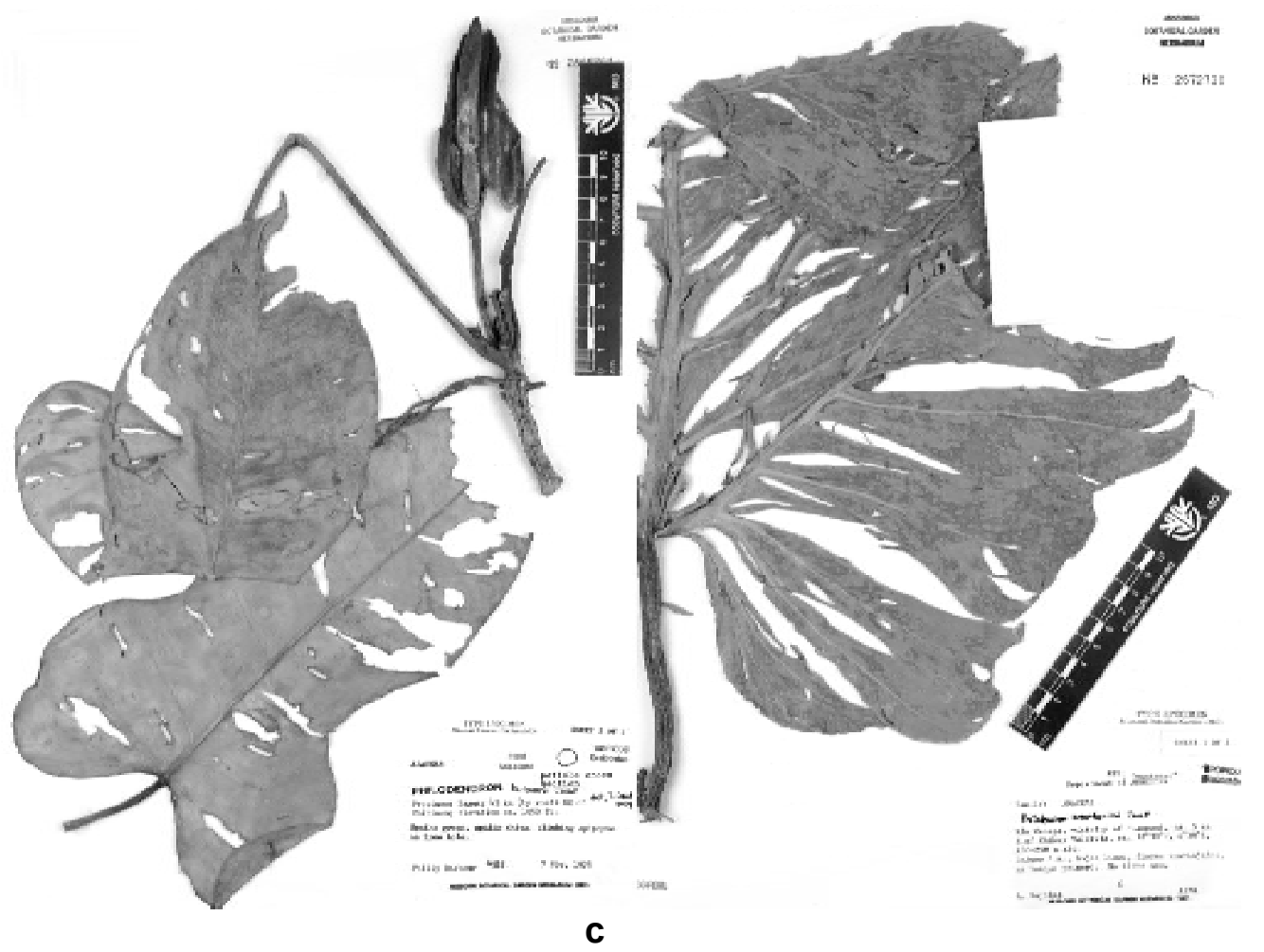

Figure 8 - a. Philodendron ampamii Croat. Type specimen. (Vasquez et al. 24488); b. Philodendron ancuashii Croat. Type specimen. (Ancuash 1463); c. Philodendron barbourii Croat. Type specimen. (Barbour 4511); d. Philodendron brent-berlinii Croat. Type specimen. (Kujikat 6 ) 
Philodendron ancuashii Croat, sp. nov. Type: Perú. Amazonas: Río Cenepa, vic. Hampami, ca. $5 \mathrm{~km}$ E of Chávez Valdivia, ca. 4³0'S, 78³0'W, 200-250 m, 14 Aug. 1978, E. Ancuash 1463 (holotype, MO-2708162). Fig. 8b.

Planta hemiepiphytica; internodia ad 2 $\mathrm{cm}$ longa, $1.5 \mathrm{~mm}$ diam; petioli $32-32.5 \mathrm{~cm}$ longi, 4-5 mm diam.; laminae oblongolanceolatae 37.5-46.5 cm longae, 11.8-16.5 cm latae, nervis primariis debilis, 4 utroque; inflorescentia 2 in quoque axila; pedunculus 3.5-4.5 cm longus, $2.5 \mathrm{~mm}$ diam.; spatha 4.4$4.6 \mathrm{~cm}$ longa, 4-5 mm diam; spadice $3.8 \mathrm{~cm}$ longus; parte pistillata $1.7 \mathrm{~cm}$ longa, $1.1 \mathrm{~mm}$ diam.

Hemiepiphytic plant; internodes to $2 \mathrm{~cm}$ or more long, to $1.5 \mathrm{~cm}$ diam., drying deeply folded, light reddish brown, the surface smooth or sometimes closely transversefissured; cataphylls not seen. Petioles 32$32.5 \mathrm{~cm} \times 4-5 \mathrm{~mm}$, drying somewhat flattened throughout, obtusely sulcate toward the base and toward the apex, medium reddish brown, irregularly and minutely sulcate-ribbed throughout, matte; blades oblongoblanceolate, $37.5-46.5 \times 11.8-16.5 \mathrm{~cm}, 3.1-$ 3.8 times longer than wide, abruptly acuminate at apex, narrowly rounded at base, drying gray above, faintly reddish brown below; midrib drying obtusely sunken to weakly raised and +/-concolorous above; primary lateral veins 4 per side, drying not at all apparent above, weakly visible, but scarcely raised below, arising at an acute angle then spreading at $55-60^{\circ}$ angle; minor veins drying quilted-sunken and concolorous above, close and moderately fine, distinctly visible, much less apparent below, scarcely raised, concolorous. Inflorescences 2 per axil; peduncle $3.5-4.5 \mathrm{~cm}$ long, drying pale reddish brown, finely ridged, $2.5 \mathrm{~mm}$ diam.; spathe $4.4-4.6 \mathrm{~cm} \times 4-5 \mathrm{~mm}$, finely ridged externally; spadix $3.8 \mathrm{~cm}$ long; pistillate portion $1.7 \mathrm{~cm} \times 1.1 \mathrm{~mm}$ throughout; staminate portion $2.1 \mathrm{~cm}$ long, the sterile staminate flower in a single whorl; pistils 4 6-sided or subcircular at apex, $4 \mathrm{~mm}$ diam. except for those at the apex and base to $6 \mathrm{~mm}$ diam., the outer margin pale brown, the center dark brown; locules 3 , one basal ovule per locule; ovules $0.2 \mathrm{~mm}$ long, densely papillate, white.

Philodendron ancuashii is known only from the type locality near Huampami along the Río Cenepa at 200-250 m elevation in Tropical wet forest (T-wf) and Premontane wet forest $(\mathrm{P}-\mathrm{wf})$ life zones.

The species is most similar to $P$. herthae K. Kr. or P. uleanum Engl., but differs from both by the lack of primary lateral veins on the upper blade surface and by the tiny inflorescences. Philodendron ancuashii is a member of Philodendron subgenus Philodendron, section Baursia, in part characterized by the general lack of primary lateral veins. Both $P$. herthae and $P$. uleanum are members of section Philodendron series Glossophyllum Croat.

The species is named in honor of Ernesto Ancuash, an Aguaruna plant collector who collected the type specimen as part of Brent Berlin's ethnobotanical research expeditions to the Alto Marañón river region.

Philodendron avenium Grayum \& Croat, sp. nov. Type: Perú. Amazonas: Río Santiago valley, Huambisa, $65 \mathrm{~km} \mathrm{~N}$ of Pinglo, 2-3 km behind Caterpiza, 200 m, 8 Feb. 1980, $V$. Huashikat 2016 (holotype, MO-2828537). Fig. 9d.

Planta hemiepiphytica; internodia 3.5$6 \mathrm{~cm}$ longa, 4-5 mm diam.; petioli 7-8 cm longi, 7.4-7.5 mm lati; laminae oblongoellipticae, $21.2-21.8 \mathrm{~cm}$ longae, $2.6-2.9 \mathrm{~cm}$ latae; nervis primariis lateralibus obscuris; pedunculus $5.5 \mathrm{~cm}$ longus; spatha $7.5-10 \mathrm{~cm}$ longa, $1.8 \mathrm{~cm}$ diam., viridis extus, pallide viridis intus; spadice $8.7 \mathrm{~cm}$ longus; parte pistillata $2.5 \mathrm{~cm}$ longa, $1.0 \mathrm{~cm}$ diam.

Hemiepiphytic vine; internodes 3.5-6 cm long, drying 4-5 mm diam., coarsely and irregularly ridged longitudinally, pale yellowbrown, semiglossy, the epidermis otherwise smooth. Petioles 7-8 $\times 7.4-7.5 \mathrm{~cm}$, sheathed to within $8 \mathrm{~mm}$ from base of blade; sheath 

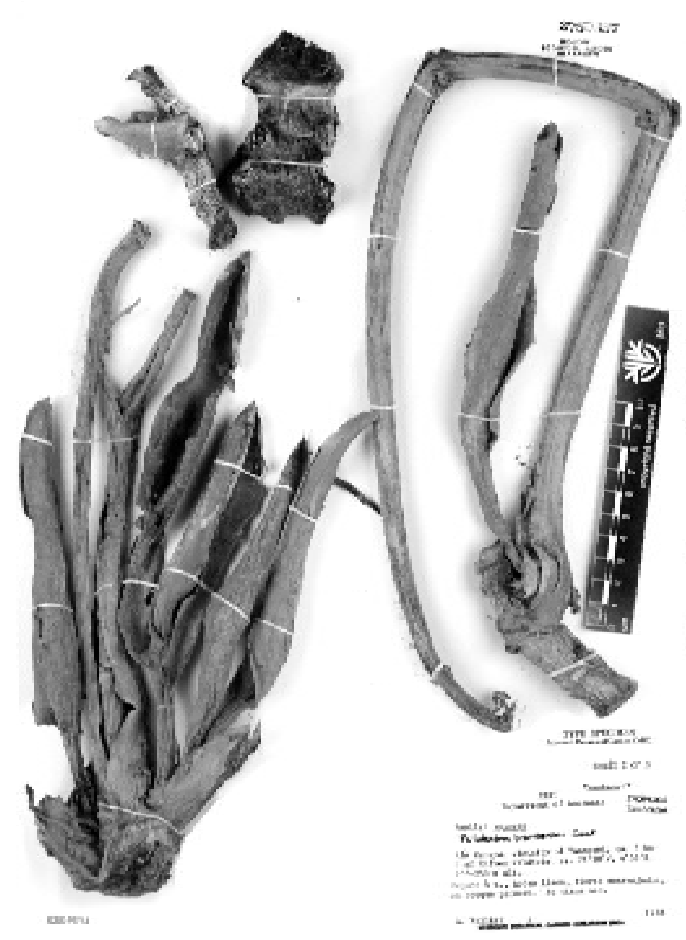

a

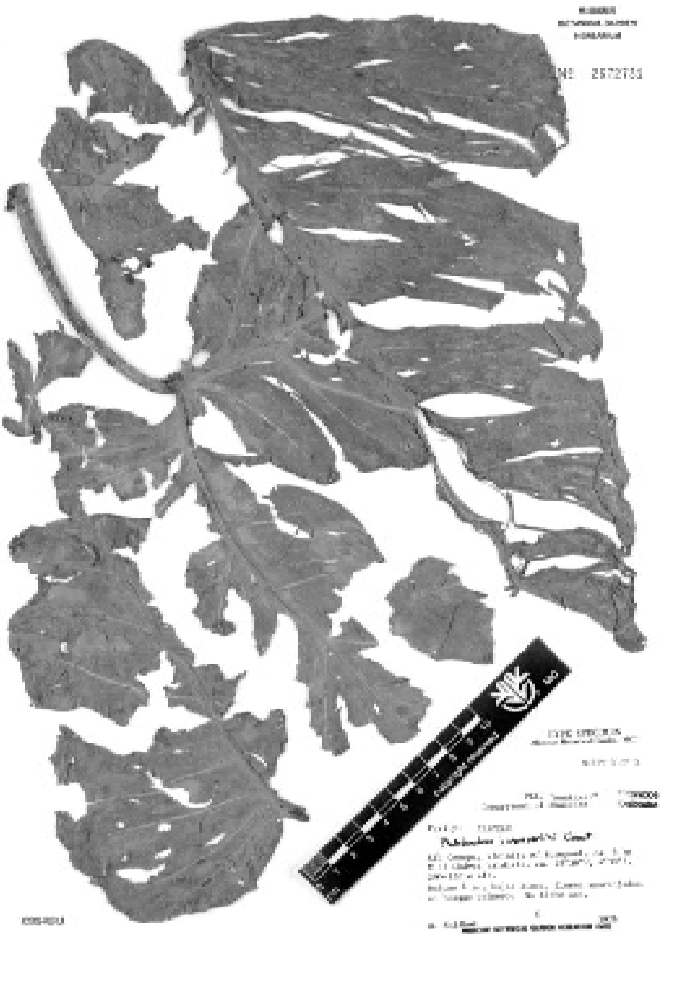

b

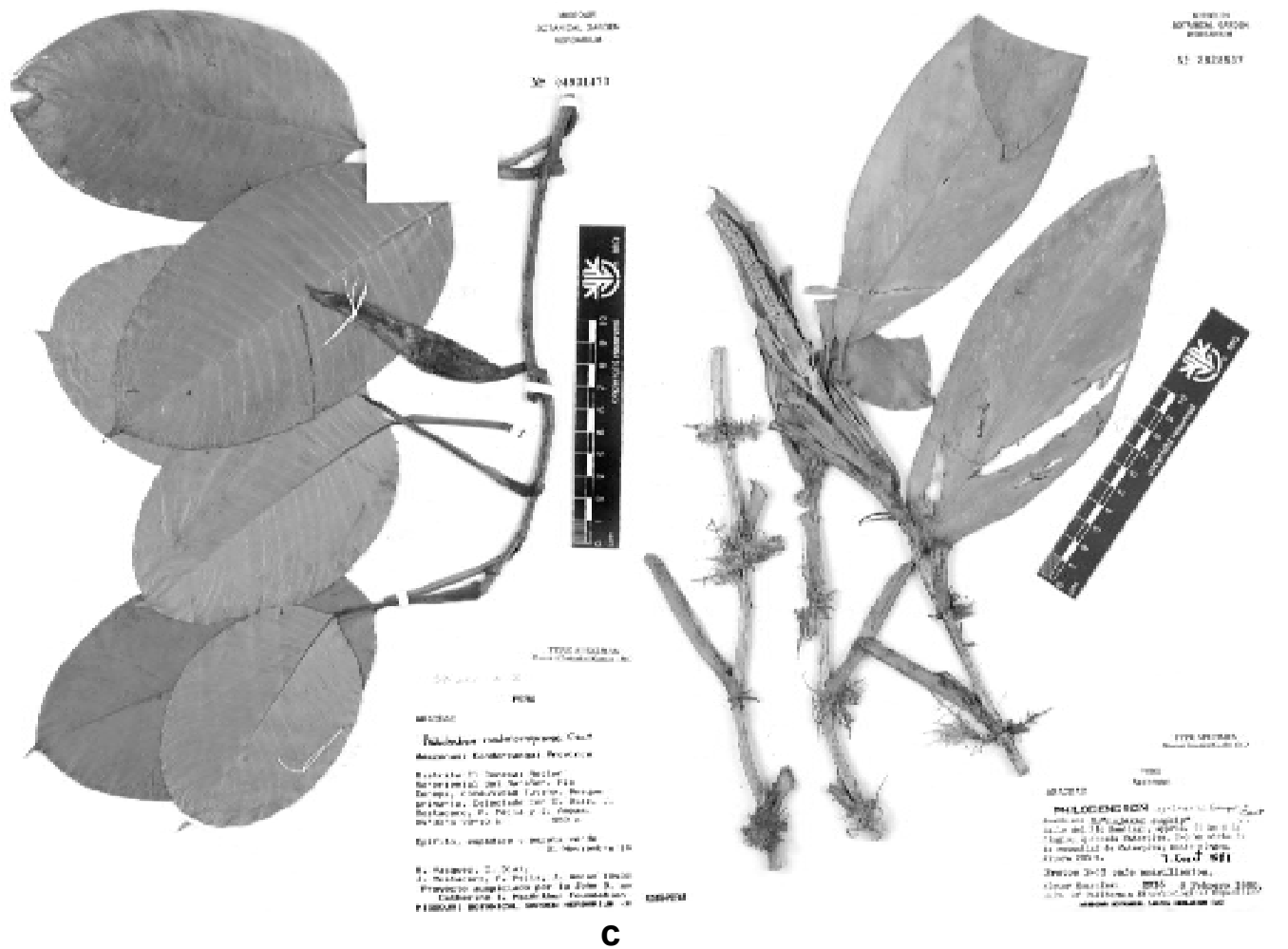

Figure 9 - a, b. Philodendron brent-berlinii Croat. Type specimen. (Kujikat 6); c. Philodendron codorcanquense Croat. Type specimen. (Vasquez et al. 18438); d. Philodendron avenium Grayum \& Croat. Type specimen. (Huashikat 2016)

Rodriguésia 56 (88): 65-126. 2005 
$5.5-7.4 \mathrm{~cm} \times 5-7 \mathrm{~mm}$ on each side, held erect, along with the shaft of the petiole finely ribbed on drying, yellowish brown; free part of petiole sharply and narrowly sulcate on drying; blades oblong-elliptic, 21.2-21.8 $\times$ $7.5 \mathrm{~cm}, 2.6-2.9$ times longer than wide, 3.1 times longer than petioles, weakly shortacuminate at apex, narrowly rounded at base, drying gray and matte above, paler and yellowish gray and weakly glossy below; midrib scarcely visible, weakly raised and concolorous above, convex, light yellow brown and finely ridged below; primary lateral veins not at all apparent; minor veins arising at ca. $35^{\circ}$ angle, narrowly and weakly raised above, scarcely raised below, both surfaces finely granular throughout including on the minor veins. Inflorescence solitary; peduncle $5.5 \mathrm{~cm}$ long, drying $3.5 \mathrm{~mm}$ wide, coarsely ridged and densely pale-speckled; spathe $7.5-10 \times 1.8 \mathrm{~cm}$, medium green outside, drying matte, paler green within, drying yellow-brown with prominently raised purplish resin canals extending throughout much of the spathe (to within $2 \mathrm{~cm}$ from tip of spathe); spadix stipitate $3 \mathrm{~mm}$ long on back side, $8.7 \mathrm{~cm}$ long; pistillate spadix $2.5 \times 1.0$ $\mathrm{cm}$, weakly tapered toward the base; staminate spadix drying $6.4 \mathrm{~cm}$ long, sterile portion $1 \times$ $1.1 \mathrm{~cm}$; fertile staminate portion narrowly tapered toward apex, $6 \mathrm{~mm}$ diam.; pistils narrowly tapered to apex, drying $0.5 \mathrm{~mm}$ diam.; style with a broad thin wafer-like apron $1-1.2 \mathrm{~mm}$ wide; stigma donut-shaped, $0.8 \mathrm{~mm}$ diam.

Philodendron avenium is a member of subgenus Pteromischum. It is characterized by finely ridged yellow-brown stems, nearly fully sheathed petioles, and oblong-elliptic, grayish-drying blades that lack obvious primary lateral veins on the dried blades (hence the epithet "avenium" meaning "without veins").

Philodendron avenium is similar to $P$. pteropus Mart. ex Schott because they both have blades less than $10 \mathrm{~cm}$ long and obscure primary lateral veins, however, $P$. avenium has blades with a more or less rounded base and $P$. pteropus has blades that are acute to attenuated at the base. Philodendron avenium is also similar to $P$. caudatum $\mathrm{K}$. Kr. because they both have blades less than $10 \mathrm{~cm}$ long, obscure primary lateral veins, and blades with rounded bases. However, P. caudatum has blades with 5 to 7 moderately prominent primary lateral veins, often drying dark to reddish brown on the lower surface, while $P$. avenium has scarcely apparent primary lateral veins.

Philodendron barbourii Croat, sp. nov. Type: Perú. Amazonas: Bagua, $43 \mathrm{~km} \mathrm{NE}$ of Chiriaco, 1050 m, 7 Nov. 1978, P. Barbour 4511 (holotype, MO-2800701; isotypes, USM). Fig. 8c.

Planta hemiepiphytica; internodia $5 \mathrm{~cm}$ longa, 1-1.5 cm lata; cataphylla 5.2-6 cm longa; petioli 25.5-31.5 cm longi, minus $1 \mathrm{~cm}$ diam.; laminae panduriformi, 26-30 cm longae, 14.5-19.5 cm latae; nervis primariis lateralibus 3-5 utroque; pedunculus $6 \mathrm{~cm}$ longus; spatha $9.5 \mathrm{~cm}$ longa, viridis; spadice $9.5 \mathrm{~cm}$ longus; pars pistillata $2.9 \mathrm{~cm}$ longa, $8.5 \mathrm{~mm}$ diam.

Appressed-climbing hemiepiphytic vine; internodes elongated, more than $5 \mathrm{~cm}$ long, $1-1.5 \mathrm{~cm}$ diam., drying medium yellowbrown, irregularly and sharply ridged on drying, semiglossy; cataphylls $5.2-6 \mathrm{~cm}$ long, green, sharply flattened on one side, deciduous. Petioles 25.5-31.5 cm long, less than $1 \mathrm{~cm}$ diam., equal to or somewhat longer than the blades, terete, drying dark yellowbrown, finely and acutely ribbed, the genicular area drying blackened, 2.5-3 cm long, sheathed $1.0-1.5 \mathrm{~cm}$ at the base; blades panduriforme, $26-30 \times 14.5-19.5 \mathrm{~cm}, 1.5-1.8$ times longer than wide, subcordate with somewhat spreading lobes at base, abruptly acuminate at apex, prominently constricted 8$12 \mathrm{~cm}$ above the base; drying matte and grayish yellow above, somewhat paler and yellow-brown below; anterior lobe 24-25 cm long, the constricted area $6.5-9.5 \mathrm{~cm}$ wide, 9.5-14.7 $\mathrm{cm}$ wide in the broadest area of the anterior lobe above the constriction; posteri- 
or lobes $7.7-10.5 \mathrm{~cm}$ long, directed more or less outward, about as long as broad; sinus 2$4.5 \mathrm{~cm}$ deep, arcuate to parabolic at apex; midrib drying +/- flattened, closely and finely ridged, darker than surface above, narrowly raised, closely and finely acute-ribbed, +/concolorous below; primary lateral veins 3 5 per side, arising at $65-70^{\circ}$ angle; basal veins 3 per side, the $1^{\text {st }}$ pair free to the base, spreading at $80-90^{\circ}$ angle; major veins moderately obscure above, weakly raised and slightly paler below; minor veins moderately distinct, weakly raised below. Inflorescence solitary; peduncle $6 \mathrm{~cm}$ long, drying blackened and finely ridged, $4 \mathrm{~mm}$ wide; spathe $9.5 \mathrm{~cm}$ long, green; spadix $9.5 \mathrm{~cm}$ long; pistillate spadix $2.9 \mathrm{~cm}$ long in front, $2.7 \mathrm{~cm}$ long in back, $8 \mathrm{~mm}$ diam. at base, 8.5 $\mathrm{mm}$ diam. midway, $7 \mathrm{~mm}$ diam. at apex; staminate portion white, $6.5 \mathrm{~cm}$ long; sterile portion $1 \times 0.9 \mathrm{~cm}$; fertile portion $1.1 \mathrm{~cm}$ wide in broadest portion toward the apex, bluntly tapered at the apex; pistil with stigma $0.7-$ $1.0 \mathrm{~mm}$ wide; ovary $1.8 \mathrm{~mm}$ long, 3-4-locular; ovules basal, $0.026 \mathrm{~mm}$ long; funicle 0.014 $\mathrm{mm}$, the ovary borne within a translucent gelatinous envelope $0.08 \mathrm{~mm}$ long.

Philodendron barbourii is known only from the type specimen in Tropical wet forest (T-wf) and Premontane wet forest (P-wf) life zones. The species is characterized by long internodes, hemiepiphytic habit, yellowbrown finely ridged dried stem, petioles about as long as the blades, and especially by the panduriform blades.

Philodendron barbourii might be confused with $P$. panduriforme Schott, but that species has blades that are much broader and dry black. Philodendron barbourii is similar to P. nullinervium E. G. Gonc. from Brazil (Acre) and the western Amazon in having a hemiepihytic habit, long internodes, and panduriform blades. However, $P$. nullinervium has petioles usually longer than the blades (instead of the petioles being closer to the same length as the blades in $P$. barbourii). Also, P. barbourii has much shorter peduncles than $P$. nullinervium, and the spathe in $P$. barbourii is green, while the spathe in $P$. nullinervium is green to whitish pink outside and purple inside.

The species is named in honor of Phillip Barbour from Louisiana, a former student at the Missouri Botanical Garden who collected many Araceae, including the type specimen of this species while on an expedition with ornithologists from Louisiana State University.

Philodendron brent-berlinii Croat, sp. nov. Type: Peru. Amazonas: Río Cenepa, vic. of Huampami, ca. $5 \mathrm{~km}$ E of Chávez Valdívia, ca. $4^{\circ} 30^{\prime} \mathrm{S}, 78^{\circ} 30^{\prime} \mathrm{W}, 200-250 \mathrm{~m}, 3$ Aug. 1978, A. Kujikat 6 (holotype, MO-2672730). Figs. 8d, 9a, b.

Planta hemiepiphytica; internodia brevia, $4.5 \mathrm{~cm}$ diam. in sicco; cataphylla 26 cm longa; petioli $77 \mathrm{~cm}$ longi; laminae profunde 3-lobatae, 46-57 cm longae; lobulus auteriores 36-38 cm longae, 29-36 cm latae; nervis primariis lateralibus 5 utroque; pedunculus, 4-5.5 cm longus; spatha 14.5$16 \mathrm{~cm}$ longa; spadice $13 \mathrm{~cm}$ longus, pars pistillata $5 \mathrm{~cm}$ longa, $1 \mathrm{~cm}$ diam.; ovula 1-2 per loculum.

Hemiepiphytic climber to $4 \mathrm{~m}$, internodes short, drying $4.5 \mathrm{~cm}$ wide, closely and irregularly ridged, forming a reticulum of ridges, reddish brown; cataphylls $26 \mathrm{~cm}$ long, sharply 2-low-ridged, deciduous, drying light reddish brown. Petioles subterete, $77 \mathrm{~cm}$ long, subterete, drying reddish brown, convex to broadly concave abaxially, coarsely 3 ribbed adaxially, finely ridged and warty circumferentially; blades deeply 3-lobed, 46$57 \mathrm{~cm}$ long, drying gray above, reddish brown below; anterior lobe 36-38 × 29-36 cm, acuminate; midrib obtusely raised and slightly paler above, convex, grayish yellowbrown and slightly paler below; primary lateral veins 5 per side, arising at $55-65^{\circ}$ angle, drying broadly convex above with a weak medial sulcus, slightly paler above, broadly convex and paler below, finely striate; minor veins moderately obscure; lower surface finely granular. Inflorescences 3 to 4 per axil; 
peduncle $4-5.5 \mathrm{~cm}$ long, drying pale reddish brown, matte, finely ribbed and densely warty; spathe $14.5-16 \times 2-2.5 \mathrm{~cm}$, drying pale reddish brown, matte; spadix $13 \mathrm{~cm}$ long; pistillate spadix $5 \mathrm{~cm}$ long, $1 \mathrm{~cm}$ diam.; staminate portion $8 \mathrm{~cm}$ long; sterile staminate portion 1 $\times 1.4 \mathrm{~cm}$; fertile staminate portion $8 \times 10-11$ $\mathrm{mm}$ at base, promptly constricting to $8 \times 10 \mathrm{~mm}$ diam. constricted area $1 \mathrm{~cm}$ above the base, then gradually tapered to a pointed apex; locules 5-6; ovules 1-2 per locule, basal, ca. $1 \mathrm{~mm}$ long along with the slender funicle, funicle about as long as the ovule.

Local Aguaruna name: kachi.

Philodendron brent-berlinii is known from the Department of Amazonas, Peru and on Cerro Antisana in Napo Province, Ecuador at $200-440 \mathrm{~m}$ in Tropical wet forest (T-wf) and Premontane wet forest $(\mathrm{P}-\mathrm{wf})$ life zones.

The species is characterized by deeply 3-lobed, yellowish gray-drying blades. It is closely related to $P$. ampamii, which shares similarly deeply 3-lobed blades with prominent lateral auricles. Philodendron ampamii differs in having blades drying dark brown above, dark yellow-brown below with the major veins drying broadly convex on lower surface. In addition, the spathe dries somewhat blackened with slender peduncles. In contrast, $P$. brent-berlinii has blades which dry yellowish gray, major veins, which dry bluntly acute on lower surface and spathes that dry pale reddish brown with thicker peduncles.

Grubb et al. 1601, from Cerro Antisana near Shinquipino at $1450 \mathrm{~m}$ has a petiole 100 $115 \mathrm{~cm}$ long and is said to have white lower flowers with brown tips and pink to pinkish green upper flowers. However, no inflorescences were available for study.

Paratypes: ECUADOR. Cerro Antisana, Shinquipino, 440 m, 13 Sep. 1960, P.J. Grubb et al. $1601(\mathrm{~K})$. PERU. AMAZONAS: Río Santiago valley, ca. $65 \mathrm{~km}$ N Pinglo, 2-3 km behind Caterpiza, 200 m, Huashikat 2297 (MO).
Philodendron condorcanquense Grayum \& Croat, sp. nov. Type: Perú. Amazonas: Condorcanqui, El Cenepa, Río Cenepa, Tutino, 350 m, 21 Nov. 1993, R. Vasquez, C. Diaz, J. Mostacero, F. Mejia, J. Ampam 18438 (holotype, MO-04931473; isotype, USM). Fig. 9c.

Planta hemiepiphytica; internodia 1-4 cm longa, 4-5 mm diam in sicco; petioli 6-cm longi; laminae ellipticae vel ovata-ellipticae, $12 \mathrm{~cm}$ longae, $7.8 \mathrm{~cm}$ latae; nervis primariis lateralibus 13-16 utroque; inflorescentia 1 in quoque axilo; pedunculus $1.5 \mathrm{~cm}$ longus, $5 \mathrm{~mm}$ diam in sicco; spatha $9.5 \mathrm{~cm}$ longa, $1.7 \mathrm{~cm}$ lata in sicco; spadice $8.2 \mathrm{~cm}$ longus; parte pistillata $3.2 \mathrm{~cm}$ longa.

Hemiepiphytic vine; internodes terete, 1-4 cm long, drying 4-5 mm diam., medium yellow-brown, moderately glossy, closely longitudinally folded-ridged with moderately acute edges and with a sparce scattering of dark lenticilate protrusions. Petioles 6-9 cm long, sheathed $3 / 5$ the length, or more commonly, nearly throughout, drying dark yellowish green-brown and finely ribbed outside, yellowish brown inside, sometimes transverse-fissured near the base, the margins sometimes minutely undulate and somewhat scarious near base; blades elliptic or ovateelliptic, ca. $12 \times 7.8 \mathrm{~cm}, 1.5$ times longer than wide, 1.8 times longer than petiole, rounded to obtuse and briefly acuminate to cuspidate at apex, broadly obtuse to rounded and briefly attenuate at base, drying greenish gray above, moderately paler and grayish yellow-green below; midrib weakly sunken and concolorous above, narrowly round-raised, slightly paler below, drying yellow-brown and finely ridged; primary lateral veins 13-16 per side, arising at an acute angle then spreading at $75-80^{\circ}$, drying weakly raised and concolorous above, scarcely more prominent than the interprimary veins above, convex to flat-raised and paler below; minor veins weakly raised and concolorous above, interconnected with cross-veins especially toward the margins above, rather prominently raised and slightly darker below, the smaller 


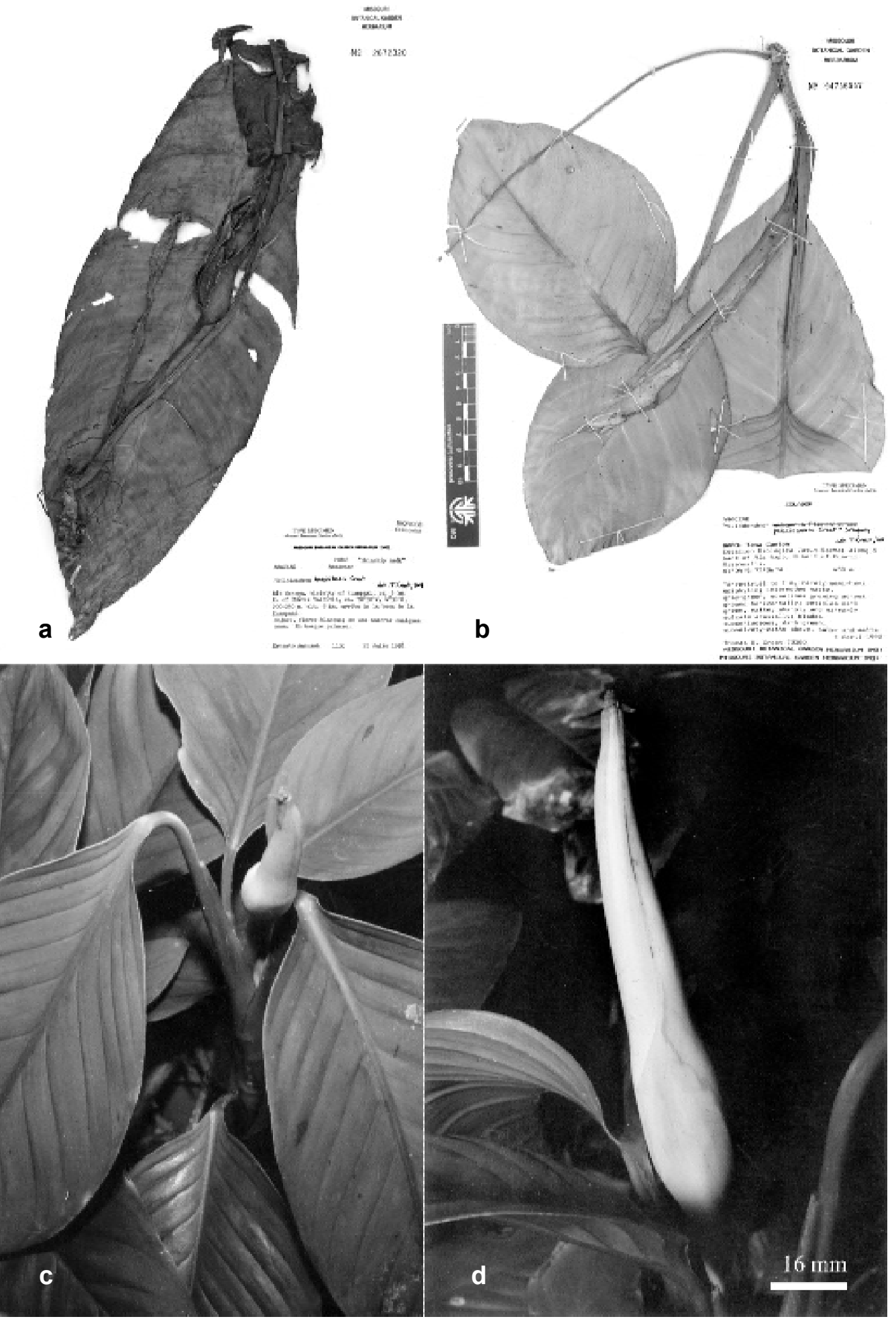

Figure 10 - a. Philodendron huashikatii Type specimen. (Ancuash 1130); b, c, d. Philodendron palaciosii Grayum \& Croat. b. herbarium type specimen (Croat 73380); c. habit, showing leaf blades and inflorescence; d. close-up of inflorescence. c, d. Photos by Tom Croat. 
minor veins interconnecting toward margins or sometimes simply ending with no connection; cross- veins rather prominent toward margins below; areas between veins minutely and densely granular and sparsely white-stitched above, more conspicuously but more sparsely granular with 1-2 irregular rows of white stitching below. Inflorescence 1 per axil; peduncle $1.5 \mathrm{~cm}$ long, drying 5 mm wide; spathe $9.5 \mathrm{~cm}$ long, $1.7 \mathrm{~cm}$ wide on drying, dark brown, finely short palelineate throughout outside, drying dark brown inside with coarsely raised with resin canals inside; spadix $8.2 \mathrm{~cm}$ long; pistillate portion $3.2 \mathrm{~cm} \times 8 \mathrm{~mm}$; staminate portion $5.3 \mathrm{~cm}$ long; sterile staminate portion $8 \times 9 \mathrm{~mm}$; fertile staminate portion $4.5 \mathrm{~cm} \times 7 \mathrm{~mm}$ midway; pistils $1.5 \mathrm{~mm}$ long, the stigma apron drying 7-8 mm wide, light brown, undulate; stigma button-shaped with a deep medial funnel, 4$5 \mathrm{~mm}$ diam., drying dark brown.

Philodendron condorcanquense is known only from the type material. It is a member of subgenus Pteromischium and is characterized by hemiepiphytic scandent habit, closely ridged, yellow brown-drying stems, mostly fully sheathed petioles, and especially by its elliptic blades which dry grayish yellow-green below and have conspicuous minor veins on both surfaces, with conspicuous granular surfaces below.

Philodendron condorcanquense is similar to $P$. exile in having narrowly ovate blades, less than 2.2 times lonter than wide, however, $P$. condorcanquense has lower blade surfaces with distinctly raised minor veins (as opposed to minor veins scarcely discernable on the lower blade surface in $P$. exile), no laticifers (laticifers present, although not prominently visible in $P$. exile), and one inflorescence per axil ( 2 inflorescences per axil in $P$. exile).

Philodendron huashikatii Croat, sp. nov. Type: Perú. Amazonas: Río Cenepa, vic. Huampami, ca. $5 \mathrm{~km}$ E of Chávez Valdívia, ca. $4^{\circ} 30^{\prime} \mathrm{S}, 78^{\circ} 30^{\prime} \mathrm{W}, 200-250 \mathrm{~m}, 3 \mathrm{~km}$ above the mouth of the Huampami, 25 July 1978, E.
Ancuash 1130 (holotype, MO-2672320; isotypes, K, US, USM). Fig. 10a.

Planta hemiepiphytica; internodia 1-2 cm longa; cataphylla (6) 9-14 cm longa, 2-6 mm lata; petioli (11-15) 18-26 cm longi, 4-5 mm lati; lamina oblonga-oblanceolatae, 49 cm longae, $14.5 \mathrm{~cm}$ latae; nervis primariis lateralis 8-14 utroque; inflorescentia 1-4 per quoque axila; pedunculus 4.2-6.5 cm longus, $2.5 \mathrm{~mm}$ diam in sicco; spatha viridis, 6.3-8.3 cm longa.

Hemiepiphytic appressed climber; internodes $1-2 \mathrm{~cm}$ long, light tan-brown, semiglossy, with epidermis transversely fissured, peeling; roots few at each node, to less than $10 \mathrm{~cm}$ long, drying reddish brown, densely puberulent; drying 5-7 $\mathrm{mm}$ wide; cataphylls (6) $9-14 \mathrm{~cm} \times 3-6 \mathrm{~mm}$ at base to 2-4 mm wide near apex, drying medium brown to dark olive-green. Petioles subterete, with a dark purple ring at the apex, drying ribbed, (11-15) 18-26 cm × 4-5 mm; blades oblong-oblanceolate, $49 \times 14.5 \mathrm{~cm}$, drying dark grayish green to grayish brown, rarely tinged weakly with yellow above, yellowish green to grayish green below, gradually to abruptly long-acuminate at apex, cordulate, sometimes rounded-truncate at the base; sinus to $1.7 \mathrm{~cm}$ deep; midrib thickly convex and concolorous above, convex below, drying convex and concolorous above, bluntly acute and brownish below, darker than the surface; primary lateral veins $8-14$ per side, arising at $60-90^{\circ}$ angle, weakly arched to the margins, drying weakly raised and concolorous above, weakly raised with several weak ribs paler than surface below; minor veins moderately conspicuous, weakly raised and frequently minutely undulate on drying sometimes with weak cross-veins visible below. Inflorescence 1 to 4 per axil; peduncle $4.2-6.5 \mathrm{~cm}$ long (13$14 \mathrm{~cm}$ long in fruit), drying dark brown, 2.5 $\mathrm{mm}$ diam., matte; spathe green, $6.3-8.3 \mathrm{~cm}$ long, drying 7-1.7 cm diam., dark yellowish brown, matte; spadix drying reddish brown or cream-tan, 4-9 $\times 0.5-1 \mathrm{~cm}$ at midpoint, pistillate portion $4-5 \times 0.8-1.1 \mathrm{~cm}$, pistils 2 
$\times 2 \mathrm{~mm}$, sides ribbed, minutely granular; style $0.8-0.9 \mathrm{~mm}$ wide, quadrangular to subrounded, minutely granular on drying at high magnification; stigma funnel-shaped, $0.15 \mathrm{~mm}$ diam., raised above the style; ovary 4-locular; ovules 1 per locule; seeds narrowly fusiform, $1.4 \times 0.4 \mathrm{~mm}$, tapered weakly toward both ends, light brown.

Local Aguaruna names: 'chinchip daék' 'chinchip sugkip', 'chineschip daék' 'chu daék'.

Philodendron huashikatii is a member of section Calostigma, series Belocardium, and is currently known only from Amazonas Department in Peru at 180-400 $\mathrm{m}$ in Tropical wet forest (T-wf) and Premontane wet forest (P-wf) life zones.

A sterile specimen from San Martín (Croat 57989) is very similar in blade shape, size and coloration, but that collection lacks cross-veins and has minor veins alternating with resin canals.

Philodendron huashikatii is most similar to P. uleanum Engl., which has similar leaves and is in the same section and series, but $P$. uleanum has larger inflorescences to 15-22 cm long, peduncles 6-11 cm long, spathes 9-12.5 × 1.5-2.5 cm, and dries dark reddish brown.

This species is named for Victor Huashikat, an Aguaruna Indian plant collector who assisted Brent Berlin on his ethnobotanical research expeditions to the Alto Marañón river region in northern Perú.

Paratypes: AMAZONAS: Río Santiago, 2 $\mathrm{km}$ behind Caterpiza, $180 \mathrm{~m}$, Huashikat 858 (MO); 1018 (MO); 2-3 km behind Caterpiza, 200 m, 14 Jan. 1980, Tunqui 610 (MO); Condorcanqui, Río Cenepa, Huampami, $4^{\circ} 28^{\prime}$ 'S, 78 ${ }^{\circ} 10^{\prime} \mathrm{W}, 189-213 \mathrm{~m}, 22$ Aug. 1976, Boster 74 (MO); El Cenepa, Tutino, 4³3'05"S, 78¹2"54"W, 400 m, 20 July 1997, Vasquez et al. 24386 (MO).

Philodendron palaciosii Croat \& Grayum, sp. nov. Type: Ecuador. Napo: Tena Cantón, Est. Biol. Jatun Sacha, along S bank of Río Napo, $8 \mathrm{~km}$ E of Puerto Misahualii, $1^{\circ} 04$ 's,
77³6'W, 450 m, 1 Apr. 1992, T. B. Croat 73380 (holotype, MO-04756557; isotypes, AAU, B, CAS, F, K, MEXU, NY, QCNE, US). Fig. 10b, c, d.

Planta terestris vel hemiepiphytica; internodia 1-4(6) cm longa, 7-15 mm diam.; petioli $12-23 \mathrm{~cm}$ longi; laminae ovatae vel ovatae-ellipticae, $19.5-29 \mathrm{~cm}$ longae, (7.8) $10-13.7 \mathrm{~cm}$ latae; nervis primariis lateralibus 13-17 utroque; pedunculus 10$16 \mathrm{~cm}$ longus, 3-4 mm diam.; spatha 11.5-16 cm longa, 1.5-1.7 (3) cm lata, alba vel cremea vel primulina; spadice 6-15 cm longus; pars pistillata 2-3.3 cm longa, 7-9 mm diam.; pars staminata $5-5.5 \mathrm{~cm}$ longa.

Terrestrial or hemiepiphytic, $0.5-1 \mathrm{~m}$ tall or appressed climbing to $3 \mathrm{~m}$; stem sometimes decumbent or pendent, $1-1.2 \mathrm{~cm}$ diam., internodes 1-4 (6) × 7-15 cm diam., matte, gray-green to olive-green, drying ribbed, weakly striate. Petioles $12-23 \mathrm{~cm}$ long, dark green to yellowish brown, matte and finely costate, minutely granular on surface, sheathed to near the middle or up to $1 \mathrm{~cm}$ below blade attachment, sheath broadly winged, splayed widely at apex to $3.4 \mathrm{~cm}$ wide when flattened, rounded and weakly freeending at apex, the free portion of petiole sharply and deeply D-shaped, 2-3 mm diam.; blades subcoriaceous, ovate to ovate-elliptic, 19.5-29 × (7.8)10-13.7 cm, 1.6-2.3 times longer than wide, 1.2-1.6 times longer than petioles, gradually long-acuminate at apex, prominently decurrent at base, bicolorous, subvelvety matte, dark green (sometimes almost blackened) drying matte and gray above, paler, matte and yellow-green to graygreen below; midrib broadly convex and slightly paler to concolorous, finely costate above, broadly convex and paler, minutely granular below; primary lateral veins 1317 per side, mostly aggregated near the base, arising in a sweeping curve (especially those near the base) at an acute angle then spreading at $40-70^{\circ}$ angle, minutely undulate and scarcely more prominent than the minor veins on upper surface, weakly raised and paler than surface below, minor veins moderately 
obscure. Inflorescence 1 per axil, rarely 2 per axil (Croat et al. 87854); peduncle $10-16 \mathrm{~cm}$ $\times$ 3-4 mm, medium green with dark green striations, drying yellowish green, dark brown or pale yellow-brown; spathe $11.5-16 \times 1.5-$ 1.7 (3) $\mathrm{cm}$, white to creamy white, or greenish yellow, the spathe tube green, the lower $2 / 3$ of the entire inner surface greenish white, lined with intermittant red streaks, drying greenish yellow-brown, pale green within post anthesis with brown resin canals; spadix $6-$ $15 \mathrm{~cm}$ long, elongating in fruit with the staminate spadix protruding slightly beyond the end of the spathe, creamy white; pistillate portion $2-3.3 \mathrm{~cm} \times 7-9 \mathrm{~mm}$, pale green to pale yellow-green; staminate portion $5-5.5 \mathrm{~cm}$ long, the sterile staminate portion $1 \mathrm{~cm} \times 8$ mm diam.; pistils $1.8 \times 7-9 \mathrm{~mm}$, densely and minutely warty at apex; stigma $0.5-0.6 \mathrm{~mm}$ diam., drying dark brown, the style apron to $1 \mathrm{~mm}$ wide, pale brown. Infructescence orange.

Philodendron palaciosii ranges from Central Ecuador (Napo, Pastaza, Morona-Santiago) to Peru (Amazonas, San Martín) at 350 $1700 \mathrm{~m}$ elevation in Tropical moist forest (T$\mathrm{mf}$ ), Tropical wet forest (T-wf), Premontane moist forest (P-mf), and Premontane rain forest (P-rf) life zones.

The species is a member of subgenus Pteromischum and is characterized by mattedrying, pale yellow-green blades which are ovate and attenuated at the base.

The species is named in honor of Walter Palacios, Ecuadorian botanist, who is currently with the Jatun Sacha Foundation and was first to collect this species while working for the National Herbarium of Ecuador (QCNE).

Paratypes: ECUADOR. MORONA-SANTIAGO: Macas-Riobamba, Proaño-Par. Nac. Sangay, $28.6 \mathrm{~km} \mathrm{~W}$ of Proaño, $2^{\circ} 14^{\prime} 31$ "S, 78 $16^{\prime} 40^{\prime \prime W}, 1659$ m, 13 Aug. 2002, Croat et al. 86552 (MO); Patuca-Santiago along S edge of Cordillera del Cutució, entering from main Limón-Macas rd. at $44.6 \mathrm{~km} \mathrm{~N}$ of Limón, $3.9 \mathrm{~km}$ from Bella Union and jct. to Méndez,
$23.9 \mathrm{~km}$ from jct., $2^{\circ} 51^{\prime} 58^{\prime \prime} \mathrm{S}, 78^{\circ} 14^{\prime} 51^{\prime \prime} \mathrm{W}$, 250 m, 9 Sep. 2002, Croat 87337 (MO); Santiago-Río Morona and San José de Morona, 5 $\mathrm{km}$ E of Río Morona ferry crossing, $55.3 \mathrm{~km}$ E of Santiago, flood plain of Río Morona, 2॰53'30"S, 7742' 59"W, 300 m, 10 Sep. 2002, Croat 87441 (MO); W de la ciudad del Macas, $2^{\circ} 18^{\prime}$ 'S, $78^{\circ} 07^{\prime} \mathrm{W}, 1160 \mathrm{~m}, 24$ Feb. 1986, M. Baker 6611 (NY); $33.7 \mathrm{~km}$ E of Santiago, $523 \mathrm{~m}$, Croat et al. 90711 (MO, QAP); Morona, Macas-Puyo, $31 \mathrm{~km} \mathrm{~N}$ of Macas, $28.5 \mathrm{~km} \mathrm{~N}$ of bridge over Río Upano, $2^{\circ} 01^{\prime} \mathrm{S}$, 7756'W, 1125 m, 7 Mar. 1992, Croat 72796 (MO, QCNE). NAPO: Baeza-Lago Agrio, along rd. at $\mathrm{km} 154.5,0^{\circ} 22^{\prime} \mathrm{S}, 77^{\circ} 50^{\prime} \mathrm{W}, 1750$ m, 2 Oct. 1980, Croat 50286 (MO); 39 km $\mathrm{NE}$ of jct. of rd. to Tena, $19.7 \mathrm{~km} \mathrm{NE}$ of El Chaco, $141 \mathrm{~km} \mathrm{SW}$ of Lago Agrio, $1750 \mathrm{~m}$, 26 Apr. 1984, Croat 58537 (MO); creek 3.5 $\mathrm{km}$ NW of Borja, $0^{\circ} 24^{\prime} \mathrm{S}, 77^{\circ} 50^{\prime} \mathrm{W}, 1850 \mathrm{~m}$, 20 Sep. 1980, Holm-Nielsen et al. 26348 (AAU); Tena-Puyo, $5.5 \mathrm{~km} \mathrm{~S}$ of bridge over Río Napo, ca. $1^{\circ} 05^{`} \mathrm{~S}, 77^{\circ} 47^{\prime} \mathrm{W}, 510 \mathrm{~m}, 2$ May 1984, Croat 58920 (MO); $4.7 \mathrm{~km} \mathrm{~S}$ of Puerto Napo (bridge over Rio Napo), $1^{\circ} 10^{\prime}$ 'S, $77^{\circ} 50^{\prime} \mathrm{W}, 650 \mathrm{~m}, 6$ Apr. 1089, Thomas \& Rios 6664 (MO, NY); km 20, 430 m, 20 July 1982, Besse et al. 1672 (MO, SEL); rd. N from El Chaco, Quito-Lago Agrio Rd., $20 \mathrm{~km}$ E of Baeza, $0^{\circ} 15^{\prime} \mathrm{S}, 77^{\circ} 50^{\prime} \mathrm{W}, 1500 \mathrm{~m}$, 22 July 1986, Gentry \& Miller 55004 (MO); BaezaEl Chaco, vic. Río Sardinas Grande, along Río Quijos, $6 \mathrm{~km}$ NNE of San Francisco Borja, 0²2’32"S, 7749’01"W, 1767 m, 17 Apr. 2003, Croat et al. 87667 (MO); along rd. to Mushullacta, $1-5 \mathrm{~km}$ S of Main Narupa-Coca Rd., vic. Par. Nac. Napo-Galleras; 042'S, 77³6'W, 1500 m, 20 Apr. 2003, Croat et al. 87854 (AAU, B, BR, CAS, COL, CUVC, F, GB, GH, HUA, INB, K, M, MEXU, MO, NY, SEL, US); along rd. SE of Francisco de Orelleno (Coco) to El Auca $14.6 \mathrm{~km}$ past bridge over Río Napo, 0`37’S, 76²0’W, 450 m, 5 Oct. 1980, Croat 50378 (MO); Lago AgrioBaeza at ca. km 107, $1^{\circ} 05^{\prime} \mathrm{S}, 77^{\circ} 30^{\prime} \mathrm{W}, 1410$ m, 6 Oct. 1980, Croat 50485 (MO); Nor-Ori- 
ente, Nuevo Rocafuerte, colecciones al SurOeste de la población, 200-230 m, 2 Mar. 1981, Jaramillo \& Coello 4621 (QCA); Est. Biol. Jatun Sacha, 400 m, 3 Apr. 1998, M. Schwerdtfeger 98030402 (MO); 300 m, 10 Mar. 1995, Schwerdtfeger 031015 (MO); Río Napo, $8 \mathrm{~km}$ below Misahuallí, $1^{\circ} 04$ 'S, 77³6’W, 450 m, 17 Jan.-6 Feb 1987, Cerón 596 (QCNE); $8 \mathrm{~km}$ al E de Misahuallí, $1^{\circ} 04$ 'S, 77³6’W, 450 m, 19-28 Mar 1987, Cerón 971 (MO, QCNE); parcela permanente $3,1^{\circ} 04$ 'S, 77³6’W, 19-23 Mar. 1989, Cerón 6367 (MO, QCNE); 8 km de Puerto Misahuallí, margen derecha del Río Napo, $1^{\circ} 04^{\prime}$ 'S, $77^{\circ} 36^{\prime} \mathrm{W}, 8$ Nov. 1987, Cerón 2577 (MO, QCNE); along $\mathrm{S}$ bank of Río Napo, $8 \mathrm{~km}$ E of Puerto Misahualii, $1^{\circ} 04^{\prime}$ 'S, $77^{\circ} 36^{\prime} \mathrm{W}, 1$ Apr. 1992, Croat 73380 (AAU, B, CAS, F, K, MEXU, NY, QCNE, US); Sumaco, Cantón Archidona, Carretera Hollín-Loreto, km 25, Centro Challuayacu, $0^{\circ} 43^{\prime} \mathrm{S}, 77^{\circ} 40^{\prime} \mathrm{W}, 1230 \mathrm{~m}, 10$ 19 Nov. 1988, Hurtado \& Alvarado 1075 (MO); entre el Río Pucuno y el Cacerío de Guamaní, 046'S, 77²6'W, 1200 m, 12 Dec. 1987, Cerón 2967 (MO, QCNE); km 25, Sector Challua Yacu, Faldas al sur del Volcán Sumaco, $0^{\circ} 45^{\prime} \mathrm{S}, 7^{\circ} 38^{\prime} \mathrm{W}, 1200 \mathrm{~m}, 21-27$ Apr. 1989, Cerón \& Hurtado 6506 (MO); km 50, Guagua Sumaco, Faldas al sur del Volcán Sumaco, Informante: Pedro Avilés, $0^{\circ} 38^{\prime} \mathrm{S}$, 77²7'W, 1000 m, 29 Apr.-2 May 1989, Cerón \& Hurtado 6687 (MO); km 31, Comuna Challua Yacu, Suelos volcánicos,

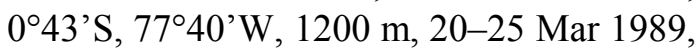
Palacios 4047 (MO, QCNE, QAP). PASTAZA: vic. of Shell, along Río Pindo, ca. $1.5 \mathrm{~km} \mathrm{~N}$ of Shell, $0^{\circ} 29^{\prime} 39^{\prime \prime} \mathrm{S}$, 78 03'52"W, 1085 m, 5 May 2003, Croat et al. 88574 (MO); Mera-Río Anzu, $8.3 \mathrm{~km} \mathrm{~N}$ of Mera, $1^{\circ} 25^{\prime} 56^{\prime} \mathrm{S}, 78^{\circ} 04^{\prime} 54^{\prime \prime} \mathrm{W}, 1300 \mathrm{~m}, 6$ May 2003, Croat et al. 88659 (MO); $7.7 \mathrm{~km}$ $\mathrm{N}$ of Río Alpayacu, $1^{\circ} 25^{\prime} 51^{\prime \prime} \mathrm{S}, 7^{\circ} 04^{\prime} 34^{\prime \prime} \mathrm{W}$, 1267 m, 8 May 2003, Croat et al. 88862 (MO); Río Villano, $1^{\circ} 24^{\prime} \mathrm{S}, 77^{\circ} 02^{\prime} \mathrm{W}, 260 \mathrm{~m}$, 24 Mar. 1980, Holm-Nielsen et al. 22658 (AAU); $1^{\circ} 25^{\prime} \mathrm{S} 77^{\circ} 02^{\prime} \mathrm{W}, 260 \mathrm{~m}, 24 \mathrm{Mar}$. 1980, Holm-Nielsen 22714 (AAU); Curaray, ridge NE of Destacamanto, $1^{\circ} 21^{\prime} \mathrm{S}, 76^{\circ} 56^{\prime} \mathrm{W}$, 250 m, 19 Mar. 1980, Holm-Nielsen et al. 22080 (AAU); 21990 (AAU); N bank $2 \mathrm{~km}$ $\mathrm{W}$ of the school, $1^{\circ} 22^{\prime} \mathrm{S}, 76^{\circ} 58^{\prime} \mathrm{W}, 250 \mathrm{~m}, 18$ Mar. 1980, Holm-Nielsen et al. 21844 (AAU); 200 m, 20 Mar. 1980, Harling \& Andersson 17559 (GB); Valle de la Muerte, $1^{\circ} 25^{\prime} \mathrm{S}$ 7652'03"W, 240 m, 22 Mar. 1980, HolmNielsen et al. 22466 (AAU); Toñampari, poblacion Waorani (Aucas), Centro Oriente, sector izquierdo en la cuenca del Rio Curaray, $1^{\circ} 12^{\prime} \mathrm{S}, 77^{\circ} 20^{\prime} \mathrm{W}, 400-500 \mathrm{~m}, 14$ Aug. 1980, Jaramillo \& Coello 3508 (QCA); Río Tinguiza, in the vic. of Canelos, 15 Mar. 1971, Lugo 1687 (MO); Villano, Cantón Puyo, Comunidad Santa Cecilia, Suelo con capa mate-ria orgánica de hasta $40 \mathrm{~cm}$ de profundidad, bien drenado, $1^{\circ} 30^{\prime} \mathrm{S}, 77^{\circ} 27^{\prime} \mathrm{W}$, 380 m, 1 May 1992, Palacios 10073 (MO, QCNE); 10087 (MO, QCNE); Pozo petrolero "Ramirez", $20 \mathrm{~km}$ al sur de la población de Curaray, $1^{\circ} 32^{\prime}$ 'S, $76^{\circ} 51^{\prime} \mathrm{W}, 300 \mathrm{~m}, 21-28 \mathrm{Feb}$. 1990, Zak \& Espinoza 4831 (MO, QCNE); 5265 (MO); 5266 (QCNE); 5279 (MO, QCNE); Shell-Mera, $5.3 \mathrm{~km} \mathrm{NW}$ of center of Shell, along gravel $\mathrm{rd}, 1.1 \mathrm{~km} \mathrm{~N}$ of hwy, E end of rd., $1^{\circ} 27^{\prime} \mathrm{S}, 78^{\circ} 04^{\prime} \mathrm{W}, 1180 \mathrm{~m}, 3$ Apr. 1992, Croat 73460 (MO, QCNE); Mera-Río Anzu, $11.7 \mathrm{~km} \mathrm{~N}$ of main plaza in Mera (located on Puyo-Baños Rd), $1^{\circ} 20^{\prime} \mathrm{S}$, 7806'W, 1350-1380 m, 5 Apr. 1992, Croat 73583 (MO, QCNE). ORELLANA: Tiputini Biodiv. St., 0`38'S, 7609'W, 200 m, 21 Feb. 2002, Koster et al. 1008 (MO). SUCUMBIOS: Lago Agrio, Lago AgrioCoca, $26 \mathrm{~km} \mathrm{~S}$ of Lago Agrio, $4.6 \mathrm{~km} \mathrm{~S}$ of El Emo, then $2.8 \mathrm{~km} \mathrm{~W}$ of main Lago AgrioCoca Rd, $0^{\circ} 05^{\prime}$ 'S, 76 $54^{\prime} \mathrm{W}, 355$ m, 29 Feb. 1992, Croat 72501 (MO, QCNE). ZAMORACHINCHIPE: Los Encuentros-El Sarsa, Cordillera del Cóndor, $14.4 \mathrm{~km}$ SE of Los Encuentros, $3^{\circ} 47^{\prime} 44^{\prime \prime} \mathrm{S}, 7^{\circ} 37^{\prime} 01^{\prime \prime} \mathrm{W}, 1188 \mathrm{~m}$, 26 May 2003, Croat \& Menke 89487 (MO). PERU. AMAZONAS: Ba-gua, Imaza, Yamayakat, $5^{\circ} 03^{\prime} 24^{\prime \prime} \mathrm{S}, 78^{\circ} 20^{\prime} 17^{\prime \prime} \mathrm{W}, 350 \mathrm{~m}$, 25 Mar. 2000, Vásquez 26509 (MO); Shimutáz, Imaza, Margen derecha quebrada, 
Shimutáz, 2 hrs. de surcada desde la boca (con-fluencia con el Marañon), 400-550 m, 21 Oct. 1995, Díaz et al. 7683 (MO); KusuChapi, Región del Marañon, Area permanente 500 x $500 \mathrm{~m}$, parcela “ $E$ ", $4^{\circ} 55^{\prime} \mathrm{S}, 78^{\circ} 19^{\prime} \mathrm{W}$, 350 m, Feb. 1995, Vasquez et al. 20041 (MO); Condorcanqui, Valle del Rio Santiago, Caterpiza, 2-3 km atrás de la comunidad de Caterpiza, $3^{\circ} 50^{\prime} \mathrm{S}, 77^{\circ} 40^{\prime} \mathrm{W}, 180 \mathrm{~m}, 20 \mathrm{Feb}$. 1980, Tunqui 927 (MO). SAN MARTÍN: Mariscal Caceres, Tocache Nuevo, Al E de Tocache, cerca a la Chacra del Sr. Estaban Arévalo, 500-700 m, 14 Oct. 1980, SchunkeVigo 12365 (MO).

Cultivated Plants: Cultivated at Waimea Arboretum and Botanical Garden, originally vouchered by Lyon 82-1465, Waimea 83-919, vouchered on 29 Apr. 1994 as Croat 76162 (MO).
Philodendron reticulatum Grayum, sp. nov. Type: Perú. Amazonas: Río Cenepa, vic. of Huampami, ca. $5 \mathrm{~km}$ E of Chávez Valdivia, along Chigkan Entsa, Aintami, ca. 4³0'S, 78³0'W, 200-250 m, 17 Aug. 1978, A. Kujikat 449 (holotype, MO-2674229). Fig. 11a.

Planta hemiepiphytica; internodia 1-2.5 $\mathrm{cm}$ longa; petioli $14.5 \mathrm{~cm}$ longi; laminae anguste ellipticae, 25.6-29.5 cm longae, 9.5$10.1 \mathrm{~cm}$ latae; nervis primariis lateralibus 8 9 utroque; pedunculus $3 \mathrm{~cm}$ longus; spatha $6.5 \mathrm{~cm}$ longa, $11 \mathrm{~mm}$ diam.; spadice $4.4 \mathrm{~cm}$ longus; parte pistillata 1.9-2.2 cm longa, 9 mm diam.

Hemiepiphytic climber; internodes 1-2.5 $\mathrm{cm}$ long, drying matte, medium to dark yellowbrown, closely folded-ridged. Petioles $14.5 \mathrm{~cm}$ long, sheathed to the base of blade or to within $6 \mathrm{~mm}$ of the base; sheath erect, drying yellowgreen, many ribbed, matte; free portion of petiole sharply sulcate; blades narrowly elliptic, 25.6$29.5 \times 9.5-10.1 \mathrm{~cm}, 2.6-2.9$ times longer than wide, 2-3.1 times longer than petioles, gradually long-acuminate at apex, narrowly rounded at base, markedly inequilateral, one side 2.1-2.2 $\mathrm{cm}$ wider, dark green and semiglossy above, paler and semiglossy below, drying gray above, yellow-green below; midrib weakly sunken and paler, dark-speckled above, narrowly roundraised, yellow-brown and finely striate below; primary lateral veins $8-9$ per side, arising at a steep angle then spreading at $60-70^{\circ}$ angle, drying weakly raised and scarcely more apparent than the interprimary veins above, convex to narrowly rounded and moderately paler below with whitish stitching along margins; cross-veins moderately conspicuous below, less so on upper surface; the surface weakly pale punctate-lineate above, more conspicuously below. Inflorescence solitary; peduncle $3 \mathrm{~cm} \times 2-3 \mathrm{~mm}$, drying yellowbrown, drying dark short-lineate near apex; spathe $6.5 \mathrm{~cm} \times 11 \mathrm{~mm}$, drying dark yellowbrown, matte; spadix $4.4 \mathrm{~cm}$ long; pistillate portion 1.9-2.2 cm $\times 9 \mathrm{~mm}$; style $0.8-1.2 \mathrm{~mm}$ diam., with a broad, thin apron; stigma 0.6$0.7 \mathrm{~mm}$ diam., donut-shaped; staminate portion $1.4 \mathrm{~cm}$ long, narrowly tapered $2 \mathrm{~mm}$ 


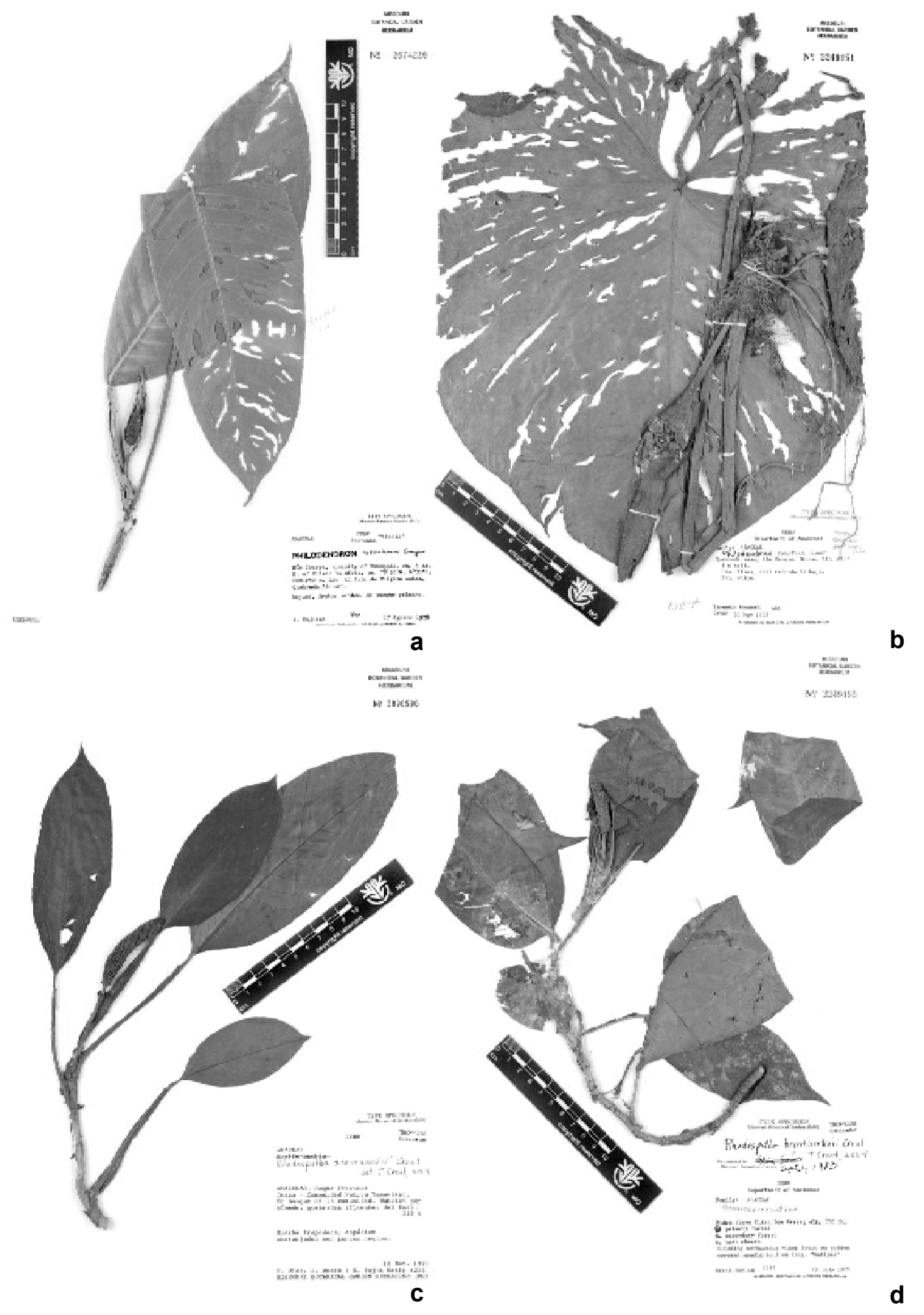

Figure 11 - a. Philodendron reticulatum Grayum. Type specimen. (Kujikat 449); b. Philodendron swartiae Croat. Type specimen. (Ancuash 486); c. Rhodospatha acosta-solisii Croat. Type specimen. (Díaz et al. 4232); d. Rhodospatha brent-berlinii Croat. Type specimen. (Berlin 1613) 
diam.

Local Aguaruna name: timtik.

Philodendron reticulatum is known only from the type specimen in Amazonas Department in Peru at 200-250 m elevation in Tropical wet forest (T-wf) and Premontane wet forest (P-wf) life zones.

The species is a member of subgenus Pteromischum and is characterized by closely folded yellow-brown drying stems, nearly fully sheathed narrow petioles, narrowly elliptic blades which dry yellow-green below with prominent cross-veins giving the surface a prominent reticulate venation (hence the specific epithet "reticulatum").

Philodendron swartiae Croat, sp. nov. Type: Perú. Amazonas: Río Cenepa, Quebrada Sasa, 910 m, 2 June 1973, E. Ancuash 486 (holotype, MO-2249161; istotype USM). Fig. $11 \mathrm{~b}$.

Planta terrestris, ad $90 \mathrm{~cm}$; internodia brevia, 1.5-2 cm diam.; cataphylla ad. $10 \mathrm{~cm}$ longa; petioli 62-63 cm longi, 4-7 mm diam. in sicco; laminae late ovato-cordatae, 36-40 cm longae, 32-33 cm latae, profunde cordatae ad basim; lobulae posticus 14-16 cm longus, 12-15 cm latus; nervis primaribus lateralibus 3 utroque; pedunculus 7.5-12 cm longus, 4$5 \mathrm{~mm}$ lata; spatha alba, $14.5 \mathrm{~cm}$ longa; tubo $7 \mathrm{~cm}$ longo, $3 \mathrm{~cm}$ lato; ovarium 5-locularibus; ca. 20 ovula per loculum.

Terrestrial, to $90 \mathrm{~cm}$ tall; internodes short, 1.5-2 cm diam.; cataphylls ca. $10 \mathrm{~cm}$ long, unribbed, drying thin, reddish brown, soon weathering to pale fibers. Petioles 62$63 \mathrm{~cm}$ long, drying 4-7 cm wide, light reddish brown, matte, densely and conspicuously warty-verrucose-scaly throughout, especially near the apex, the scales stalked, especially toward apex, blunt and knob-like at apex, sometimes with as many as 3 knobby excressences per stalk, the glands becoming sparce toward the base and shorter, merely warty, non-stalked excrescences; geniculum ca. $2 \mathrm{~cm}$ long, not conspicuously different that the petiole on dried material; blade broadly ovate-cordate, $36-40 \times 32-33 \mathrm{~cm}, 1.5-1.7 \mathrm{ti}-$ mes longer than wide, more or less rounded and weakly acuminate at apex, deeply cordate at base, drying weakly glossy, gray-green above, grayish yellow-brown and weakly glossy below; anterior lobe 24-28 cm long, broadest about $6 \mathrm{~cm}$ above petiole attachment; sinus spathulate (closed or nearly so), 11.5$13 \mathrm{~cm}$ deep, $2.6-2.8 \mathrm{~cm}$ wide when flattened; posterior lobes $14-16 \times 12-15 \mathrm{~cm}$; basal veins 5-6 pairs, the first $1^{\text {st }}$ and $2^{\text {nd }}$ free to the base, the $1^{\text {st }}$ pair turned down prominently along sharply along the midrib, the $3^{\text {rd }}$ and higher order veins closely contiguous and almost fused for $1-1.5 \mathrm{~cm}$, some of the basal veins branched about midway; midrib drying broadly convex, finely ribbed above, bluntly acute, finely ribbed below; primary lateral veins 3 per side, arising at an acute angle then spreading at $55-60^{\circ}$ angle, flat and concolorous above, narrowly raised and reddish brown, darker than surface below; minor veins drying prominently undulate on both surfaces. Inflorescence with peduncle 7.5-12 cm long, drying 4-5 mm wide, medium reddish brown, bluntly striate; spathe white, drying reddish brown, $14.5 \mathrm{~cm}$ long, prominently constricted above the tube; tube $7 \times 3 \mathrm{~cm}$; pistils $2.5 \times 1 \mathrm{~mm}$; ovary 5 -locular, the side densely purplish short-lineatepunctate; locules with ca. 20 ovules, with axile placentation; seeds 7-9 × 3-4 mm, coarsely longitudinally 8-12 ribbed around the sides.

Philodendron swartiae is known only from the type specimen along the Río Cenepa at $304 \mathrm{~m}$ in the Tropical wet forest (T-wf) life zone.

The species is recognized by terrestrial habit, creeping stems, persistent cataphyll fibers, densely warty-verrucose-scaly petioles, and ovate-cordate blades. Philodendron swartiae is related to other members in an unnamed section and species in the group include $P$. pastazanum K. Krause and P. gloriosum André. Philodendron pastazanum differs in having a peltate blade. Philodendron gloriosum, a species endemic 
to Colombia, differs in having the major veins prominently paler than the surface.

The species is named for Anne Swart, former research intern for the senior author through Washington University in St. Louis, where she was a student. During her research at the Missouri Botanical Garden she helped to sort and identify numerous specimens from the Río Cenepa region of Perú.

Rhodospatha acosta-solisii Croat, sp. nov. Type: Perú. Amazonas: Bagua, Imaza, Yamayakat, along creeks flowing into Río Kusú, 310 m, 18 Nov. 1990, C. Diaz, J. Amaro \& S. Yujna Katip 4232 (holotype, MO3896596; isotype USM). Fig. 11c.

Planta terrestris vel hemiepiphytica; internodia 1.5-4 cm longa, 5-6 $\mathrm{mm}$ diam.; petioli $6.5-22 \mathrm{~cm}$ longi; laminae oblongolanceolatae vel oblongo-ellipticae, 12-18(27) cm longae, 2-8(9.2) cm latae; nervis primariis lateralibus (8)12-15(17) utroque; inflorescentia brevi-pedunculata; spadice stipitatus 10-12 mm, 6-8.5 cm longus, 2-5 $\mathrm{mm}$ diam. in sicco, viridis vel pallide aurantiacus; pistilla 1.2-1.5 mm diam.

Terrestrial or hemiepiphytic vine; internodes $1.5-4 \mathrm{~cm} \times 5-6 \mathrm{~mm}$, dark green to olive-green, semiglossy, becoming light brown to tan. Petioles sulcate to the base of the geniculum, $6.5-22 \mathrm{~cm}$ long, usually shorter than blade, $0.5-0.8$ times as long as blade, rarely about as long as blade, sulcate above sheath, sheath erect, margins thin and scarious, sometimes weakly free-ending at apex, in part deciduous; geniculum narrowly and sharply sulcate; blades oblong-lanceolate to oblong-elliptic, $12-18(27) \times 2-8(9.2) \mathrm{cm}$ wide, 2.7-6.8 times longer than wide, slightly inequilateral, one side $4-9 \mathrm{~mm}$ wider (the narrower side $0.72-0.84$ as wide as the wider side), sometimes weakly falcate, matte to weakly glossy, drying dark brown above, moderately paler and semiglossy, drying medium yellow-brown below, acuminate to gradually acuminate at apex, somewhat inequilateral and rounded to obtuse and sometimes briefly decurrent at base; midrib narrowly sunken and slightly paler above, round-raised and slightly paler below; primary lateral veins $(8) 12-15$ (17) per side, quilted-sunken above, pleated-raised below, mostly drying darker than surface; interprimary veins few, when present 1 per pair of primary veins, these usually interspersed with a pair of minor veins, clearly visible; minor veins distinct or obscure below. Inflorescence short-pedunculate, dark brown; spathe missing, leaving a prominent ring-like scar; spadix stipitate $10-12 \mathrm{~mm}, 6-8.5 \mathrm{~cm}$ long, drying $2-5 \mathrm{~mm}$ diam., green to pale orange; pistils $1.2-1.5 \mathrm{~mm}$ diam, irregularly hexagonal, drying dark brown; stigma $0.8 \mathrm{~mm}$ long, drying black, surrounded by a pale peripheral ridge. Infructescence becoming red in early fruit to $13 \mathrm{~cm}$ long, $2.2 \mathrm{~cm}$ diam.

Rhodospatha acosta-solisii ranges from southern Ecuador (Zamora-Chinchipe) to northern Perú (Amazonas) in Tropical wet forest (T-wf), Premontane rain forest (P-rf), and Premontane wet forest (P-wf) life zones. It is recognized by its small dark-brown drying blades, and fully sheathed petioles with a deciduous sheath. The species is similar to $R$. latifolia in having brown drying blades and fully sheathed petioles, but differs in having a deciduous sheath. Croat 50760 from the Río Zamora in Loja Province has narrower and smaller blades than the other collections and is densely red-spotted on the lower surface when dry.

This species is named in honor of $\mathrm{M}$. Acosta-Solis, reknown Ecuadorian botanist who first collected the species on February 15, 1944 at Huamboya, which at the time was in Santiago-Zamora Province.

Paratypes: ECUADOR. ZAMORACHINCHIPE: Loja-Zamora, along Río Zamora near bridge that crosses Río Zamora, $39 \mathrm{~km}$ E of Loja, $4^{\circ} 05^{\prime} \mathrm{S}, 7^{\circ} 0^{\prime} \mathrm{W}, 1610 \mathrm{~m}$, 18 Oct. 1980, Croat 50760 (MO); entre La Esperanza y Santa Ana, Huamboya, Cordillera Oriental, 1500-2000 m, 15 Feb. 1944, M. Acosta-Solis 7413 (F); Loja-Zamora $13 \mathrm{~km} \mathrm{E}$ of Loja, 4ㄷ' $\mathrm{S}, 79^{\circ} 6^{\prime} \mathrm{W}, 2220 \mathrm{~m}, 18$ Oct. 
1980, Croat 50752 (MO); at Río Xamora, along steep slopes above bridge, $4^{\circ} 5^{\prime} \mathrm{S}, 79^{\circ}$ 00'W, 1610 m, 4 Mar. 1992, Croat 72691 (MO).
Rhodospatha brent-berlinii Croat, sp. nov. Type: Perú. Amazonas: Condorcanqui, ridge above Cikan Ece Creek, 228 m, 16 July 1974, B. Berlin 1613 (holotype, MO-2249195; isotype, USM). Fig. 11d.

Planta hemiepiphytica, scandens; internodia brevia, 7-10 cm longa, 4-5 $\mathrm{mm}$ diam.; petioli $4-4.5 \mathrm{~cm}$ longi, vaginatia ad geniculo; laminae anguste ovato-ellipticae, 14-18 cm longae, 6-7.5 cm latae; nervis primariis lateralibus 7-8 utroque; pedunculus $2.2 \mathrm{~cm}$ longus, $2.3 \mathrm{~cm}$ diam.; spadice 3.4-5 cm longus, $7 \mathrm{~mm}$ diam.; pistilla $1.4-1.6 \mathrm{~mm}$ diam.

Scandent hemiepiphytic; internodes slender, 7-10 cm $\times 4-5 \mathrm{~mm}$, drying yellowish brown, semiglossy, closely fissured-ridged with acute, irregular ridges, sometimes smooth. Petioles $4-4.5 \mathrm{~cm}$ long, fully sheathed to the geniculum, the margin thin, dark brown, ca. $2 \mathrm{~mm}$ high, soon breaking up, then deciduous; geniculum sharply sulcate, scarcely indistinguishable from the rest of the petioles; blades small, narrowly ovateelliptic, $14-18 \times 6.0-7.5 \mathrm{~cm}$, slightly inequilateral, one side ca. $6 \mathrm{~mm}$ wider than the other side, drying dark gray-green above, slightly paler and gray-green below, gradually acuminate at apex, slightly inequilatateral and mostly acute at base, sometimes with one side acute the other subrounded at base, but always weakly decurrent onto petiole; midrib drying $+/$ - flattened to weakly sunken, concolorous above, convex and $+/$ - concolorous below; primary lateral veins $7-8$ per side, arising at $50^{\circ}-60^{\circ}$, not very visible above, weakly raised and somewhat undulate below, not markedly more prominent than the interprimary veins, the latter also weakly undulate. Inflorescence small; peduncle short, $2.2 \mathrm{~cm} \times 2.3 \mathrm{~mm}$, drying yellowish brown, finely ridged; spadix $3.4-5 \mathrm{~cm} \times 7 \mathrm{~mm}$, golden-yellow, drying orange-brown, matte; pistils irregularly 5-6-sided, $1.4-1.6 \mathrm{~mm}$ wide; stigma round to broadly elliptic, drying blackened with a pale rim, $6-8 \mathrm{~mm}$ wide.

Rhodospatha brent-berlinii is endemic 


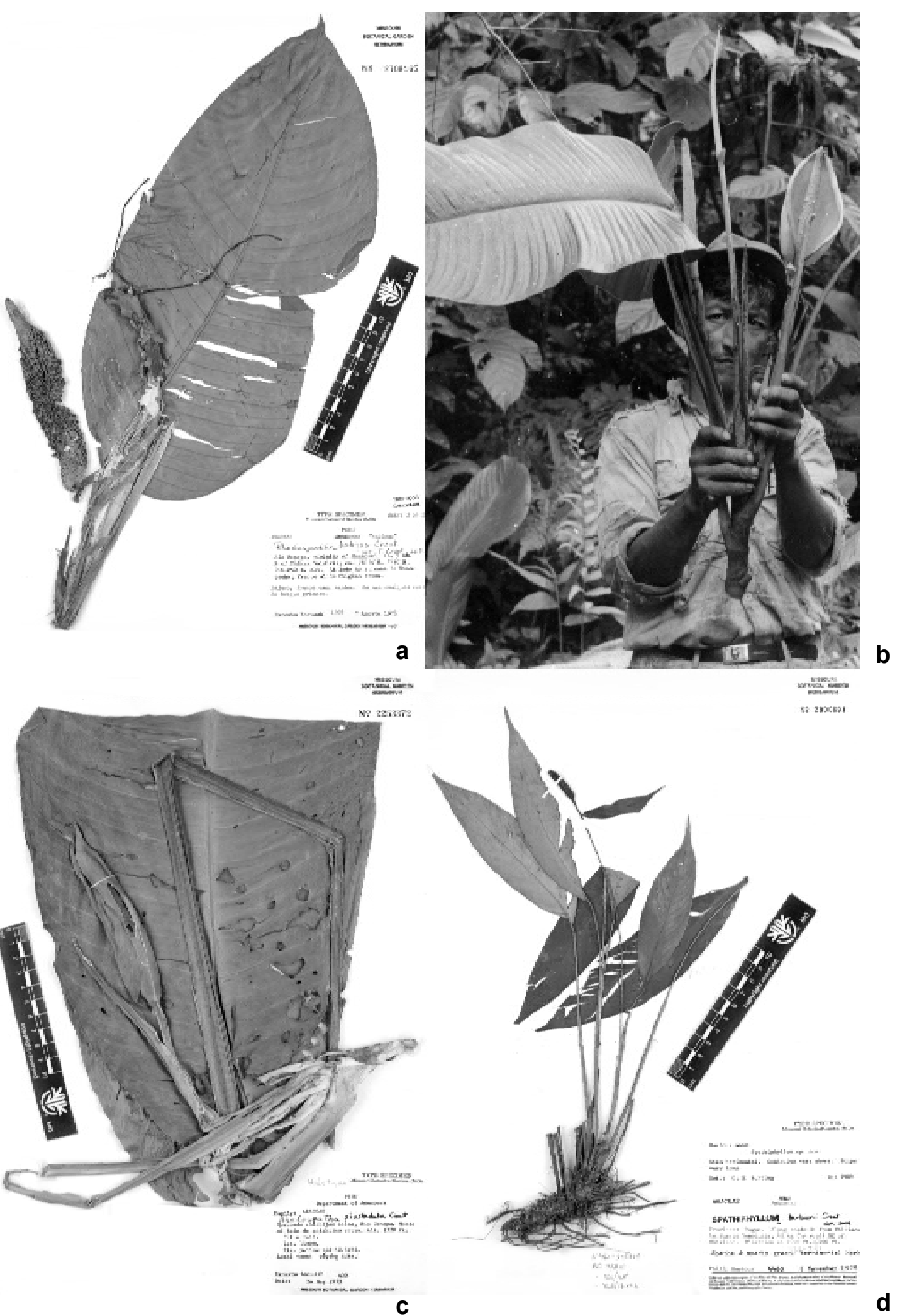

Figure 12 - a, b. Rhodospatha katipas Croat. a. type specimen. (Ancuash 1308); b. live plant showing leaf blade and inflorescence (Plowman 2057); c. Rhodospatha piushaduka Croat. Type specimen. (Ancuash 430); d. Spathiphyllum barbourii Croat. Type specimen. (Barbour 4460) 
to the type locality at $228 \mathrm{~m}$ in Tropical wet forest (T-wf) life zone. The species is characterized by its small size, short petiolate, narrowly ovate-elliptic leaves, and shortpedunculate, stubby golden-yellow spadix.

The species is closest to R. acosta-solisii Croat, which differs in having petioles less than $5 \mathrm{~cm}$ long, blades drying dark brown above and medium yellow-brown below, and the peduncle about 5 times longer than the stipe. Rhodospatha brent-berlinii has petioles $6.5-22 \mathrm{~cm}$ long, blades drying gray-green, and peduncles much shorter than the stipe.

This species is named in honor of Dr. Brent Berlin, anthropologist from the University of California, Berkely who made the first collection during linguistic studies among the native Aguaruna Indian populations of the Río Cenepa region.

Rhodospatha katipas Croat, sp. nov. Type: Perú. Amazonas: Río Cenepa, vic. of Huampami, ca. $5 \mathrm{~km}$ E of Chávez Valdívia, ca. $4^{\circ} 30^{\prime} \mathrm{S}, 78^{\circ} 30^{\prime} \mathrm{W}, 200-250 \mathrm{~m}, 7$ Aug. 1978, E. Ancuash 1308 (holotype, MO2708165; isotypes K, US, USM). Fig. 12a, b.

Planta hemiepiphytica; internodia 1-3 cm longa, 1-2 cm diam.; petioli 22-56 cm longi, vaginatuis ad geniculo; laminae anguste ovatae vel ellipticae, $26-65 \mathrm{~cm}$ longae $16.5-34 \mathrm{~cm}$ latae; nervis primariis lateralibus 22-44 utroque; pedunculus 6.5$24 \mathrm{~cm}$ longus; spadice 11-21.2 cm longus, 10 $15 \mathrm{~mm}$ diam.; pistilla 1.4-2 $\mathrm{mm}$ diam.

Appressed-climbing hemiepiphytic, to 2-4 m; internodes $1-3 \times 1-2 \mathrm{~cm}$, drying yellow-brown, smooth to longitudinally folded, sometimes transversely fissured, those in the upper part of the stem hidden by overlapping leaf bases; cataphylls deciduous or more commonly persisting as a network of fibers and patches of epidermis. Petioles 22$56 \mathrm{~cm}$ long (averaging $38 \mathrm{~cm}$ long), drying greenish brown, matte, mostly smooth, sometimes weakly folded, but never prominently ridged, sheathed to the geniculum (rarely ending 2-2.5 $\mathrm{cm}$ below the geniculum as in Kayap 1359), geniculum bluntly sulcate,
$2.5-3.5 \mathrm{~cm}$ long; blades narrowly ovate to elliptic, 26-65 × 16.5-34 cm, broadest at middle or slightly below the middle (averaging $35 \times 19 \mathrm{~cm}$ ) 1.5-2.8 times longer than wide, averaging 1.3-1.7 times longer than wide, 0.89-1.9 times longer than petioles, inequilateral, one side 1-2.6 times wider than the other, mostly rounded and abruptly acuminate sometimes acute and acuminate at apex, moderately inequilateral at base, one or both sides often weakly subcordate, one side often merely rounded, drying greenish brown to grayish brown above, gray-brown to reddish brown below; midrib deeply sunken above, thicker than broad, sparsely granular and with pale raphide cells below; primary lateral veins $22-40$ per side, $4-22 \mathrm{~mm}$ apart, mostly to $1 \mathrm{~cm}$ or more, closest near the base (to 4-5 $\mathrm{mm}$ apart), frequently arising at an acute angle then spreading at $66^{\circ}-90^{\circ}$ angle, straight to weakly curved to the margin, usually smooth, sometimes granular, sometimes pale with dark short lines in Peruvian populations; interprimary veins 1 , usually much smaller than the primary veins, along with the minor veins sometimes drying undulate; minor veins $2-4$ alternating between the primary and interprimary veins, sometimes sparsely granular; crossveins mostly oblique and obsure, mostly near the outer margins, sometimes throughout the surface; surface densely reddish granularpunctate; Inflorescence erect; peduncle 6.5$24 \mathrm{~cm}$ long, (averaging $14.5 \mathrm{~cm}$ long), 0.61.7 times longer than the spadix (averaging about as long as the spadix), spadix 11-21.2 $\mathrm{cm}$ long (averaging $15 \mathrm{~cm}$ long), $10-15 \mathrm{~mm}$ diam., to $20 \mathrm{~cm}$ in early fruit, broadest at about the middle, tapered somewhat to the base, substantially tapered to the apex, narrowly rounded at apex; pistils sometimes regularly 4-sided, sometimes irregularly 5-6 sided, 1.4$2 \mathrm{~mm}$ diam., the sides mostly straight, frequently convex, sometimes concave, the surface usually with a finely granular waxy layer, sometimes with fine pale globules of wax or the wax irregularly furrowed, usually faintly purplish brown, sometimes brown; 
stigmas mostly oblong-elliptic, black \& glossy, $0.6-0.8 \times 0.3-0.5 \mathrm{~mm}$, sunken medially; stamens included, anthers $1 \mathrm{~mm}$ long, $0.5 \mathrm{~mm}$ diam. Infructescence to $3 \mathrm{~cm}$ diam., pale red; seeds brown, subdiscoid, 1$1.2 \times 0.4-0.5 \mathrm{~mm}$, slightly broader in one dimension with a prominent notch on one end, with a sharp granular ridge around the outer margins.

Rhodospatha katipas ranges from southern Colombia (Putumayo \& Caquetá) to northern Perú (Amazonas) at $250-1000 \mathrm{~m}$ in Tropical moist forest (T-mf) and Premontane wet forest (P-wf) life zones. The species is characterized by appressed-climbing habit, moderately elongate internodes, petioles with deciduous and fibrous sheaths, the bluntly sulcate geniculum, more or less elliptic, slightly inequilateral blades with the blade rounded to weakly cordate, the midrib drying granular and with pale raphide cells visible on magnification, and moderately inconspicuous cross veins that are oblique and positioned relatively near the margins.

Rhodospatha katipas is most easily confused with $R$. mukuntachia Croat from Peru, Ecuador and Bolivia. That species differs in being terrestrial with short internodes hidden by the overlapping leaf bases, petiole sheaths not extending to the geniculum, the sharply sulcate geniculum, and blades with prominent cross veins extending throughout the surface of the leaves. In addition, the lower midrib of $R$. mukuntachia is densely and softly crustiose-puberulent on drying, rather than sparsely granular, as in $R$. katipas.

The species was first collected by Erik Asplund in November, 1939. However, since another species has already been named for both the first collector and the collector of the type, this epithet is based on the common local name for the species "katipas".

Paratypes: COLOMBIA. Caqueta, $10 \mathrm{~km} \mathrm{SW}$ of San José del Frague, SW of Florencia, 320 340 m, 10 Jan. 1974, Davidse et al. 5704 (COL, MO). PUTUMAYO: Mocoa, Schultes \& Cabrera 19045 (US); Villa Garzon, Río
Gineo, $8 \mathrm{~km}$ W of Villa Garzon, $<300 \mathrm{~m}, 22$ Nov. 1968, Plowman 2057 (F, GH). ECUADOR. NAPO: Río Cuyabeno, Pureto Bolivar, Siona, Jaramillo \& Criollo 2854 (MO); Tena, Asplund 8897 (MO); Res. Floristica "El Chuncho", Payamino, Est. INIAP-Napo, $0^{\circ} 30^{\prime} \mathrm{S}, 77^{\circ} 01 \mathrm{~W}, 250 \mathrm{~m}$, Cerón 2407; Río Aguarico, confluence of Río Pavayacu, Bravo \& Gomez 236. MORONASANTIAGO: Pumpuentza, WNW of village, $250 \mathrm{~m}$, Brandbyge \& Asanza 32333 (AAU); Pumpuentza, SSW of village, Brandbyge \& Asanza 32431 (AAU); Taisha, $77^{\circ} 30^{\prime} \mathrm{W}$, $2^{\circ} 23$ 'S, 450 m, 15 June 1980, Brandbyge \& Asanza 31879 (AAU, MO); Gualaquiza, Misión Bomboiza Salesiana, 700-800 m, Sparre 19139 (S). ZAMORA-CHINCHIPE: Nangaritza, Cordillera del Condor, Shaime, en la unión de los Ríos Nangaritza y Numpatakaime, 1000 m, 4²0’ S, 7840’W, 7 Dec. 1990, Palacios 6611 (MO, QCNE). PERU. AMAZONAS: Bagua, Imaza, Kampaensa, 320 m, 4 ${ }^{\circ} 55^{\prime}$ 'S, 78 $7{ }^{\circ} 19^{\prime} \mathrm{W}, 20$ Oct. 1995, Vasquez et al. 20344 (MO); $320 \mathrm{~m}$, $4^{\circ} 55^{\prime} \mathrm{S}, 78^{\circ} 19^{\prime} \mathrm{W}, 22$ Oct. 1995, Vasquez et al. 20395 (MO, NY); Condorcanqui, E1 Cenepa, Mamayaque, Río Cenepa, Sáasa, 400 m, 4³7’08"S, 78¹3'46"W, 6 Feb. 1997, Vásquez et al. 22384 (MO); Río Cenepa, Bashuchunuk, Monte y chacra al lado Huampami, 17 Jan. 1973, Kayap 139 (MO); Alrededor Kusu, Río Numpatkin, Monte y chacra al lado de Kusu, 335-400 m, 10 Mar. 1973, Kayap 515 (MO, US); vic. Kusu, Río Numpatkin, 1100-1300 m, Ancuash 74 (MO); Río Santiago valley, ca. $65 \mathrm{~km} \mathrm{~N}$ de Pinglo, 2-3 km behind Caterpiza, 200 m, 29 Jan. 1980, Huashikat 1867 (MO); Huampami, $5 \mathrm{~km}$ E of Chavéz Valdivia, 78³0'S, 4³0'S, 200-250 $\mathrm{m}$, front of Chigkan entsa, Ancuash 1308 (MO), 200-300 m, Ancuash 1288 (MO), 240260 m, Kayap 1359(MO); "La Banda”, Berlin 185 (MO); S of Huampami trail to house of Theodora, S of Río Cenepa, 800-850 m, Berlin 1665 (MO); trail $\mathrm{N}$ of Cenepa toward headwaters of Kayamas Creek, 180-240 m, Berlin 1744 (MO); Q Shimpunts, 180-300 m, Ancuash 13 (MO); Wampusik entsa, 180-300 
m, Ancuash 725 (MO).

Rhodospatha piushaduka Croat, sp. nov. Type: Perú. Amazonas: Condorcanqui, Río Cenepa, Quebrada Chichijam entsa, Chacramonte, 400 m, 24 May 1973, E. Ancuash 430 (holotype, MO-2253372; isotypes K, USM). Fig. 12c.

Planta terrestris, ad $1 \mathrm{~m}$; internodia ca. $1.5 \mathrm{~cm}$ longa, $1.5 \mathrm{~cm}$ diam.; petioli $58-68.5$ cm longi, vaginati $12-19 \mathrm{~cm}$; laminae oblongo-ellipticae, $49-63 \mathrm{~cm}$ longae, $22-28 \mathrm{~cm}$ latae; nervis primariis lateralibus ca. 20 utroque; pedunculus 17-19.5 cm longus, 6-7 mm diam.; spatha alba, 14-15.5 cm longa; spadice $11.5-14.5 \mathrm{~cm}$ longus, $1-1.5 \mathrm{~cm}$ latus; pistilla $1.1-1.5 \mathrm{~mm}$ diam.

Terrestrial herb to $1 \mathrm{~m}$ tall; internodes ca. $1.5 \times 1.5 \mathrm{~cm}$, drying tan, moderately smooth. Petioles 58-68.5 cm long, 1.2 times longer than the blade, grayish green, drying finely, regularly and conspicuously ridged, densely speckled with pale, short-lineate raphide cells, finely granular on magnification, sheathed $12-19 \mathrm{~cm}$ from the base of the blade; geniculum 3.2-4.5 cm long, drying sharply sulcate, darker the the remainder of the petiole; blades oblongelliptic, $49-63 \times 22-28 \mathrm{~cm}, 2-2.5$ times longer than wide, broadest at about the middle, 0.8 times as long as the petioles, inequilateral, one side $2-3 \mathrm{~cm}$ wider than the other, obtuse to rounded and acuminate at apex, obtuse and weakly attenuate at base, both apex and base +/- equal, +/- matte above, semiglossy below, drying gray-green above, reddish brown below; midrib narrowly sunken and concolorous above, drying bluntly acute and tan below; primary lateral veins ca. 20 per side, $1.7-3.3 \mathrm{~cm}$ apart, arising at an acute angle, then spreading at $65^{\circ}-80^{\circ}$ angle in a broad curve to the margin, then broadly curved in the outer $1 / 3$, minutely granular on magnification; interprimary veins usually not present, sometimes 1; minor veins 10-14, nearly identical, sometimes drying undulate; crossveins straight or oblique, obscure but dense, +/- evenly scattered across the blade; upper surface densely granular on 

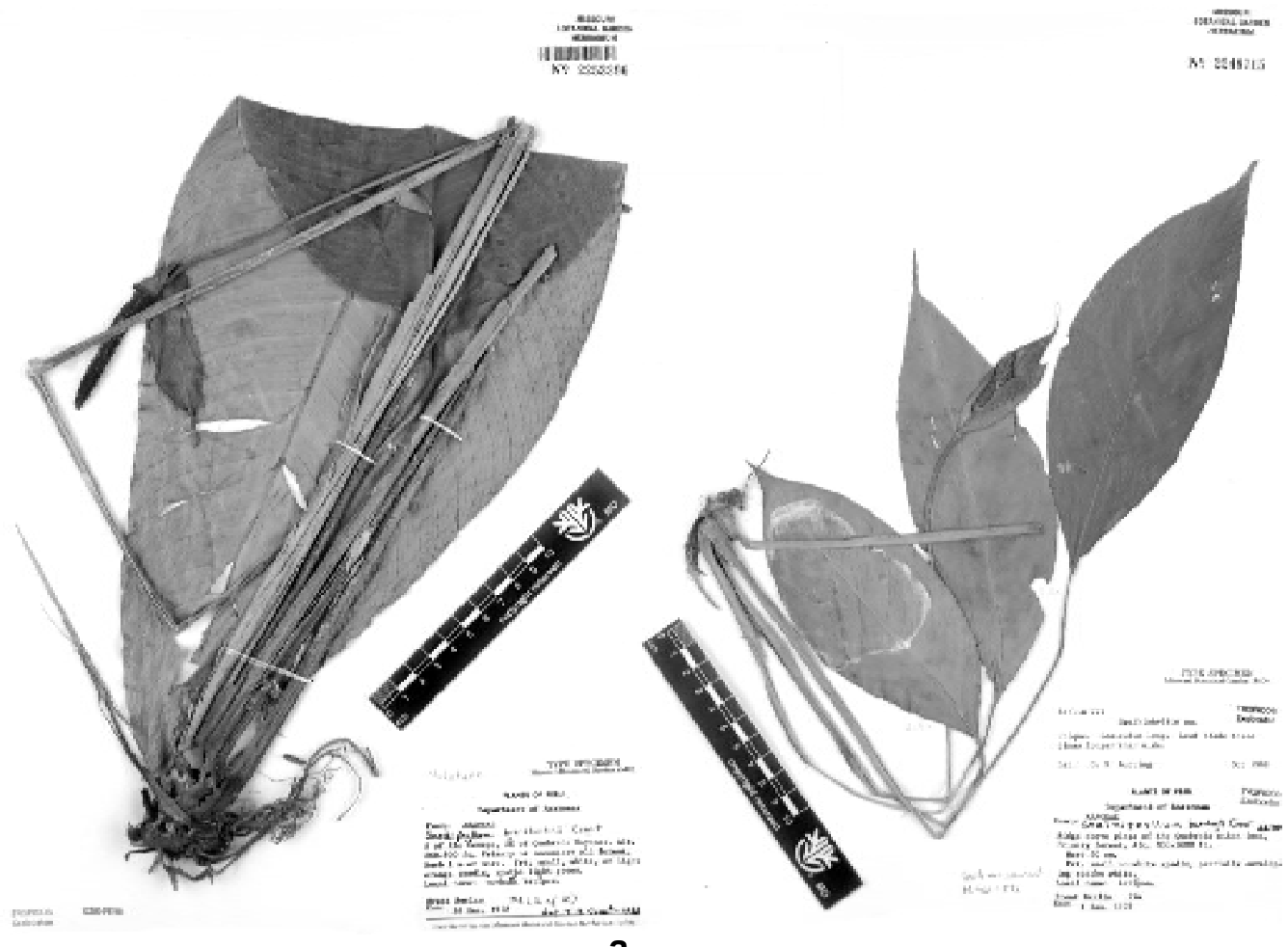

a
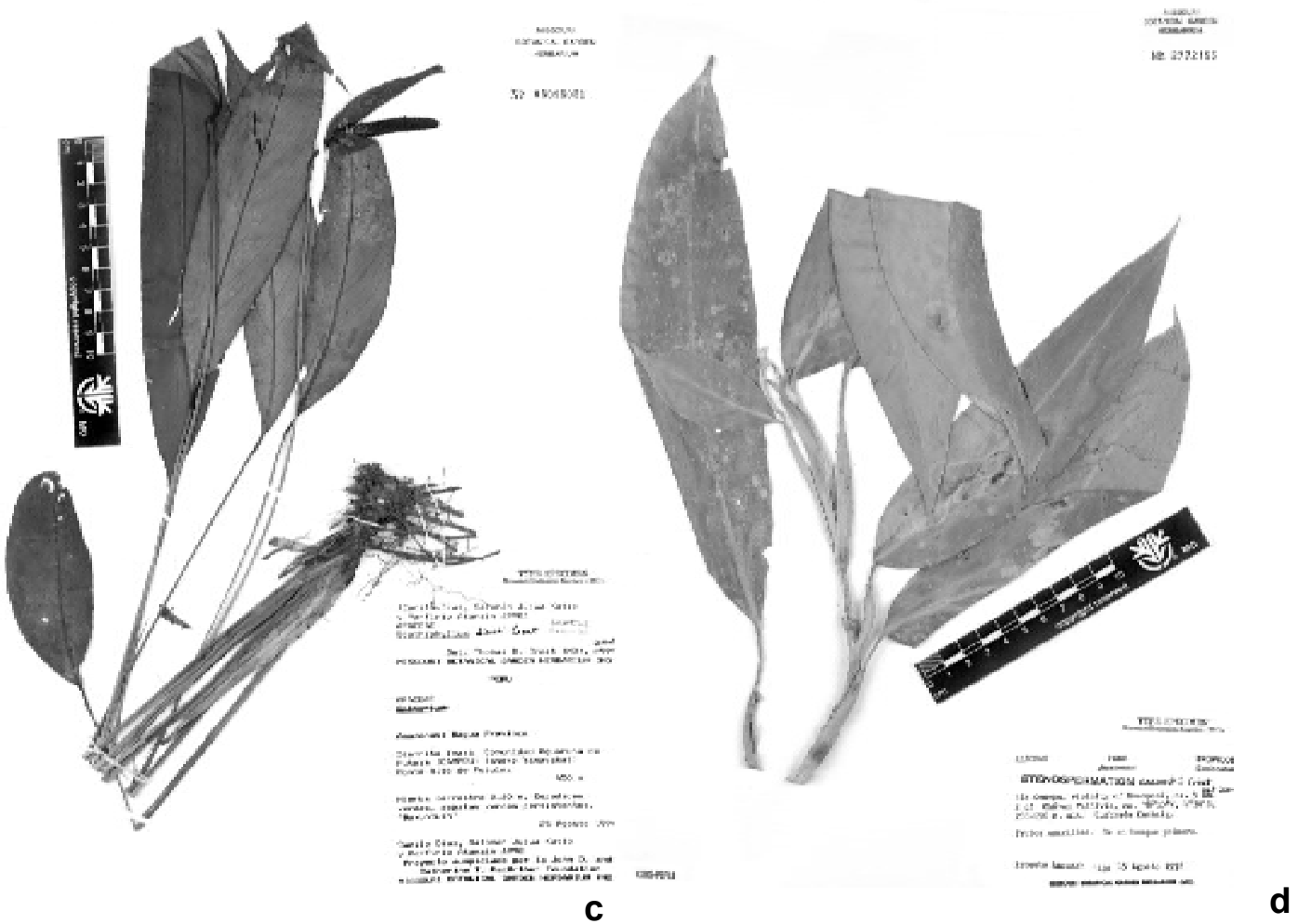

Figure 13 - a. Spathiphyllum brent-berlinii Croat. Type specimen. (Berlin 741); b. Spathiphyllum buntingianum Croat. Type specimen. (Berlin 774); c. Spathiphyllum diazii Croat. Type specimen. (Díaz et al. 6998); d. Stenospermation ancuashii Croat. Type specimen. (Ancuash 1491) 
magnification, the lower surface densely and minutely reddish granular with the background appearing to be whitish-punctate; Inflorescence erect; peduncle $17-19.5 \mathrm{~cm} \times$ 6-7 mm, drying tan; spathe white, 14-15.5 $\mathrm{cm}$ long, moderately coriaceous, drying light reddish brown, acuminate at apex; spadix $11.5-14.5 \mathrm{~cm}$ long at anthesis, $1-1.5 \mathrm{~cm}$ wide, to $16 \mathrm{~cm}$ long post-anthesis; pistils at first 4-sided and rhombic, becoming irregularly 5-6 sided, 1.1-1.5 mm diam.; style light brown, densely and minutely granular on magnification; stigma elliptic, moderately raised with a narrow brown margin, 0.8-0.9 $\times 0.3-0.4 \mathrm{~mm}$, drying dark brown, sulcate medially. Infructescence not seen.

Rhodospatha piushaduka is endemic to Amazonas Department, Perú in the vicinity of the Río Cenepa at ca. $400 \mathrm{~m}$ in Tropical moist forest (T-mf) and Tropical wet forest (T-wf) life zones.

The species is characterized by terrestrial habit, low stature (ca. $1 \mathrm{~m}$ tall), prominently striate dried petioles which are longer than the blades and densely pale-speckled, and reddish brown-drying blades with widely spaced pale-drying primary lateral veins appearing disconnected to the midrib. The reddish brown-drying spathe is also characteristic.

Rhodospatha piushaduka is similar to $R$. mukuntachia Croat in that they both are terrestrial with short internodes often totally obscured by the petiole bases, and petiole sheathes that do not extend to the apex. However, R. piushaduka has stems that dry pale creamy yellow (dark brown in $R$. mukuntachia), petioles that are weakly fibrous along the margins, never deciduous, drying light yellow-green and densely speckled (petioles markedly weathering into fibers or totally decidous, drying mostly medium to dark brown, not obviously speckled in $R$. mukuntachia), and a light reddish browndrying spathe (dark brown drying spathe in R. mukuntachia).

The species is locally called "piushaduka" (hence the epithet) by the local Aguaruna Indians. 
Spathiphyllum barbourii Croat, sp. nov. Type: Perú. Amazonas: Bagua, along rd. from Chiriaco to Puente Venezuela, $43 \mathrm{~km}$ NE of Chiriaco, 320-730 m, 5 Nov. 1978, $P$. Barbour 4460 (holotype, MO-2800691). Fig. $12 \mathrm{~d}$.

Planta terrestris; internodia brevia; petioli $12-21 \mathrm{~cm}$ longi; laminae anguste lanceolatae vel oblanceolatae vel oblongaellipticae, 10-17 cm longae, 2.1-4.1 cm latae; nervis primariis lateralibus 6-9 utroque; pedunculus 20-32 cm longus; spatha viridis vel alba, 5-7.2 cm longa; spadice viridis vel albus, $1.8-3 \mathrm{~cm}$ longus, stipitatus $1-1.8 \mathrm{~cm}$.

Terrestrial; internodes short; Leaves erect-spreading with petioles $12-21 \mathrm{~cm}$ long, drying 1-2 mm diam., narrowly and deeply sulcate at and below geniculum, sheathed, drying medium to light brown; sheath extending $4 / 10$ to $2 / 3$ the length of the petiole, usually prominently decurrent, margins sometimes breaking off; blades narrowly lanceolate to oblanceolate or oblong-elliptic, $10-17 \times 2.1-4.1 \mathrm{~cm}$, sometimes inequilateral (one side up to $6 \mathrm{~mm}$ wider), gradually acuminate, (acumen 1.5-2.5 cm long), cuneate (often times one margin of the blade becomes folded under on drying, making the base appear inequilateral); upper surface drying dark brown, sometimes tinged with gray; lower surface drying pale yellow-brown, obscurely pale punctate at higher magnifications; midrib flat to broadly convex above, concolorous, rounded, sometimes narrowly rounded, concolorous to slightly darker below; primary lateral veins 6-9 per side, scarcely more conspicuous than interprimary veins. Inflorescence with peduncle $20-32 \mathrm{~cm}$ long; spathe reflexedspreading to spreading, green or white, lanceolate, 5-7.2 cm long, drying 1-1.7 cm diam. at widest point in lower $1 / 3$, apex gradually long-acuminate; spadix green to white, cylindrical, stipitate (stipe $1.0-1.8 \mathrm{~cm}$ long), 1.8-3 cm long, drying 4-5 mm diam. Flowers $2.5-3 \times 2.7-2.8 \mathrm{~mm}$; lateral tepals 1.1-1.8 mm wide.

Spathiphyllum barbourii ranges from southern Ecuador (Zamora-Chinchipe) to northern Peru (Amazonas Department, Bagua Province) at 730-900 $\mathrm{m}$ in Tropical rain forest (T-rf) to Tropical wet forest (T-wf) life zones. It is characterized by narrowly lanceolate to oblong-elliptic to narrowly oblanceolate blades drying dark brown above and yellowish brown below, as well as by a narrowly lanceolate white to green, long-acuminate spathe and stipitate white to green spadix. It is most closely related $S$. minor Bunting which shares similarly shaped blades and a slenderly stipitate spadix. That species differs in having blades that are more broadly elliptic and dry dark olive-green to gray-green on the upper surface and grayish yellow-green on lower surface. In addition, S. minor has a purplebrown spadix, while $S$. barbourii has a spadix that is initially white, then turning to green.

The species is named in honor of Philip Barbour, formerly a student at the Missouri Botanical Garden, who collected the type specimen during his work in the La Peca region east of Bagua. Barbour is finishing a Ph.D program at Mississippi State University. Paratypes: ECUADOR. ZAMORACHINCHIPE: Cordillera del Condor, hills behind Campamento Miazi along Río Nangaritza, 4 ${ }^{\circ} 16^{\prime}$ 'S, $78^{\circ} 40^{\prime} \mathrm{W}, 900-1200 \mathrm{~m}$, 18 Feb. 1994, van der Werff et al. 13247 (MO); Nangaritza, Miazi, behind military camp, 416'S, 78 42' W, 900-1000 m, 21 Oct. 1991, Palacios et al. 8576 (CAS, COL, MO, QCNE, US). PERU. AMAZONAS: E1 Almendro, along creek and on sandstone, 5'14'40"S, 78²1'24"W, 430 m, 9 Mar. 1998, van der Werff et al. 14543 (IBE, K, MO); Bagua, Imaza, Putuim-Shimutaz, $5^{\circ} 03^{\prime} 20^{\prime \prime} \mathrm{S}$, 78²0’23"W, 550 m, 21 June 1996, Vásquez et al. 21317 (AAU, F, MO); Tayu Mujaji, Wawas, $5^{\circ} 15^{\prime} 25^{\prime \prime} \mathrm{S}, 78^{\circ} 21^{\prime} 41^{\prime \prime W}, 800 \mathrm{~m}, 23$ Oct. 1997, Rojas et al. 382 (MO, WU); 40$43 \mathrm{~km}$ NE of Chiriaco, 5 Nov. 1978, Barbour 4460 (MO); Yamayakat, Imaza, Aguaruna de Putuim (CAMPOU), anexo Yamayakat, 450 m, 25 Aug. 1994, Díaz et al. 6998 (K, MO, US). 
Spathiphyllum brent-berlinii Croat, sp. nov. Type: Perú. Amazonas: S of Río Cenepa, SE of Quebrada Kayamas, 800-900 m, 28 Dec. 1986, B. Berlin 741 (holotype, MO-2253396; isotypes IBE, K, USM). Fig. 13a.

Planta terrestris, 40-100(200) cm; internodia 1.5-2.5 cm diam.; petioli $25-86 \mathrm{~cm}$ longi, vaginati $19.3-36.5 \mathrm{~cm}$; laminae anguste ovatae vel ovatae-ellipticae, (18)28-43 cm longae, (7.5)12-24 cm latae; nervis primariis lateralibus 14-20 utroque; pedunculus 46-63 cm longus; spatha alba vel viridis, $8-13.2 \mathrm{~cm}$ longa, 2.7-3.5 cm lata; spadice luteus vel aurantiacus, (4.2)5.2-6.7 cm longus, stipitatus 6-10 mm, pistila 3-locularia; ovulis 2 per loculum; bacca alba.

Terrestrial herb (30)50-100(200) cm tall; rhizomes short, creeping; internodes short, $1.5-2.5 \mathrm{~cm}$ diam. Petioles $25-86 \mathrm{~cm}$ long, sheathed $19.3-36.5 \mathrm{~cm}, 0.42-0.67$ its length, about as long at the blades or to 2 times longer than blade, drying dark brown to light yellow-brown, weakly glossy; geniculum 1.5-2.7 cm long, drying darker than the the petiole shaft; blades narrowly ovate to ovate-elliptic, (18)28.7-43 × (7.5)12$24 \mathrm{~cm}, 1.4-2.1$ times longer than wide, equalling or up to 1.8 times longer than the peduncle, one side $0.8-2.3 \mathrm{~cm}$ wider than the other side, abruptly acuminate at apex, acute to rounded and attenuate at the base, drying gray above, moderately paler and yellowbrown below; midrib weakly sunken and concolorous above on drying, convex to obtusely angular or quadrangular and slightly darker, finely ribbed below; primary lateral veins 14-20 per side, arising at an acute angle then spreading at $45-70^{\circ}$ angle, drying scarcely distinguishable on the upper surface, narrowly raised and darker or rarely paler than surface below, moderately more conspicuous than the interprimary veins, the latter 1-2 between each pair of primary lateral veins, alternating with an increasingly fainter series of minor veins; minor veins close, weakly raised, paler than the surface; Inflorescence with peduncle $46-63 \mathrm{~cm}$ long; spathe white becoming lime-green, $8-13.2 \times 2.7-3.5 \mathrm{~cm}$,
2.2-5.2 times longer than wide, caudateacuminate at apex; spadix yellow to light orange or coral-colored, or golden-yellow, eventually green, (4.2)5.2-6.7 cm long, drying $0.8 \mathrm{~cm}$ diam., 5-10 times longer than wide, stipitate $6-10 \mathrm{~mm}$; pistils $2.6 \mathrm{~mm}$ long, ovary $2.4 \times 1.5-1.8 \mathrm{~mm}$; style $0.8-1 \mathrm{~mm}$ diam., drying blackened; stigma protruding to 0.6 $\mathrm{mm}$ above style on drying, $0.5 \mathrm{~mm}$ diam.; locules 3 per ovary; ovules basal, 2 per locule; ovules $0.3 \times 0.4 \mathrm{~mm}$; funicle $0.6 \mathrm{~mm}$ long; berries white.

Local Aguaruna names: diusha, nunkaña katípas, puisha duka, piúsa, shitapach mukuntach.

The species is known only from Amazonas Department, Peru, ranging from 213$850 \mathrm{~m}$ elevation in Tropical wet forest (T-wf) and Premontane wet forest (P-wf) life zones.

Spathiphyllum brent-berlinii is recognized by yellowish drying petioles, more or less ovate, yellowish-brown drying blades on the lower surface, the prominent, close primary lateral veins, the usually yellow to orange spadix, white spathe, and white fruits.

Spathiphyllum brent-berlinii is closest to $S$. juninense K. Krause, but differs from that species having blades that dry yellowbrown on the lower surface, and more prominent primary lateral veins, as well as considerably narrower pistils. The dried material of the pistils of $S$. brent-berlinii, like $S$. juninense, has ovaries that are densely packed on the entire outer portion with a dense layer of trichoschlereids, most likely to prevent predation of the berries.

Some collections (Rodriguez \& Rodríguez 898, Diaz et al. 6975, 7105, 7705, Vasquez et al. 19571, 21427, 21571, and Kayap 302) differ from typical specimens of of $S$. brent-berlinii in having the lower blade surface darker brown or more green, but otherwise probably belong with this species as well.

The species is named in honor of Dr. Brent Berlin, University of Georgia, who collected the type specimen during his 


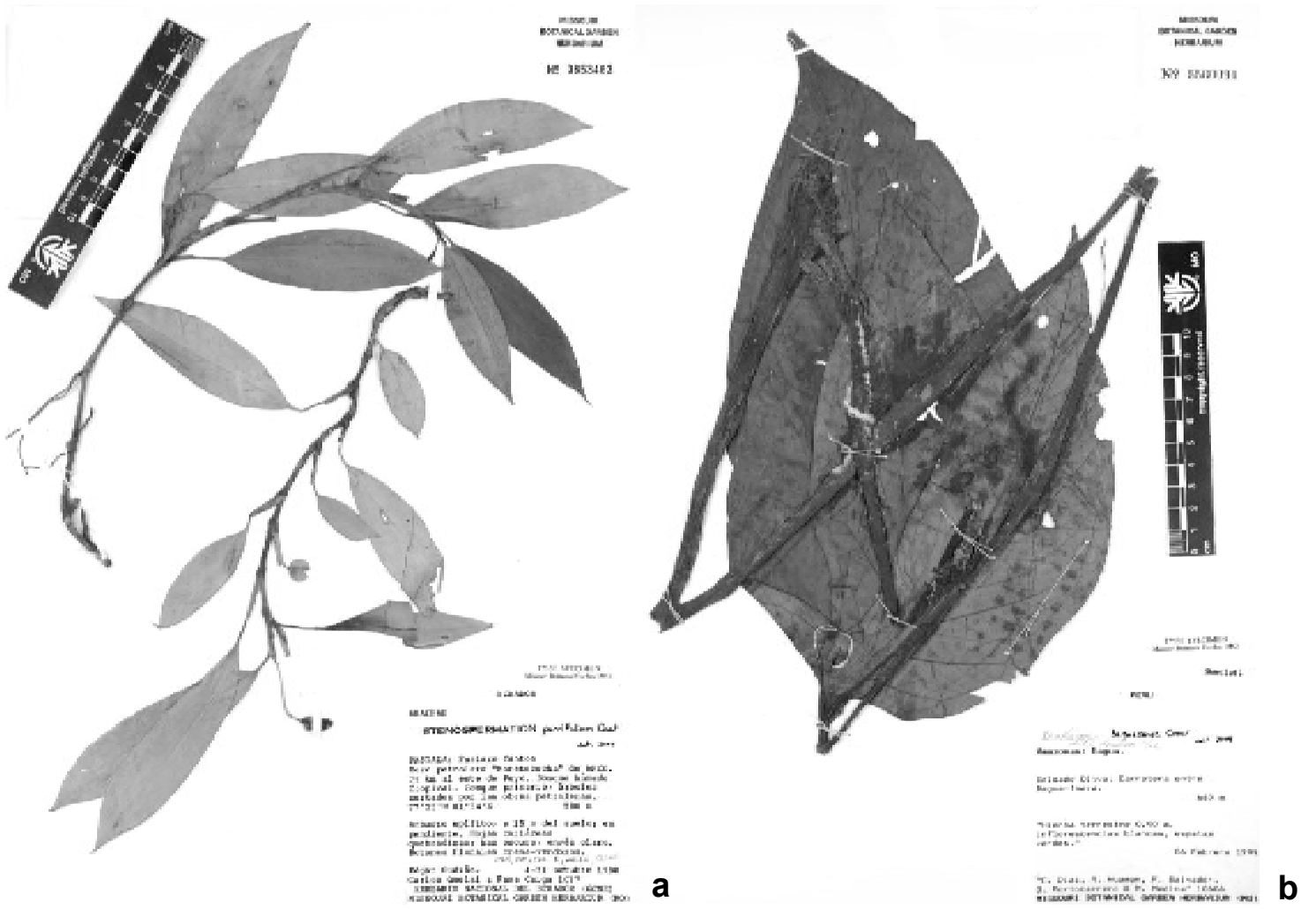

Figure 14 - a. Stenospermation parvum Croat \& A.P. Gómez. Type specimen. (Gudiño et al. 1077); b. Xanthosoma baguense Croat. Type specimen. (Díaz et al. 10606)

anthropological studies with the Aguaruna Indian tribe in the Río Cenepa and Río Santiago region of northern Peru. Berlin and his collaborators collected many new species of Araceae in this region.

Paratypes: PERU. AMAZONAS: Quebrada Sasa, Río Cenepa, 260 m, 2 June 1973, Ancuash 511 (GH, MO); Bagua, Imaza, Yamayakat, Quebrada Kusú, transect 2 x 500 $\mathrm{m}, 5^{\circ} 03^{\prime} 20^{\prime \prime} \mathrm{S}, 78^{\circ} 20^{\prime} 23^{\prime \prime} \mathrm{W}, 380 \mathrm{~m}, 1$ Nov. 1996, Vásquez et al. 21427 (MO); 21571 (MO); 370 m, 22 July 1994, Díaz et al. 6975 (MO); 45'ㅅ, 78 ${ }^{\circ} 19^{\prime} \mathrm{W}, 350-450$ m, 7 June 1996, Rodríguez \& Rodríguez 898 (MO); Kampaentza, Río Marañón, near mouth of Quebrada Shimutaz, Aguaruna Kampaentza, $10^{\circ} \mathrm{N}, 350$ m, 7 Sep. 1994, Díaz et al. 7105 (GB, MO, NY, RSA); Shimutáz, along stream 2 hrs. from its mouth at Río Marañon), 500 600 m, 22 Oct. 1995, Díaz et al. 7705 (MO); Yamayakat, Camino hacia Temashnum, 300480 m, 17 Aug. 1996, Díaz et al. 7901 (MO);
Yamayakat, Quebrada Kusu-Chapi, Río Marañon, area permanente $500 \times 500 \mathrm{~m}$, parcela "E", 455'S, 78¹9'W, 550 m, Feb. 1995, Vasquez et al. 19571 (MO); Condorcanqui, Huampami, Río Cenepa, 428'S, 78¹0'W, 198-213 m, 22 Aug. 1976, Boster 80 (MO); 240-275 m, Quebrada Wampusik entsa, 5 Aug. 1974, Ancuash 739 (MO, U); vic. of Huampami. ca. $5 \mathrm{~km}$ E of Chávez Valdivia, camino de Chigkan entsa, $4^{\circ} 30^{\prime} \mathrm{S}, 78^{\circ} 30^{\prime} \mathrm{W}$, 200-250 m, 1 Aug. 1978, Kujikat 95 (MO); 221 (MO); 430’'S, 78³8’ W, 24 July 1978, Ancuash 1076 (MO); 1234 (MO); 7 Aug. 1978, Ancuash 1319 (MO); 11 Aug. 1978, Ancuash 1411 (MO); 335 m, ridge E of Cinkan, 12 km N of Río Cenepa, 11 Oct. 1972, Berlin 245 (MO); above and around Huampami, 220-270 m, 21 Nov. 1972, Berlin 321 (MO); trailside E of Huampami, 1 days walk to Shaim, along creek flowing into Nahim, which runs into Huampami Creek, 550-600 m, 27 Nov. 1972, Berlin 390 (MO); 
240-275 m, SW of Kayamas, 28 Dec. 1972, Berlin 741 (K, MO, USM); ridge above Cikan Ece Creek, 230 m, 16 July 1974, Berlin 1616 (MO); trail $\mathrm{N}$ of Cenepa, toward headwaters of Kayamas Creek, 180-240 m, 18 July 1974, Berlin 1725 (MO); monte al lado de Huampami, 31 Jan. 1973, Kayap 302 (MO); Etseketai, Río Cenepa, 260 m, 31 May 1973, Kayap 865 (MO); Río Cenepa, Lugar, 180 m, 15 June 1973, Kayap 969 (G, MO, NY); Allado de Cenepa, 230 m, 22 July 1974, Kayap 1270 (MO); 240-260 m, 26 July 1974, Kayap 1314 (MO); monte al lado de Huampami, 240-260 m, 29 July 1974, Kayap 1336 (MO); 1345 (MO); Río Santiago valley, Quebrada $2-3 \mathrm{~km}$ behind Caterpiza, $3^{\circ} 50$ 'S, $77^{\circ} 40^{\prime} \mathrm{W}, 180 \mathrm{~m}, 8$ Feb. 1980, Tunqui 775 (MO); $1 \mathrm{~km}$ behind Caterpiza, E of Quebrada Caterpiza, Río Santiago, 180 m, 20 Nov. 1979, Huashikat 1351 (MO); 200 m, 19 Dec. 1979, Huashikat 1587 (MO); 200 m, 12 Sep. 1979, Huashikat 593 (MO); $2 \mathrm{~km}$ behind Caterpiza, E of Quebrada Caterpiza, Río Santiago, ca. $65 \mathrm{~km} \mathrm{~N}$ de Pinglo, $200 \mathrm{~m}, 5$ Mar. 1980, Huashikat 2200 (MO).

Spathiphyllum buntingianum Croat, sp. nov. Type: Perú. Amazonas: ridge above playa of Quebrada Cikan Inci, 240-300 m, 1 Jan. 1973, B. Berlin 774 (holotype, MO-2249715).

Fig. 13b.

Planta terrestris; internodia brevia, 0.8 mm diam.; petioli 21-33 cm longi; laminae ellipticae, $16-21 \mathrm{~cm}$ longae, $6.3-7 \mathrm{~cm}$ latae; nervis primariis lateralibus 8-9 utroque; pedunculus $35 \mathrm{~cm}$ longus, $2 \mathrm{~mm}$ diam. in sicco; spatha $7.2 \mathrm{~cm}$ longa, alba; spadice 3 cm longus, albus.

Terrestrial, $50 \mathrm{~cm}$ tall; internodes short, $8 \mathrm{~mm}$ diam. Petioles $21-33 \mathrm{~cm}$ long, drying greenish yellow-brown, matte, finely striate, sheathed $9.5-14.5 \mathrm{~cm}, 0.40-0.43$ its length; geniculum $2.2-3.5 \mathrm{~cm}$ long, $1.5 \mathrm{~mm}$ diam., appearing remote, slightly darker than the petiole; blades elliptic, $16-21 \times 6.3-7 \mathrm{~cm}$, 25.-3.2 times longer than wide, abruptly to grandually long-acuminate at apex (acumen to $2 \mathrm{~cm}$ long), attenuate at the base, medium green and semiglossy above, moderately paler and semiglossy to matte below, drying dark brown above, moderately paler and yellowbrown below, slightly inequilateral, one side 3-6 mm wider than the other; midrib convex concolorous (slightly paler toward the base) and finely striate above; primary lateral veins $8-9$ per side, arising at $40-45^{\circ}$ angle, drying paler than the surface below; interprimary veins 3-4 between each pair of primary lateral veins, these interconnected by oblique or transverse raised cross-veins. Inflorescence with peduncle $35 \mathrm{~cm}$ long, drying $2 \mathrm{~mm}$ diam., drying medium yellowish brown; spathe white, $7.2 \mathrm{~cm}$ long, ovatelanceolate, narrowly long-acuminate, drying yellowish red-brown, with rather prominent longitudinal veins and oblique cross-veins; spadix stipitate $6 \mathrm{~mm}$ long, the spadix proper $3 \mathrm{~cm} \times 6 \mathrm{~mm}$. Flowers 4-5 per spiral, drying dark brown, $2 \mathrm{~mm}$ diam., the tepals light yellow-brown, free or united, especially at apex but easily breaking apart, 1-2 $\mathrm{mm}$ wide, turned in over the pistils, the inner margins minutely undulate-fringed; pistils $1.8 \mathrm{~mm}$ diam. on drying; style weakly raised, 3-sided, each division weakly sulcate; ovary 3 -locular; ovules 1 per locule, basal, $0.1 \times 0.18 \mathrm{~mm}$.

Local Aguaruna name: katípas.

Spathiphyllum buntingianum is known only from the type specimen in Amazonas Department at 240-300 m elevation in the Tropical wet forest (T-wf) life zone.

The species is distinguished by small elliptic blades, long and remote geniculum and broad, clasping white spathes surrounding a short, cylindrical white spadix. The species dries the same color as $S$. brent-berlinii and has similar venation, but that species has much larger leaves, and a typical basal geniculum.

The species is distinguished from other small-bladed species in the region by having elliptic blades which dry medium yellowgreen on the lower surface, rather than oblongelliptic blades that dry gray-green to dark brown or yellow-brown on lower surface. Moreover, other species in the area, including $S$. barbourii and S. minor G. S. Bunting, do 
not have the geniculum remote from the base of the blade.

The species is named in honor of George Bunting, a reknown aroid systematist, who published (1960) the first revision of the genus since Engler.

Spathiphyllum diazii Croat, sp. nov. Type: Peru. Amazonas: Bagua, Imaza, Aguaruna de Putuim (CAMPOU), Yamayakat, Monte Alto de Putuim, 450 m, 25 Aug. 1994, C. Diaz, S. J. Katip \& P. Atamain 6998 (holotype MO05095051; isotype, USM). Fig. 13c.

Planta terrestris; internodia brevia, $1-$ $1.5 \mathrm{~cm}$ diam.; petioli $28-30 \mathrm{~cm}$ longi; $1 \mathrm{~mm}$ diam. in sicco; laminae 19-24.5 cm longae, $3.8-4.4 \mathrm{~cm}$ latae, oblongo-lanceolatae; nervis primariis lateralibus 6-8 utroque; pedunculus $27-44 \mathrm{~cm}$ longus; spatha lanceolata, 6-8 cm longa, $1.3-1.7 \mathrm{~cm}$ lata, alba vel viridis; spadice viridis vel albus, $4.5 \mathrm{~cm}$ longus, $5 \mathrm{~mm}$ diam., stipitatus 6-8 $\mathrm{mm}$.

Terrestrial; internodes $1-1.5 \mathrm{~cm}$ diam. Petioles $28-30 \mathrm{~cm}$ long, slender, drying $1 \mathrm{~mm}$ diam., dark yellow-brown, sheathed to the middle or slightly below middle, sheath in part breaking free; geniculum $0.7-1 \mathrm{~cm}$, drying about the same color as the petioles; blades 19-24.5 × 3.8-4.4 cm, oblong-lanceolate, oblique and inequilateral, (one side $6 \mathrm{~mm}$ wider) weakly falcate, gradually longacuminate at apex, narrowly acute at base, drying dark brown above, scarcely paler and dark yellow-brown below; midrib flat, drying slightly darker above, narrowly raised, drying moderately darker below; primary lateral veins $6-8$ per side, $+/$ - equaling interprimary veins, arising at $25-30^{\circ}$ angle, weakly arcuate to the margins; minor veins moderately obscure. Inflorescence held somewhat lower than leaves; peduncle $27-44 \mathrm{~cm}$ long, drying medium yellow-brown, somewhat flattened, $1.5 \mathrm{~mm}$ wide; spathe lanceolate, $6-8 \times 1.3-$ $1.7 \mathrm{~cm}$, white to green; spadix green to white, $4.5 \times 0,5 \mathrm{~cm}$, stipe $6-8 \mathrm{~mm}$ long; perianth segments free; pistils cylindricalobpyramidal, rounded at apex; ovules 2locular; locules 1-ovulate, the entire periphery of the ovary embedded with long trichoschlereids. Infructescence with berries drying $3 \times 2 \mathrm{~mm}$; seeds light brown, acutely 3-4-ribbed around the circumference, $1.5 \mathrm{~mm}$ wide, $1 \mathrm{~mm}$ thick.

Spathiphyllum diazii is known only from Amazonas Department, Bagua Province at 700-750 m elevation in the Premontane wet forest (P-wf) life zone.

One collection (van der Werff et al. 14543) from Amazonas at Quebrada El Almendro, 430 m elevation, may also be this species, but it has proportionately smaller and broader leaf blades and spathes.

Spathiphyllum diazii is most similar to $S$. gracilis Bunting in that they both have longer than broad blades more than $17 \mathrm{~cm}$ long. However, S. diazii has weakly bicolorous blades drying dark yellow-brown on the lower surface (prominently bicolorous drying pale yellow-brown on the lower surface in $S$. gracilis), and petioles sheathed below the middle, usually in the lower $1 / 3$ of the blade (petioles sheathed to above the middle in $S$. gracilis).

The species is named in honor of Camilo Diaz, Peruvian botanist, who collected extensively in the Río Cenepa region and collected the type specimen.

Paratypes: PERU. AMAZONAS: Bagua, Imaza, Aguaruna Putuim, anexo Yamayakat, $240^{\circ}$ SW of Putuim, 700 m, 22 Sep. 1994, Diaz et al. 7198 (MO, USM); $285^{\circ} \mathrm{SW}$ of Yamaykat, 700-750 m, 23 Jan. 1996, Diaz et al. $7773 A$ (MO, USM); trail from Putuim to Shimutaz, 503'20"S, 78 $20^{\prime} 23^{\prime \prime} \mathrm{W}, 550 \mathrm{~m}, 21$ June 1996, Vasquez et al. 21317 (MO).

Stenospermation ancuashii Croat, sp. nov. Type: Perú. Amazonas: Río Cenepa, vic. of Huampami, ca. $5 \mathrm{~km}$ E of Chávez Valdivia, Quebrada Kachaig, ca. 78 $30^{\prime} \mathrm{W}, 4^{\circ} 30^{\prime}$ 'S, 200-250 m, 15 Aug. 1978, E. Ancuash 1491 (holotype, MO-2772155). Fig. 13d.

Planta terrestris; internodia $1-2.6 \mathrm{~cm}$ longa, 5-9 mm diam. in sicco, petiolus 5-8.8 $\mathrm{cm}$ long, lamina lanceolata ad anguste oblonga-elliptica ad anguste oblanceolata, 18-27 cm longa, 3.1-6.5 cm lata, nervis 
primaries lateralibus obscures; pedunculus $8.5-9.5 \mathrm{~cm}$ longa, $1.5 \mathrm{~mm}$ diam. in sicco; spadice stipitis 5-6 mm, 2.6-3.2 cm longa, 3-5 mm lata.

Apparently a terrestrial herb; internodes 1-2.6 cm long, drying 5-9 $\mathrm{mm}$ diam., pale yellow-brown, semiglossy, finely, deeply and acutely ridged. Petioles $5-8.8 \mathrm{~cm}$ long, sheathed 0.58-0.76 times its length, drying pale yellow-brown, finely striate-ridged, the sheath 4-7 mm wide, erect, ending acute to weakly rounded at apex, not markedly freeending, free portion of petiole $0.6-2.6 \mathrm{~cm}$ long, drying deeply sulcate; blades lanceolate to narrowly oblong-elliptic to narrowly oblanceolate, $18-27 \times 3.1-6.5 \mathrm{~cm}, 3.9-4.6$ times longer than wide, 3.2-3.6 times longer than petioles; midrib weakly raised and concolorous above, weakly raised, broad and more brown, slightly darker below; primary lateral veins not obvious or not present; upper surface with the veins 3-4.5 mm apart, weakly raised, the interveinal areas relatively featureless at magnifications of $15 \times$, but densely short pale-lineate with cellular inclusions of differing lengths; lower surface with minor veins equally distant, weakly raised on magnification, the intervening area with fine, irregular ridges (presumably visible trichoschlereids) and sometimes also granuliforme to warty-granular with few linear short whitish cellular inclusions. Inflorescence short, held well below the leaves; peduncle $8.5-9.5 \mathrm{~cm}$ long, drying 1.5 $\mathrm{mm}$ diam., yellow-brown; spadix stipitate 5$6 \mathrm{~mm}$ (stipe 1-1.5 mm diam on drying), 2.6$3.2 \mathrm{~cm}$ long (excluding stipe), 3-5 mm diam. Flowers irregularly 4-6 sided, drying light yellow-brown, matte; stigma $0.15-0.35 \times 0.1-$ $0.15 \mathrm{~mm}$, medially sunken.

Local Aguaruna name: kuwish.

This species is named in honor of Ernesto Ancuash, an Aguaruna Indian plant collector who collected the type specimen as part of Brent Berlin's ethnobotanical research expeditions to the Alto Marañón river region of northern Perú.

Paratype: PERU. AMAZONAS: Río Cenepa, vic. of Huampami, ca. $5 \mathrm{~km} \mathrm{E}$ of Chávez Valdivia, Quebrada Aintami, al lado de Chigkan entsa, ca. 78³0'W, 4³0'S, 200-250 m, 17 Aug. 1978, Kujikat 430 (MO). 
